MAURO ENRIQUE DE SOUZA MUÑOZ

\title{
DESENVOLVIMENTO ARTIFICIAL AUTÔNOMO DE UM GRAFO SENSÓRIO-MOTOR AUTO-ORGANIZÁVEL
}

\author{
Tese apresentada à Escola Politécnica da \\ Universidade de São Paulo para obtenção do \\ Título de Doutor em Ciências.
}


MAURO ENRIQUE DE SOUZA MUÑOZ

\section{DESENVOLVIMENTO ARTIFICIAL AUTÔNOMO DE UM GRAFO SENSÓRIO-MOTOR AUTO-ORGANIZÁVEL}

Tese apresentada à Escola Politécnica da Universidade de São Paulo para obtenção do Título de Doutor em Ciências.

Área de Concentração:

Sistemas Eletrônicos

Orientador:

Prof. Dr. Marcio Lobo Netto 
Este exemplar foi revisado e alterado em relação à versão original, sob responsabilidade única do autor e com a anuência de seu orientador.

São Paulo, 4 de abril de 2016.

Assinatura do autor

Assinatura do orientador

FICHA CATALOGRÁFICA

Muñoz, Mauro Enrique de Souza

Desenvolvimento Artificial Autônomo de um Grafo Sensório-Motor Auto-Organizável/ M. Enrique de Souza Muñoz. - ed. rev. - São Paulo, 2016.

$135 \mathrm{p}$.

Tese (Doutorado) - Escola Politécnica da Universidade de São Paulo. Departamento de Engenharia de Sistemas Eletrônicos (PSI).

1. Inteligência Computacional. 2. Inteligência Artificial Construtivista. 3. Inteligência Sensório-Motora. 4. Agentes Cognitivos. 5. Noção de Objeto. 6. Grafo Sensório-Motor. I. Universidade de São Paulo. Escola Politécnica. Departamento de Engenharia de Sistemas Eletrônicos (PSI). II. t. 


\section{AGRADECIMENTOS}

Agradeço ao departamento de engenharia de sistemas eletrônicos da Escola Politécnica (POLI) da Universidade de São Paulo (USP) e ao Conselho Nacional de Desenvolvimento Científico e Tecnológico $(\mathrm{CNPq})$ por tornarem possível cursar este programa de doutorado com bolsa, possibilitando que eu me dedicasse exclusivamente a esta pesquisa. 


\section{RESUMO}

A teoria de Jean Piaget sobre o desenvolvimento da inteligência tem sido utilizada na área de inteligência computacional como inspiração para a proposição de modelos de agentes cognitivos. Embora os modelos propostos implementem aspectos básicos importantes da teoria de Piaget, como a estrutura do esquema cognitivo, não consideram o problema da fundamentação simbólica e, portanto, não se preocupam com os aspectos da teoria que levam à aquisição autônoma da semântica básica para a organização cognitiva do mundo externo, como é o caso da aquisição da noção de objeto.

Neste trabalho apresentamos um modelo computacional de esquema cognitivo inspirado na teoria de Piaget sobre a inteligência sensório-motora que se desenvolve autonomamente construindo mecanismos por meio de princípios computacionais pautados pelo problema da fundamentação simbólica.

O modelo de esquema proposto tem como base a classificação de situações sensório-motoras utilizadas para a percepção, captação e armazenamento das relações causais determiníscas de menor granularidade. Estas causalidades são então expandidas espaço-temporalmente por estruturas mais complexas que se utilizam das anteriores e que também são projetadas de forma a possibilitar que outras estruturas computacionais autônomas mais complexas se utilizem delas.

O modelo proposto é implementado por uma rede neural artificial feed-forward cujos elementos da camada de saída se auto-organizam para gerar um grafo sensóriomotor objetivado. Alguns mecanismos computacionais já existentes na área de inteligência computacional foram modificados para se enquadrarem aos paradigmas de semântica nula e do desenvolvimento mental autônomo, tomados como base para lidar com o problema da fundamentação simbólica.

O grafo sensório-motor auto-organizável que implementa um modelo de esquema inspirado na teoria de Piaget proposto neste trabalho, conjuntamente com os princípios computacionais utilizados para sua concepção caminha na direção da busca pelo desenvolvimento cognitivo artificial autônomo da noção de objeto. 


\begin{abstract}
In artificial intelligence some cognitive agent models based on Jean Piaget's intelligence development theory have been proposed. Although the proposed models implement some fundamental aspects of this theory, like the cognitive schema struture, they do not consider the symbol grounding problem. Therefore, they are not concerned about the theoretical aspects that lead to the autonomous aquisition of the basic semantics needed by the cognitive organization of the agent's external world, as for the object concept aquisition.

A computational cognitive scheme model inspired on Piaget's theory of the sensorimotor intelligence is presented. The scheme is autonomously built by computational mechanisms using principles considering the symbol grounding problem.

The proposed scheme model uses sensory-motor situations to perceive, capture and store the finest grain deterministic causal relations. These causal relations are then expanded in time and space by more complex computational structures using the first ones. Those complex structures itselves are also designed in a way they can be used by more complex structures, expanding even further the causal relations in time and space.

The proposed scheme model is implemented by an artificial neural network using feedforward architecture. The neural network output layer units progressively organized to compose a sensory-motor graph. Some known computational mechanisms from artificial inteligence were modified to fit to the zero semantic and the autonomous mental development paradigms, conceived in this work as the premises to handle the symbol grounding problem.

The scheme model inspired by Piaget's theory implemented by the proposed self organizing sensorimotor graph in conjunction with the computational principles used, goes toward to the artificial autonomous cognitive development of the object concept.
\end{abstract}




\title{
SUMÁRIO
}

\section{Lista de Ilustrações}

\author{
Lista de Tabelas
}

\section{Lista de Abreviaturas e Siglas}

\author{
Lista de Símbolos
}

1 Introdução 16

2 Fundamentação teórica e contextualização 24

2.1 Conceitos fundamentais . . . . . . . . . . . . . . . . 24

2.1.1 Desenvolvimento Cognitivo Artificial Autônomo - DCAA . . 25

2.1.2 Conceito computacional de esquema . . . . . . . . . 26

2.1.3 Teoria de Piaget sobre a construção do real . . . . . . . . . 28

2.1.3.1 Desenvolvimento da noção de objeto . . . . . . . 31

2.1.3.2 Campo espacial, campo temporal e causalidade . . 33

2.2 Outros modelos baseados em esquemas . . . . . . . . . . 33

2.2.1 Modelos baseados no conceito de item . . . . . . . . . . . . 34

2.2.2 Modelos baseados em transformações direta e inversa . . . . . 39

2.3 Sobre os outros modelos baseados em esquemas . . . . . . . . . . 42

2.3.1 Natureza da informação do aparato sensório-motor . . . . . . 42 
2.3.2 Conexão do esquema ao aparato sensório-motor do agente . 43

2.3.3 Representação das relações sensório-motoras . . . . . . . . . 45

2.3.4 Alcance espaço-temporal . . . . . . . . . . . . . . 46

3 Modelo teórico proposto $\quad 48$

3.1 Átomo de causalidade . . . . . . . . . . . . . . . . . . . . . 49

3.1.1 Representação por domínio sensório-motor . . . . . . . . 50

3.1 .2 Funcionalidade . . . . . . . . . . . . . . 52

3.1 .3 Estados ........................ 53

3.2 Esquema cognitivo . . . . . . . . . . . . . . . 54

3.2.1 Estrutura ....................... 55

3.2.2 Processo de desenvolvimento . . . . . . . . . . 56

3.2 .3 Encadeamento . . . . . . . . . . . . . . 56

3.2 .4 Treinamento ..................... 58

3.2 .5 Divisão . . . . . . . . . . . . . . . . 60

3.2 .6 Fusão . . . . . . . . . . . . . . . . . . . 61

3.2.7 Sobre os objetivos . . . . . . . . . . . . . 64

3.2.8 Sobre o modelo de esquema . . . . . . . . . . . 65

3.3 Coordenação entre esquemas . . . . . . . . . . . . . . 66

3.4 Hierarquia de esquemas . . . . . . . . . . . . . . 67

3.5 Esquemas móveis . . . . . . . . . . . . . . . . . . 68

4 Implementação computacional $\quad \mathbf{7 0}$ 
4.1 Adequação do modelo ao DCAA . . . . . . . . . . . . . . . . . 71

4.2 Classificador para sistemas baseados em DCAA . . . . . . . . . . 72

4.2 .1 Motivação .................... 73

4.2.1.1 Cardinalidade do conjunto de amostras . . . . . 75

4.2.1.2 Representabilidade das amostras . . . . . . 76

4.2.1.3 Determinação autônoma dos parâmetros estruturais 77

4.2.2 Algoritmos de poda . . . . . . . . . . . . 78

4.2 .3 Modelo computacional . . . . . . . . . . . . . . . 79

4.2.3.1 Estrutura . . . . . . . . . . . . . 79

4.2.3.2 Dinâmica das iterações . . . . . . . . . . . 80

4.2.3.3 Otimização da estrutura . . . . . . . . . . . 81

4.2.4 Sobre a autonomia dos parâmetros . . . . . . . . . . . 85

4.2.5 Considerações sobre o classificador . . . . . . . . . . . . 87

4.3 Mecanismo de identificação de descontiguidades . . . . . . . . . . 88

$4.3 .1 \quad$ Estrutura . . . . . . . . . . . . . . 88

4.3.2 Entradas do mapa . . . . . . . . . . . . . . . 90

4.3.3 Atualização dos elementos. . . . . . . . . . . . . . . . . 92

4.3.4 Modificação da estrutura . . . . . . . . . . . . . . . . . . 92

4.3.4.1 Adição de elementos. . . . . . . . . . . . . . . . 94

4.3.4.2 Remoção de elementos. . . . . . . . . . . . . . 95

4.3.5 Identificação dos subconjuntos contíguos e convexos . . . . . 96

4.3.6 Sobre os parâmetros do mecanismo . . . . . . . . . . . 97 
4.3.7 Considerações sobre o mecanismo . . . . . . . . . . . . . 98

4.4 Grafo sensório-motor . . . . . . . . . . . . . . . . . . . 99

4.4.1 Estrutura ..................... 100

4.4.2 Treinamento ..................... 103

4.4.2.1 Dinâmicas da estrutura . . . . . . . . . . 103

4.4.2.2 Treinamento do grafo . . . . . . . . . 105

4.4.3 Considerações sobre o grafo sensório-motor . . . . . . . . . 106

4.4.3.1 Divisão . . . . . . . . . . . . . . . . 107

4.4.3.2 Fusão . . . . . . . . . . . . . . . 107

4.4.3.3 Fronteiras .............. 108

5 Experimentos e resultados $\quad 109$

5.1 Classificador para sistemas baseados em DCAA . . . . . . . . . . . 109

5.1.1 Experimento 2D-Sphere . . . . . . . . . . . . . . 110

5.1.2 Experimento 10D-Sphere . . . . . . . . . . . . 114

5.2 Mecanismo de identificação de descontiguidades . . . . . . . . . 115

5.2.1 Experimentos demonstrativos . . . . . . . . . 116

5.2.1.1 Modificação da estrutura do classificador . . . . . . 116

5.2.1.2 Critérios para contiguidade .......... 118

5.2.2 Experimentos com dados empíricos . . . . . . . . . 119

5.2.2.1 Dados sobre câncer de mama . . . . . . . . . . 120

5.2.2.2 Dados sobre blocos em páginas . . . . . . . . . 121 
5.3 Experimento para o grafo sensório-motor . . . . . . . . . . . 121

6 Conclusões e trabalhos futuros $\quad 126$

6.1 Conclusões . . . . . . . . . . . . . . . . . . 126

6.2 Trabalhos futuros . . . . . . . . . . . . . . 131

$\begin{array}{ll}\text { Referências } & 134\end{array}$ 


\section{LISTA DE ILUSTRAÇÕES}

1 Átomo de causalidade . . . . . . . . . . . . . . . 51

2 Algoritmo de desenvolvimento dos esquemas . . . . . . . . . 57

3 Algoritmo do procedimento de treinamento dos átomos . . . . . . 58

4 Algoritmo do procedimento para a reestruturação do grafo . . . . . . 59

5 Processo de divisão dos átomos de causalidade . . . . . . . . . . . 61

6 Reversibilidade sensório-motora . . . . . . . . . . . . . 62

$7 \quad$ Ilustração do processo de fusão . . . . . . . . . . . . . . . . 63

8 Estrutura do classificador . . . . . . . . . . . . . . . . 79

9 Acoplamento do mecanismo de identificação de descontiguidades à RNA 89

10 Estrutura do grafo sensório-motor $\ldots \ldots 101$

11 Fluxo gerador do treinamento do grafo sensório-motor . . . . . . . 107

12 Experimento $2 D$-Sphere com 6 elementos na camada oculta . . . . . . 112

13 Experimento 2D-Sphere com 20 elementos na camada oculta . . . . . 113

14 Experimento 2D-Sphere com 100 elementos na camada oculta . . . . 113

15 Experimento 10D-Sphere com 200 elementos na camada oculta . . . . 115

16 Experimento com mudança abrupta da classe alvo . . . . . . . . . 117

17 Experimento com mudança abrupta da classe alvo complementar . . . 118

18 Experimento de descontiguidade com uma pequena região conexa . 119

19 Experimento de contiguidade com uma pequena região conexa . . . . 120 
20 Ambiento do experimento do GSM . . . . . . . . . . . . . . 122

21 Interface utilizada para o experimento do GSM $\ldots \ldots$. . . . . . . 123

22 Grafo sensório-motor resultante do experimento do GSM. . . . . . . . 124

23 Contextos sensório-motores do Grafo . . . . . . . . . . . . . . . 124 


\section{LISTA DE TABELAS}

1 Estágios do desenvolvimentos espacial, temporal e causal . . . . . . 33

2 Encadeamento dos átomos de causalidade . . . . . . . . . . . 58

3 Resultados do experimento $2 D$-Sphere . . . . . . . . . . . 111

4 Resultados do experimento 10D-Sphere . . . . . . . . . . 115

5 Resultados do experimento com a base de dados BreastCancer utilizando uma RNAFF-1 com 5 elementos na camada oculta. . . . . . . 121

6 Resultados dos experimentos para o conjunto de dados PageBlock. . . 121 


\section{LISTA DE ABREVIATURAS E SIGLAS}

CLA Constructivist Learning Architecture.

CLASM Constructivist Learning Architecture Schema Mechanism.

COPDE Completly Observable Partially Deterministic Environment.

CSN Comprometimento com Semântica Nula.

DCAA Desenvolvimento Cognitivo Artificial Autônomo.

DMA Desenvolvimento Mental Autônomo.

PB Parametric Biases.

PFS Problema da Fundamentação Simbólica.

POPDE Partially Observable Partially Deterministic Environment.

RNN Rede Neural Recorrente.

RNNPB Recurrent Neural Network with Parametric Biases.

SOM Self-Organizing Map.

TDI Transformações Direta e Inversa. 


\section{LISTA DE SÍMBOLOS}

$\bar{S} \quad$ Espaço sensório do agente.

$\bar{A} \quad$ Espaço motor do agente.

$S \quad$ Espaço sensório do esquema.

A Espaço motor do esquema.

$s \quad$ Estado dos sensores do esquema; sensação do esquema; ou sensação.

a Estado dos atuadores do esquema; ação do esquema; ou ações.

$x \quad$ Estado sensório-motor do esquema.

$t \quad$ Instante de tempo.

$s_{t} \quad$ Situação sensória: estado dos sensores do esquema em $t$.

$a_{t} \quad$ Situação motora: estado dos atuadores do esquema em $t$.

$x_{t} \quad$ Situação sensório-motora: estado dos sensores e atuadores do esquema em $t$.

$Q \quad$ Átomo de causalidade: conjunto que representa seu contexto sensório-motor.

$Q_{S} \quad$ Contexto sensório do átomo de causalidade $Q$.

$Q_{A} \quad$ Contexto motor do átomo de causalidade $Q$.

$Q_{O} \quad$ Objetivo sensório do átomo de causalidade $Q$.

$Q_{A}(s)$ Contexto motor do átomo $Q$ associado à sensação $s$.

$\bar{Q} \quad$ Conjunto dos átomos que compõem o grafo do esquema.

$\bar{R} \quad$ Matriz de relações do grafo do esquema.

E Esquema. 
$Q^{i} \quad$ i-ésimo átomo do grafo do esquema.

$E^{*} \quad$ Objetivo do esquema $E$.

$E_{N} \quad$ Número de átomos do grafo do esquema. 


\section{INTRODUÇÃO}

A noção de objeto é fundamental para a compreensão do mundo tal qual o concebemos. Com a forma de pensamento utilizada por nós humanos é praticamente impossível imaginar um mundo sem concebê-lo como sendo composto por entidades invariantes tanto no espaço quanto no tempo. Apesar da noção de objeto ser tão básica e primordial para nossa concepção do mundo, Kant afirma que o objeto em si é inalcançável e que o conceito que formamos acerca de um objeto é fruto da adequação dos fenômenos ${ }^{1}$ à nossa intuição pura (KANT, 1781).

Sob a perspectiva computacional, as informações geradas pelos fenômenos pensados por Kant nos chegam através dos sinais gerados pelos nossos sensores. Em outras palavras, o conceito que temos do objeto externo é construído internamente pela adequação das informações sensoriais a uma forma inata de categorização, ou seja, da intuição pura. Note que há uma distinção semântica entre os sinais sensórios que captamos e as informações sensórias geradas pelos fenômenos que observamos. Enquanto os sinais sensórios são desprovidos de semântica, as informações sensórias estão associadas semanticamente aos fenômenos observados e são chave para a construção dos conceitos que temos acerca dos objetos externos. A noção de objeto pode ser vista como a abstração que nos permite transformar os sinais sensórios que nos chegam em informações sobre entidades externas espaço-temporalmente constantes. De posse da noção de objeto, ao invés de interagirmos diretamente com os sinais sensórios, passamos a interagir com entidades externas que geram estes sinais, ou seja,

\footnotetext{
${ }^{1}$ Nas palavras de Kant: "O objeto indeterminado de uma intuição empírica chama-se fenômeno."
} 
com as informações que interpretamos acerca dos sinais. Por outro lado, a construção da abstração que nos permite extrapolar de interações baseadas nos sinais sensórios para interações baseadas nas informações sobre entidades externas, a noção de objeto, é possivel justamente pela deteção das constâncias espaço-temporais percebidas no domínio dos sinais sensórios e motores.

Piaget, biólogo de formação, dedicou-se ao estudo do desenvolvimento da inteligência nos seres humanos desde o nascimento até o ponto onde o pensamento abstrato se faz possível. Em especial, Piaget aponta o período inicial do desenvolvimento da inteligência como sendo aquele no qual se desenvolve a inteligência sensório-motora, período no qual a criança organiza seu sistema cognitivo para conceber a realidade que a cerca. Segundo Piaget, a construção da realidade pela criança se dá pelo desenvolvimento das noções de objeto e de causalidade, o que ocorre conjuntamente com a organização interna dos campos espacial e temporal (PIAGET, 1936; PIAGET, 1937; PIAGET, 1964). Da mesma forma que para Kant, para Piaget a noção de objeto se dá por uma componente empírica e outra inata ${ }^{2}$, sendo que para Piaget a componente inata tem como base um sistema que se desenvolve autonomamente por um processo intrínsico de adaptação cognitiva no qual os desequilíbrios causados pelas situações advindas do mundo externo são compensados pela reorganização do sistema na direção de sua reequilibração (PIAGET, 1977).

A teoria de Piaget sobre o desenvolvimento da inteligência está baseada no conceito de esquema cognitivo. Os esquemas são estruturas cognitivas presentes desde o nascimento da criança sendo responsáveis pelos reflexos observados nos recém nascidos. Conforme os esquemas se modificam, adaptando-se às situações impostas pelo meio, eles passam a se coordenar, formando uma rede de esquemas hierárquica e coesa que constituirá o sistema cognitivo.

Com os recentes avanços nas áreas de ciências cognitivas e neurociências devidos à

\footnotetext{
${ }^{2}$ Que é inerente desde o nascimento (Dicionário Priberam da Língua Portuguesa).
} 
ajuda de tecnologias relacionadas ao imageamento do cérebro como fMRI, EEG, PET $^{3}$ e outras tecnologias de observação e intervenção, um número maior e mais profundo de detalhes acerca do trabalho interno do cérebro estão sendo revelados. Conjuntamente com os avanços em inteligência computacional, neurocomputação e robótica, estas descobertas estimularam a proposição do conceito de Desenvolvimento Mental Autônomo (DMA) que segundo Weng pode ser definido como o processo no qual um sistema cerebral, natural ou artificial, dentro de um corpo e sob o controle de um programa de desenvolvimento intrínsico específico à sua espécie, desenvolve capacidades mentais baseadas nas interações com o ambiente através de seus sensores e atuadores (WENG; MCCLELLAND; PENTLAND, 2006).

Assim, um sistema que siga o DMA, após concebido e iniciada suas fases de interação com o meio, deve ser o único responsável por seu desenvolvimento cognitivo. Também, a concepção do sistema deve ser realizada sem nenhuma assunção por parte do projetista acerca do meio no qual o agente cognitivo será inserido.

O DMA abre uma nova perspectiva à área de inteligência computacional, aproximando-a da inteligência natural. Isto porque o DMA exclui sistemas inteligentes nos quais o arquiteto do sistema, ou programador, embuta seus próprios conhecimentos na codificação do sistema, limitando a capacidade do sistema em tratar situações inusitadas. Por outro lado, é importante notar que o DMA não exclui sistemas que se desenvolvem com base em ensinamentos externos, como acontece no caso dos aprendizados empíricos ou sociais. Isto porque estas formas de aprendizado se dão pela interação sensório-motora do agente com o meio ambiente (ex: objetos, pessoas ou outros sistemas cognitivos) e não por intervenções diretas do programador no código ou nas representações internas do agente. Ou seja, há uma interação com o sistema e não uma intervenção no sistema. Dito isto, vê-se que os sistemas que seguem a linha do DMA pressupõem a adaptação autônoma do agente a um ambiente inicialmente desco-

\footnotetext{
${ }^{3}$ Functional Magnectic Resonance Imaging (fMRI), Eletroencephalography (EEG) e Positron Emission Tomography (PET).
} 
nhecido aproximando-o das capacidades da inteligência humana e, portanto, estando mais próximo de realizar os feitos da adaptação cognitiva percebida nos humanos.

O paradigma do DMA, além de se mostrar em conformidade com a teoria do desenvolvimento da inteligência proposta por Piaget, segue em direção à solução do Problema da Fundamentação Simbólica (PFS) ${ }^{4}$. Porém, ainda não trata específicamente da problemática das atribuições semânticas ao agente cognitivo. O problema da fundamentação simbólica pode ser expresso pela reflexão sobre a seguinte pergunta:

Como a interpretação semântica de um símbolo formal pode se fazer intrínsica ao sistema, ao invés de apenas parasitar os significados que estão em nossas cabeças ${ }^{5}$ ? Como podem os significados dos tokens simbólicos sem significação, manipulados somente com base em suas representações arbitrárias, fundamentarem-se em algo além de outros símbolos sem significação? (HARNAD, 2003).

Conforme Taddeo, a fundamentação simbólica é o problema de como um agente artificial pode "autonomamente elaborar sua própria semântica" utilizando-se exclusivamente da interação com o ambiente no qual está inserido (TADDEO; FLORIDI, 2005).

O PFS não é um desafio apenas para agentes que têm como foco o processamento simbólico, mas também para outros sistemas que possam utilizar a metáfora de agentes, tais como os da área de robótica, por exemplo. Williams argumenta que para os agentes robóticos responderem de forma apropriada a situações inusitadas, ou seja, situações para as quais eles não foram explicitamente programados é preciso que o sistema possua capacidades sofisticadas de fundamentação. Novas situações precisam ser interpretadas de forma significativa pelo agente com base em suas próprias semânticas e não apenas com base nas semânticas do projetista (WILLIAMS et al., 2009).

Buscando solucionar o PFS, Taddeo estabelece a condição de Comprometimento

\footnotetext{
${ }^{4}$ Do inglês: The Symbol Grounding Problem.

${ }^{5}$ Cabeças dos projetistas dos sistemas.
} 
com Semântica Nula $(\mathrm{CSN})^{6}$ que deve ser satisfeita por sistemas que se disponham a solucionar o PFS. Esta condição diz que: (a) nenhuma forma de inatismo é permitida: nenhum recurso semântico deve ser pressuposto como pré-instalado no agente; e (b) também, nenhuma forma de externalismo é permitida: nenhum recurso semântico que venha do meio externo por um deux ex machina proficiente semanticamente deve ser carregado para o agente (TADDEO; FLORIDI, 2005).

Neste trabalho, adotaremos o termo Desenvolvimento Cognitivo Artificial Autônomo (DCAA) ao invés de Desenvolvimento Mental Autônomo (DMA) para evidenciar não só o foco na construção de sistemas cognitivos artificiais capazes de se desenvolverem autonomamente, contrapondo a construção de sistemas que visem imitar ou estudar sistemas cognitivos naturais, como também para incorporar ao conceito as premissas estabelecidas pelo Comprometimento com Semântica Nula (CSN).

A teoria de Piaget parece conformar-se tanto com o paradigma do DMA quanto com as diretrizes modernas apontadas pelo CSN para a solução do problema da fundamentação simbólica, pois o sistema proposto por Piaget desenvolve-se de forma autônoma sem depender de semântica externa engendrada em sua estrutura, o que torna sua teoria atraente para ser tida como direcionadora de modelos que sigam o paradigma do DCAA.

Alguns trabalhos na área de computação que seguem o conceito de esquema já foram propostos, destacando-se o modelo apresentado por Drescher que se utiliza fortemente da teoria piagetiana para propor um modelo de agente auto-organizável utilizando uma abordagem probabilística (DRESCHER, 1991), e também o modelo proposto por Gläser et. al. que utiliza uma abordagem conexionista para a implementação do sistema (GLäSER; JOUBLIN; GOERICK, 2009). Estes e outros modelos serão vistos com maiores detalhes na Seção 2.2. Por hora, vamos apenas adiantar que os modelos estudados constroem autonomamente estruturas capazes de organizar os sinais sensório-

\footnotetext{
${ }^{6}$ Do inglês: Zero Semantic Commitment Condition.
} 
motores do agente de forma a que este possa realizar as tarefas a que se propõe. Porém, como será visto, estes modelos não seguem completamente a premissa do CSN e, o mais importante, restringem-se à organização dos sinais sensórios, não construindo a semântica necessária à organização das informações geradas pelos fenomenos observados, ou seja, não desenvolvem estruturas cognitivas capazes de organizar os sinais percebidos por seus sensores e atuadores para que seja possível perceber informações acerca das entidades espaço-temporalmente constantes responsáveis pela geração dos sinais percebidos. O mecanismo cognitivo que possibilita organizar os sinais percebidos de modo a permitir que estas organizações sejam extrapoladas para informações que possibilitem conceber os geradores destes sinais como objetos é ao que nos referimos como sendo a noção de objeto.

O presente trabalho tem como foco a proposição de um grafo sensório-motor que represente um esquema cognitivo e que permita seguir o estudo do desenvolvimento autônomo da noção de objeto por um sistema cognitivo artificial construído com inspiração na teoria do desenvolvimento da inteligência de Jean Piaget e que se adeque ao paradigma do DCAA. O sistema proposto inicia sem conhecimento ou semântica acerca do meio no qual será inserido e com o qual interagirá. Após iniciado, o sistema passa a organizar os sinais sensório-motores, estruturando suas relações em direção à constituição de grafos sensório-motores, versões computacionais dos esquemas cognitivos piagetianos.

No Capítulo 2 é feita uma breve introdução do conceito computacional de esquema na teoria de Piaget. Também são mostrados os estudos realizados sobre alguns modelos de sistemas que seguem a teoria de esquemas e que foram tomados como base comparativa para este trabalho.

O Capítulo 3 apresenta o modelo teórico proposto e os modelos dos conceitos por ele utilizados. Desde o modelo do átomo de causalidade, responsável por organizar as relações espaço-temporais determinísticas de menor granularidade capazes de serem 
apreendidas pelo sistema, até o modelo do grafo sensório-motor que é responsável pela expansão, tanto no espaço quanto no tempo destas relações determinísticas e que desempenha, no modelo, o papel do esquema piagetiano.

O Capítulo 4 expõe as escolhas referentes à implementação computacional do modelo proposto. Apesar do modelo teórico apresentado estar em conformidade com o paradigma do DCAA, repensar o modelo sob o ponto de vista computacional introduz novas questões e desafios no tocante à adequação de técnicas ou vertentes computacionais já existentes para também se adequarem ao paradigma do DCAA. Assim, neste capítulo são expostas algumas soluções investigadas e que nos permitiram implementar computacionalmente o modelo teórico mantendo a coerência com o paradigma do DCAA.

O Capítulo 5 é dedicado à exposição dos experimentos realizados na averiguação da validade das escolhas referentes à implementação computacional proposta. Este capítulo é dividido em três partes. A primeira trata dos experimentos utilizados para o teste de um novo algoritmo proposto para encontrar de forma autônoma o número de elementos da camada oculta de redes neurais artificiais feed-forward. Na segunda são apresentados os experimentos utilizados para validar um mecanismo autônomo de identificação de subconjuntos de classes encontradas por classificadores que se utilizam de redes neurais artificiais. Finalmente, na terceira parte são mostrados os experimentos para a validação da implementação do grafo sensório-motor que representa o modelo teórico do esquema cognitivo proposto. Este último, apesar de extremamente simples, é de fundamental importância tanto para a averiguação da conformidade da implementação com o modelo teórico quanto do próprio teste do código utilizado.

Finalmente, no Capítulo 6.1 são apresentadas algumas conclusões sobre a pesquisa realizada e apontamentos para trabalhos futuros. É importante notar que esta tese sobre a utilização do paradigma computacional do DCAA para a concepção de sistemas com base na teoria de Piaget (sistemas construtivistas) tem como direção o alcance do 
desenvolvimento autônomo da noção de objeto, mas que se restringe à proposição de um modelo computacional de esquema cognitivo que possa ser utilizado por pesquisas futuras que sigam em tal direção. Ou seja, esta tese propõe subsídios em conformidade com o DCAA que podem ser utilizados como suporte por iniciativas que caminhem na direção do desenvolvimento autônomo da noção de objeto. 


\section{FUNDAMENTAÇÃO TEÓRICA E CONTEXTUALIZAÇÃO}

Este capítulo mostra os fundamentos teóricos assim como o contexto científico computacional que serviram de motivação e amparo para o desenvolvimento do trabalho apresentado. Inicialmente serão expostos os conceitos teóricos que fundamentaram o desenvolvimento da presente tese. Em seguida, com o intuito de contextualizar a pesquisa com seus pares serão descritos os principais modelos computacionais estudados e que têm como ponto comum a fundamentação no conceito de esquema. Por último serão realçados alguns aspectos por nós considerados importantes acerca dos modelos estudados quanto às suas adequações aos conceitos fundamentais expostos.

\subsection{Conceitos fundamentais}

A base conceitual primordial deste trabalho vem das teorias epistemológicas iniciadas e desenvolvidas por Jean Piaget acerca do desenvolvimento da inteligência sensório-motora na criança, período no qual se dá o que Piaget chama de construção do real e também o desenvolvimento da noção de objeto (PIAGET, 1937). Tais teorias foram utilizadas para a geração de modelos computacionais buscando ampliar o conhecimento e a utilização dos conceitos de inteligência construído por estas teorias. Com a introdução de novos paradigmas na área de inteligência computacional como o DMA e o CSN, os modelos computacionais sobre as teorias epistemológicas, mesmo ainda não sedimentados, merecem nova atenção. 
Nesta seção passaremos pelos conceitos epistemológicos sobre a inteligência sensório-motora, sobre o núcleo dos modelos computacionais até então adotados e sobre os novos paradigmas sendo adotados na concepção de sistemas inteligentes. Porém, por questões didáticas, a exposição destes conceitos fundamentais para este trabalho serão apresentados em ordem cronológica inversa.

Inicialmente será apresentado o paradigma computacional que versa sobre as condições e premissas que sistemas computacionais visando inteligência artificial possam ter seu desenvolvimento considerado autônomo. Alicerçados por estas concepções, apresentaremos o núcleo dos modelos computacionais atuais inspirados nas teorias construtivistas. Por último será apresentado um resumo da teoria de Piaget acerca do desenvolvimento da inteligência sensório-motora para que este possa ser absorvido sob as expectativas geradas pela leitura dos conceitos anteriores.

\subsubsection{Desenvolvimento Cognitivo Artificial Autônomo - DCAA}

Durante este trabalho nos utilizamos do conceito, por nós cunhado, de Desenvolvimento Cognitivo Artificial Autônomo (DCAA) para ressaltar o comprometimento do sistema proposto tanto com o paradigma do Desenvolvimento Mental Autônomo (DMA) (WENG; MCCLELLAND; PENTLAND, 2006) quanto com o Comprometimento com Semântica Nula (CSN) (TADDEO; FLORIDI, 2005). Assim, com o DCAA, queremos ressaltar nosso compromisso de autonomicidade tanto com o desenvolvimento das estruturas do sistema, quanto com a responsabilidade sobre a forma com que as semânticas cognitivas por ele utilizadas são geradas.

As consequências da adoção do DCAA se fazem presente nas concepções tanto do sistema computacional em si quanto do entorno no qual o sistema se desenvolverá.

Pensar que a autonomia do desenvolvimento cognitivo de um sistema artificial está principalmente na não contaminação da sua dinâmica pelos conceitos cognitivos do projetista sobre os possíveis ambientes a serem experienciados pelo agente levanta 
a questão sobre quais são as possíveis formas de contaminação que podem ocorrer quando da concepção do sistema.

Basicamente a contaminação do pensar do projetista se dá na concepção do comportamento ou da finalidade (ou objetivação) do sistema. Programas computacionais concebidos para serem utilizados como ferramentas seguem comportamentos, ou fluxos, pensados e escritos ou regrados segundo a vontade do projetista, assim como suas finalidades também se ajustam às necessidades externas já estabelecidas. Já ferramentas computacionais na área de inteligência computacional tais como classificadores e sistemas baseados em algoritmos genéticos têm seus comportamentos relaxados, mas não muito suas finalidades. Os conceitos do projetistas não estão sendo impostos no como, mas continuam sendo impostos no o que, ou seja, na finalidade. Também, quando o que se busca não está definido, como nos casos de treinamentos supervisionados ou por reforço, apesar do projetista não explicitar os objetivos e os conceitos sobre estes estão sendo transmitidos pela escolha do entorno que está sendo utilizado para a estabilização do funcionamento do sistema.

A não imposição ou contaminação dos conceitos do projetista tanto no comportamento quanto na finalidade do sistema parecem torná-lo inviável ou sem propósito. Porém, nos interessam os sistemas capazes de encontrar suas próprias formas de comportamento (fluxos) e que tenham como consequência resultados que possamos aproveitar, mas que não se restrinjam aos nossos conceitos.

\subsubsection{Conceito computacional de esquema}

Nos sistemas construtivistas, os esquemas são as unidades cognitivas básicas que compõem o sistema cognitivo de um agente computacional. Cada modelo de esquema estudado possui uma abordagem computacional distinta das demais, porém os conceitos utilizados para a concepção dos esquemas seguem próximos à linha do modelo proposto por Drescher (DRESCHER, 1991). Desta forma, apresentaremos a concepção 
utilizada por Drescher para introduzir a ideia por trás dos modelos estudados (Seção 2.2). Na Seção 3.1 introduziremos o modelo de esquema proposto neste trabalho.

O esquema é uma entidade computacional que age exclusivamente com base nos sinais provenientes dos seus sensores e atuadores. Tanto os sensores quanto os atuadores utilizados pelo esquema para interagir podem ser de natureza externa, quando conectam-se ao meio externo do sistema cognitivo (por exemplo, ao próprio corpo do agente) ou de natureza interna, quando conectam-se a outras estruturas cognitivas, como por exemplo, a outros esquemas ou a redes de esquemas.

$\mathrm{O}$ agente possui sensores e atuadores para interagir com o ambiente. Representaremos por $\bar{S}$ o conjunto de todos os possíveis estados dos sensores do agente e por $\bar{A}$ o conjunto de todos os possíveis estados de seus atuadores. Assim como o agente, o esquema possui sensores e atuadores que são conectados ao aparato sensório-motor do agente (interno ou externo). Representaremos por $S \subseteq \bar{S}$ o conjunto de todos os estados dos sensores do esquema e por $A \subseteq \bar{A}$ o conjunto de todos os estados de seus atuadores. Denominaremos de sensação do esquema, ou apenas sensação, o estado dos sensores do esquema. Da mesma forma, denominaremos de ação do esquema, ou apenas ação, o estado dos atuadores do esquema. A sensação do esquema no instante $t \in \mathbb{N}$ será representada por $s_{t} \in S$ e sua ação, por $a_{t} \in A$.

O esquema, conforme Drescher, pode ser representado pela trinca $[C, a, R]$ ou pela notação:

$$
C \stackrel{a}{\rightarrow} R
$$

onde: $C \subseteq S$ representa o contexto do esquema, $a \in A$ representa a ação a ser executada e $R \subseteq S$ representa o resultado do estado sensório resultante da aplicação da ação $a$. Em outras palavras, o esquema indica que quando os sensores estiverem em algum estado que pertença ao seu contexto $\left(s_{t} \in C\right)$, então, se o estado $a_{t}=a$ for aplicado aos seus atuadores, os sensores assumirão algum estado que pertence ao seu resultado $\left(s_{t+k} \in R\right.$ para algum $\left.k \in \mathbb{N}^{*}\right)$. 
Um ponto importante a ser ressaltado quanto ao modelo proposto por Drescher é que os sensores e os atuadores são binários e quando conectados ao aparato sensóriomotor do agente representam, respectivamente, a presença de algum item do mundo externo, ou a aplicação de alguma ação pelo corpo do agente ao mundo.

Além dos estados dos sensores e atuadores, o esquema possui dois estados intrínsicos que dizem se ele pode ser utilizado e se ele realmente está sendo utilizado. Desta forma, diz-se que um esquema está excitado quando seus sensores estão em algum estado $s \in C$ e diz-se que ele está ativado se sua ação $a$ é realmente passada aos seus atuadores.

Vê-se também que, quando $k=1$ o resultado obtido é concebido para o menor intervalo de tempo de resposta do sistema. Nesta situação o esquema pode ser visto como o átomo de causalidade do sistema. Ou seja, o esquema armazena a informação do resultado a ser obtido logo após a aplicação de uma dada ação a uma certa situação com a maior resolução temporal possível.

A ampliação do alcance temporal do resultado previsto pelo esquema se dá pela organização dos esquemas em um sistema de rede hierárquica onde os esquemas nos níveis superiores percebem (sensores) se os esquemas dos níveis inferiores estão excitados ou não, e também os comandam (atuadores) ativando-os ou não. Assim, um esquema de nível superior pode, por exemplo, iniciar a execução de uma tarefa complexa e de longa duração, comandando as ativações dos esquemas dos níveis inferiores.

\subsubsection{Teoria de Piaget sobre a construção do real}

$\mathrm{Na}$ criança, os esquemas sensório-motores são estruturas hereditárias que manifestam-se inicialmente como reflexos. Os reflexos, então, sofrem suas primeiras modificações adaptativas conforme a criança os exercita e passam, em seguida, a suportar as primeiras reações adquiridas utilizando-se do que Piaget chama de reações circulares primárias. A preensão é um exemplo das primeiras reações adquiridas. 
Os esquemas primários estão intimamente ligados aos membros e órgãos da criança e permitem a ela estabelecer cada vez mais o controle sobre estes. Conforme há o amadurecimento dos esquemas primários, começa também a haver o treinamento de esquemas secundários, responsáveis por controlar e coordenar diferentes esquemas primários. Da mesma forma, Piaget vislumbra uma terceira ordem hierárquica de esquema, que coordenam os esquemas secundários e desempenham tarefas intelectualmente mais complexas.

Após o exercício dos reflexos, os esquemas começam a apresentar adaptações sensório-motoras intencionais, passando por fases como:

- os processos destinados a fazer durar os espetáculos interessantes;

- a coordenação dos esquemas secundários;

- a aplicação de esquemas conhecidos a novas situações;

- a organização de esquemas móveis;

- o reconhecimento de índices e sua utilização na previsão;

- a exploração dos objetos e dos fenômenos novos;

- a descoberta de novos meios pela exercitação dos meios já descobertos;

- a descoberta de novos meios por experimentação ativa;

- a invenção de novos meios por combinação mental.

Vê-se que para Piaget, os esquemas partem dos reflexos inatos até a construção de uma rede hierárquica de esquemas capazes de mentalmente inventar novos meios.

Para Piaget a atividade intelectual do indivíduo começa ainda na confusão entre a experiência e a consciência de si. Porém, há um aumento progressivo do relacionamento entre as zonas cada vez mais profundas e afastadas do real e as operações 
cada vez mais íntimas da atividade própria. A inteligência não começa nem pelo conhecimento do eu nem pelo das coisas enquanto tais, mas pelo conhecimento de sua interação, e é ao orientar-se simultaneamente para os dois pólos dessa interação que ela organiza o mundo, organizando-se a si mesma (PIAGET, 1937, pg 361).

Segundo Piaget, qualquer conhecimento é, ao mesmo tempo, acomodação do sujeito ao objeto e assimilação do objeto ao sujeito e, portanto, o progresso da inteligência se opera no duplo sentido da exteriorização e da interiorização e tem como pólos o apossar-se da experiência física e a conscientização do próprio funcionamento intelectual. Desta forma, o conhecimento e construção mental do mundo físico (real) está intimamente relacionado ao progresso reflexivo do raciocínio sobre si mesmo. Enfim, esse processo de relacionamento entre um universo cada vez mais exterior ao eu e uma atividade intelectual que progride em interioridade é que explica a evolução das categorias do real, isto é, das noções de objeto, de espaço, de causalidade e de tempo (PIAGET, 1937, pg 363).

É importante notar que as categorias do real são desenvolvidas concomitantemente, e que este desenvolvimento se dá durante a fase do desenvolvimento da inteligência sensório-motora. Note também que estas categorias podem ser vistas como aspectos distintos da evolução de uma mesma estrutura cognitiva e, por isso mesmo, desenvolvem-se concomitantemente. Assim como no estudo da inteligência sensóriomotora, Piaget divide seus o desenvolvimentos destas categorias em seis estágios. (PIAGET, 1936; PIAGET, 1937; PIAGET, 1964).

A seguir cada uma destas categorias, juntamente com seus estágios de desenvolvimento, serão descritas de forma suscinta para que se tenha uma idéia melhor da natureza e da importância de cada uma delas na construção do real pela criança. 


\subsubsection{Desenvolvimento da noção de objeto}

A criança, quando nasce, não concebe ou percebe o mundo como nós, em forma de objetos substanciais, permanentes e de dimensões constantes. Isto porque a noção de objeto, longe de ser inata ou dada pronta na experiência, constrói-se pouco a pouco. Esta construção ocorre conforme os seguintes estágios:

- Estágios I e II: nenhuma conduta especial relativa aos objetos desaparecidos;

- Estágio III: início de permanência, prolongando os movimentos de acomodação;

- Estágio IV: procura ativa do objeto desaparecido, porém sem considerar a sucessão dos deslocamentos visíveis;

- Estágio V: a criança considera os deslocamentos sucessivos do objeto;

- Estágio VI: representação dos deslocamentos invisíveis;

Estes estágios foram definidos de forma a refletir as condutas observáveis durante o processo de constituição da noção de objeto. Porém, subjacentes a eles, Piaget destaca três métodos utilizados pela criança para constituir um mundo objetivo:

1. Previsão fenomenológica: o objeto é, no início, apenas o prolongamento dos movimentos de acomodação, ou seja, o fenômeno gerado pelo objeto pode ser previsto pelos esquemas;

2. Coerência experimental: depois, o objeto é o ponto de interseção, ou de assimilação recíproca, dos esquemas múltiplos que manifestam as diferentes modalidades da ação própria, ou seja, o fenômeno deve apresentar coerência em experiências distintas (coordenação dos esquemas);

3. Inserção em sistema dedutivo: enfim, o objeto se completa em correlação com a causalidade na medida em que essa coordenação dos esquemas leva à cons- 
tituição de um universo espaço-temporal inteligível e dotado de permanência (compreensão relativa a um sistema dedutivo de conjunto).

Expostas as condutas e os processos envolvidos na construção da noção de objeto, cabe agora analisar o que ocorre internamente com os esquemas cognitivos.

A sucessão dos estágios distinguidos prova que a construção da noção de objeto se deve muito mais a uma compreensão progressiva do que a aquisições fortuitas. Se há experiências, elas são dirigidas: ao descobrir o objeto, a criança organiza seus esquemas motores e elabora relações operatórias em vez de sofrer de modo passivo à pressão dos fatos. Nas palavras de Piaget:

A permanência do objeto se deve à dedução construtiva que a assimilação recíproca dos esquemas secundários constitui a partir do quarto estágio, isto é, a coordenação dos esquemas que se tornaram móveis. Até esse nível, o objeto simplesmente prolonga a atividade própria: sua permanência é apenas prática e não substancial, porque o universo não se destaca da ação e não se objetiva em um sistema de relações. A coordenação dos esquemas primários, em particular a coordenação entre a visão e a preensão, que faz surgir as reações circulares secundárias, tem exatamente como resultado uma exteriorização relativa das coisas, mas enquanto os esquemas secundários permanecerem globais ou indiferenciados em vez de se dissociarem para melhor se unir, esta exteriorização não chegará a constituir uma permanência substancial. Ao contrário, a partir do quarto estágio, os esquemas secundários tornam-se móveis graças a uma assimilação recíproca que lhes permite combinarem-se entre si de todos os modos: é esse processo de dissociação e reagrupamento complementares que, engendrando os primeiros atos de inteligência propriamente dita, permite à criança construir um mundo espaço-temporal 
de objetos dotados de causalidade própria (PIAGET, 1937, pg 107).

Vê-se que a construção da noção de objeto, além dos processos de assimilação e acomodação dos esquemas primários e secundários, e suas coordenações, tem como requisito também a diferenciação e mobilidade de recombinação dos esquemas secundários.

\subsubsection{Campo espacial, campo temporal e causalidade}

O desenvolvimento do campo espacial, da causalidade e do campo temporal se dão simultaneamente ao da noção de objeto. Como dito anteriormente estes são aspectos do desenvolvimento das estruturas internas e, portanto, não serão descritos com mais detalhes. Porém, para se ter uma idéia do desenvolvimento da criança com relação a estes aspectos, eles são resumidos na Tabela 1.

\begin{tabular}{|c|c|c|c|}
\hline Estágios & Campo espacial & Causalidade & Campo temporal \\
\hline I e II & $\begin{array}{l}\text { Grupos práticos e heterogê- } \\
\text { neos. }\end{array}$ & $\begin{array}{l}\text { Contato entre a atividade interna e } \\
\text { o meio exterior; causalidade pró- } \\
\text { pria dos esquemas primários. }\end{array}$ & $\begin{array}{l}\text { Tempo próprio e as sé- } \\
\text { ries práticas. }\end{array}$ \\
\hline III & $\begin{array}{l}\text { Coordenação dos grupos } \\
\text { práticos; constituição dos } \\
\text { grupos subjetivos. }\end{array}$ & Causalidade mágico-fenomenista. & Séries subjetivas. \\
\hline IV & $\begin{array}{l}\text { Passagem dos grupos subje- } \\
\text { tivos aos grupos objetivos; } \\
\text { descoberta das operações re- } \\
\text { versíveis. }\end{array}$ & $\begin{array}{l}\text { Exteriorização e a objetivação ele- } \\
\text { mentares da causalidade. }\end{array}$ & $\begin{array}{l}\text { Início da objetivação } \\
\text { do tempo. }\end{array}$ \\
\hline V & Grupos objetivos. & $\begin{array}{l}\text { Objetivação e a espacialização re- } \\
\text { ais da causalidade. }\end{array}$ & Séries objetivas. \\
\hline VI & Grupos representativos. & $\begin{array}{l}\text { Causalidade representativa; Resí- } \\
\text { duos da causalidade dos tipos pre- } \\
\text { cedentes. }\end{array}$ & Séries representativas. \\
\hline
\end{tabular}

Tabela 1: Características em cada estágio do desenvolvimento da inteligência sensório-motora para a organização do campo espacial, o desenvolvimento da causalidade e a estruturação do campo espacial.

\subsection{Outros modelos baseados em esquemas}

Alguns trabalhos na área de inteligência computacional propondo sistemas inteligentes baseados ou inspirados na teoria de esquemas cognitivos já foram realizados. 
Dentre eles podemos destacar duas vertentes: a de sistemas que se baseiam no trabalho de Drescher e que se utilizam do conceito de item como unidade sensória e motora; e a de sistemas que implementam o esquema com base em transformações diretas para prever o estado sensório futuro e transformações inversas para descobrir qual ação deve ser tomada para atingir um dado estado sensor. Enquanto a primeira vertente é mais utilizada para o estudo do desenvolvimento cognitivo artificial em si, a segunda vertente apresenta um caráter mais prático, sendo mais utilizada em aplicações na área de robótica.

Nesta seção descrevemos alguns trabalhos destas duas vertentes que foram tomados como base comparativa para o modelo proposto.

\subsubsection{Modelos baseados no conceito de item}

Dentre os esquemas estudados podemos destacar o Mecanismo de Esquemas proposto por Drescher, pois trata-se um dos primeiros trabalhos a utilizar fortemente a teoria de Piaget na construção de agentes cognitivos (DRESCHER, 1991). Como ressaltado por Chaput et. al. em 2003, o mecanismo de esquemas proposto por Drescher mantém-se como uma das melhores e uma das poucas implementações acerca da aprendizagem construtivista $^{1}$ (CHAPUT; KUIPERS; MIIKKULAINEN, 2003).

No modelo de Drescher os esquemas são iniciados com um conjunto de itens sensórios primitivos, por exemplo: InFrontOfDoor ou DoorOpened. Da mesma forma há um conjunto de ações primitivas que permitem ao agente manipular o ambiente, por exemplo: OpenDoor ou CloseDoor. Inicialmente o sistema explora o ambiente executando ações aleatórias enquanto monitora os estados dos itens. Assim como explicado na Seção 2.1.2, o esquema representa a previsão de que, dado o estado de um conjunto de itens (contexto), se uma dada ação for realizada, é esperado que os itens assumam um certo estado (resultado). Desta forma, o esquema é dado pela trinca con-

\footnotetext{
${ }^{1}$ Chaput refere-se à teoria de Piaget, também conhecida como construtivismo.
} 
texto/ação/resultado, onde o contexto e o resultado são conjuntos de itens que podem assumir os valores ligado ou desligado, e a ação é a própria ação a ser desempenhada pelo agente. Tomemos como exemplo o seguinte esquema:

$$
\text { +InFront0fDoor/OpenDoor/+DoorOpened }
$$

Este esquema indica que se o agente estiver em frente à porta (+InFrontOfDoor), após executar a ação de abrir a porta (OpenDoor) espera-se que a porta seja aberta $(+$ DoorOpened $)$.

Os esquemas são criados por uma técnica chamada atribuição marginal. Quando o sistema é iniciado gera-se um esquema com contexto e resultado vazios para cada ação primitiva do agente. O sistema mantém informações sobre as correlações entre todos os itens e todos os esquemas. Quando a transição de um item ocorre com grande frequência, um novo esquema é criado com o item como resultado.

Há situações nas quais o estado do ambiente, do qual algum resultado depende, não pode ser percebido diretamente pelo aparato sensório do agente. Por exemplo, no caso da porta, o fato da porta estar ou não trancada é imperativo para o funcionamento do esquema, porém o agente não é capaz de perceber a diferença entre estes dois estados. Este tipo de situação faz com que o esquema não seja confiável, pois nem sempre ele funcionará. Para lidar com este tipo de situação, cria-se um item sintético. Por exemplo:

$$
\text { DoorOpenable }=[+ \text { InFront0fDoor/OpenDoor } /+ \text { DoorOpened }]
$$

Este item sintético, aqui chamado de DoorOpenable, quando ligado indica que o ambiente está em um estado no qual a porta pode ser aberta, ou seja, que a porta está destrancada.

Finalmente, os esquemas também permitem o uso de ações compostas. Quando 
um esquema é criado contendo um resultado único, uma nova ação composta é gerada contendo o resultado do esquema como seu objetivo. Então os esquemas são encadeados de trás para frente. Primeiramente são encontrados todos os esquemas cujos resultados são coerentes com o objetivo, depois são encontrados todos os esquemas cujos resultados são coerentes com os contextos dos primeiros e assim por diante. Como consequência, as ações compostas possuem vários contextos que iniciam uma ou mais cadeias de ações intercaladas por resultados sensórios que levam à obtenção de seu objetivo.

Resumidamente, o mecanismo de esquemas é iniciado com um conjunto de itens e ações primitivas. Utilizando-se da interação com o ambiente cria-se um conjunto de esquemas que são usados para gerar itens sintéticos, quando necessário. Os esquemas, quando possível, são encadeados gerando ações compostas. Este processo continua até que não seja mais necessária a criação de novos itens e esquemas.

Para testar seu agente, Drescher criou um micro-mundo com espaço plano e discreto $^{2}$ com dimensões $7 \times 7$ no qual o agente pode interagir com 2 objetos: uma bola macia e um cubo rígido. $\mathrm{O}$ agente possui um campo de visão com dimensões $5 \times 5$ que pode ser movimentado nas 4 direções cardeais pelo agente e que possui um foco na região central. Quando um objeto está no foco da visão, o agente é capaz de perceber maiores detalhes sobre suas características. O agente também possui uma mão que o permite sentir os objetos que estão à sua volta ou abaixo. A mão pode ser percebida pelo campo visual e também pode ser fechada ou aberta pelo agente. Quando a mão fecha estando sobre um objeto, ela o agarra e o objeto passa a mover-se com a mão, porém apenas um objeto pode ser agarrado por vez. Quando a mão leva um objeto para a sua frente, o agente é capaz de perceber seu gosto.

Outros modelos com base no mecanismo de esquemas de Drescher foram propostos modificando certas particularidades, mas mantendo a essência do modelo original.

\footnotetext{
${ }^{2}$ Implementado por uma matriz bidimensional.
} 
A seguir alguns destes modelos estudados serão visitados ressaltando suas particularidades em relação ao modelo original de Drescher.

Um dos problemas com o modelo de Drescher é o grande esforço computacional por ele exigido, restringindo sua aplicação a cenários simples como o micro-mundo utilizado para testar seu agente. Chaput reimplementa o modelo de Drescher utilizando mapas auto-organizáveis (SOMs) ${ }^{3}$ (CHAPUT; KUIPERS; MIIKKULAINEN, 2003). O sistema é baseado na arquitetura de aprendizagem construtivista $(\mathrm{CLA})^{4}$. Esta arquitetura utiliza uma hierarquia de SOMs. No primeiro nível da hierarquia, os mapas (SOMs) estão conectados às entradas do sistema. Assim, os elementos dos mapas deste nível organizam-se com foco nos eventos mais frequentes observados no espaço sensório do sistema. Os elementos dos mapas do primeiro nível são utilizados como entrada para os mapas do segundo nível e assim por diante construindo a hierarquia do sistema.

Chaput adapta a arquitetura CLA para propor o modelo de mecanismo de esquemas com arquitetura de aprendizagem construtivista (CLASM) $)^{5}$. Os mapas utilizados no CLA possuem sua semântica modificada para que seus elementos representem o contexto e o resultado conforme o esquema de Drescher. A cada mapa do primeiro nível é associada uma ação primitiva. Após treinados, os mapas são examinados para a averiguação de quais elementos do mapa podem compor os esquemas ou não. A trinca [contexto,ação,resultado] utilizada para representar os esquemas é mapeada seguindo a importância que cada item tem na ativação tanto dos elementos que representam o contexto, quanto dos elementos que representam o resultado. Como cada mapa está associado a apenas uma ação, mesmo que composta, a trinca pode ser formada. Da mesma forma que ocorre com os mapas do primeiro nível, os mapas dos níveis superiores são gerados associando-os a ações primitivas ou compostas conforme a estrutura de esquemas já formada.

\footnotetext{
${ }^{3}$ Do inglês: Self-Organizing Maps.

${ }^{4}$ Do inglês: Constructivist Learning Architecture.

${ }^{5}$ Do inglês: Constructivist Learning Architecture Schema Mechanism.
} 
Chaput utiliza o mesmo micro-mundo utilizado por Drescher para testar seu modelo ressaltando a equivalência entre ambos, porém com a vantagem da redução do custo computacional imposto pelo modelo original de Drescher.

Holmes estende o esquema de Drescher para a utilização de variáveis discretas para os sensores e atuadores do agente. Também, a forma de geração e manutenção dos itens sintéticos são modificadas. Enquanto Drescher "se atém à duração média dos estados dos itens sintéticos para prevê-los", Holmes utiliza a predição retroativa do item sintético para gerar esquemas que contenham os itens em seus resultados, tendo como consequência a predição futura de seus estados. Holmes testa seu mecanismo de esquemas em ambientes POMDPs ${ }^{6}$ (HOLMES; ISBELL, 2005).

Assim como Holmes, Perotto propõe um modelo de esquemas muito semelhante ao de Drescher, porém utiliza um ambiente completamente observável, onde o agente percebe a totalidade do ambiente; e parcialmente determinístico, onde alguns elementos do ambiente não são determinísticos $\left(\mathrm{COPDE}^{7}\right)$ para testar seu agente (PEROTTO; BUISSON; ALVARES, 2007). Em seguida, seu modelo é estendido adicionando-se itens sintéticos para permitir o uso do agente em ambientes parcialmente observáveis e parcialmente determinísticos $\left(\mathrm{POPDE}^{8}\right)$.

Yavuz apresenta um agente cognitivo construtivista baseado em esquemas que também utilizam das probabilidades de ocorrência para a geração e refinamento dos esquemas, porém abre a possibilidade para esquemas objetivados. Ou seja, os esquemas possuem um objetivo dado previamente à sua criação. (YAVUZ; DAVENPORT, 1997).

Wazlawick propõe um modelo de esquemas cognitivos operatórios, não se atendo à fase sensório-motora do desenvolvimento e, portanto, o agente cognitivo por ele proposto não possue entradas sensório-motoras, mas simbólicas (WAZLAWICK, 1993).

\footnotetext{
${ }^{6}$ Do inglês: Partially Observable Markov Decision Process

${ }^{7}$ Do inglês: Completly Observable Partially Deterministic Environment.

${ }^{8}$ Do inglês: Partially Observable Partially Deterministic Environment.
} 


\subsubsection{Modelos baseados em transformações direta e inversa}

Uma outra vertente utilizada na proposição de modelos de esquemas é a de modelos que se utilizam de Transformações Direta e Inversa (TDI). Enquanto Drescher se utiliza da frequência de ocorrência dos estados dos sensores para encontrar os contextos e resultados do esquema gerado já com a ação predefinida, na abordagem por TDI o estado futuro dos sensores é encontrado pela transformação direta, enquanto as ações que gerarão um dado resultado são encontradas pela transformação inversa.

Usaremos o sistema MOSAIC (WOLPERT; KAWATO, 1998) como base para descrever os sistemas baseados em TDI. O sistema é composto por múltiplos pares de modelos que usam TDI. Sejam $s_{t} \in S$ os estados dos sensores do agente (sensações) no instante $t$ e $a_{t} \in A$ os estados de seus atuadores. Tem-se que:

$$
\begin{aligned}
& s_{t+1}=f\left(s_{t}, a_{t}\right) \quad \text { Transformação direta; e } \\
& a_{t}=g\left(\bar{s}_{t+1}, s_{t}\right) \quad \text { Transformação inversa. }
\end{aligned}
$$

onde: $f: S \times A \mapsto S$ representa a transformação direta; $g: S \times S \mapsto A$, a transformação inversa; e $\bar{s}_{t+1} \in S$ é a sensação que se deseja obter. Note que os modelos direto e inverso são amarrados de forma que $f$ e $g$ possuem a seguinte relação inversa:

$$
\bar{s}_{t+1}=f\left(s_{t}, g\left(\bar{s}_{t+1}, s_{t}\right)\right)
$$

Apesar do MOSAIC não utilizar o conceito de esquema propriamente dito, há a percepção de que um único modelo direto $f$ e inverso $g$ não são suficientes para mapear os comportamentos do agente em todos os contextos necessários para a interação com o ambiente. Para sanar este problema é proposta a utilização de múltiplos pares de modelos, onde cada par é treinado para responder a contextos distintos. Para isso, ao $i$-ésimo par é associado o sinal de responsabilidade $\lambda_{t}^{i}$. Este sinal é calculado com 
base nos erros de predição dos modelos diretos dos pares de forma que as maiores responsabilidades são atribuídas aos pares que melhor prevêem as situações sensórias do contexto atual. Assim, acabam especializando-se em contextos distintos. Da mesma forma, para encontrar a ação a ser executada pelo agente (ação resultante) é feita uma soma das saídas dos modelos inversos dos pares ponderadas por suas responsabilidades. Neste modelo, os módulos direto e inverso são implementados por redes neurais do tipo feed-forward e treinadas pelo algoritmo de backpropagation com gradiente descendente.

Taniguchi se utiliza do conceito de esquemas proposto por Piaget para propor um sistema composto por múltiplos módulos internos que implementam o modelo de transformação direta (TANIGUCHI; SAWARAGI, 2008). O sistema MOSAIC possui um conjunto fixo de módulos internos que são selecionados para treinamento de forma relativa, ou seja, o módulo com maior responsabilidade para tratar da situação é eleito. Já no sistema de Taniguchi os módulos internos, chamados de esquemas, são gerados de forma incremental quando o sistema percebe que nenhum dos esquemas existentes está apto a tratar a situação corrente. A decisão de se a nova experiência adquirida deve ser assimilada a um esquema pré-existente ou se deve resultar na geração de um novo esquema é feita com base na teoria da hipótese de teste ${ }^{9}$.

Um outro modelo, proposto por Tani, utiliza uma rede neural recorrente parametrizada $(\mathrm{RNNPB})^{10}$ para gerar os padrões sensórios e motores necessários para o treinamento e utilização do esquema (TANI; ITO; SUGITA, 2004). Neste modelo de rede recorrente, os biases da rede são utilizados como parâmetros $(\mathrm{PB})^{11}$ que modificarão (modularão) o comportamento (sequências sensório-motoras) da rede. Enquanto as sensações e as ações de um dado instante $\left(a_{t}, s_{t}\right)$ servem de entrada para a RNNPB, as sensações e ações no instante seguinte $\left(a_{t+1}, s_{t+1}\right)$ são lidas a partir da saída da rede

\footnotetext{
${ }^{9}$ Do inglês: Hypotesis testing theory.

${ }^{10}$ Do inglês: Recurrent Neural Network with Parametric Biases.

${ }^{11}$ Do inglês: Parametric Biases.
} 
e, caso haja retroalimentação, as saídas são reutilizadas como entrada para a próxima iteração. O treinamento e o uso do esquema é definido por três fases: (a) Fase de treinamento: os biases e a matriz de pesos da rede são ajustados utilizando-se os dados de treinamento. Para esta fase, que representa o treinamento da transformação direta, a retroalimentação não é utilizada; (b) Fase de geração: depois da rede ter sido treinada, a retroalimentação pode ser ligada para a geração de padrões sensório-motores. O vetor de biases da rede é então usado para moldar a dinâmica da geração dos padrões da rede. Note que o uso da retroalimentação permite à rede gerar sequências sensório-motoras imaginárias, ou seja, geradas pelas próprias previsões da rede. (c) Fase de reconhecimento: nesta fase o vetor de biases é calculado a partir das sequências sensórias que estão sendo fornecidas à rede. Lembrando que este vetor é usado para a modulação do comportamento da rede, seu cálculo a partir das sensações correntes pode ser encarado como um reconhecimento da forma de atuar que foi aprendida na fase de treinamento. Para que isto seja possível, já na fase de treinamento, alguns nós da rede são treinados para que suas saídas sejam utilizadas como os biases, tendo valores próximos para sequências sensórias suaves (mesmas sequências), mas valores distintos para sequências distintas. Assim, na fase de reconhecimento, os biases são reestabelecidos para as sequências (comportamentos) que foram utilizadas no treinamento.

Gläser propõe um modelo de esquema que segue a mesma linha do modelo proposto por Tani. Porém, a modulação do comportamento do sistema é feita a partir da atividade de um mapa de esquemas (GLäSER; JOUBLIN; GOERICK, 2009). Este modelo é composto por um mapa de esquemas, um reconhecedor de esquemas, um módulo de transformação direta e um módulo de transformação inversa. Diferentemente do modelo de Tani que utiliza uma única RNNPB para implementar simultaneamente os módulos de transformação direta e inversa, no modelo de Gläser o módulo direto é implementado por uma rede neural recorrente $(\mathrm{RNN})$ e o módulo inverso por uma rede feed-forward. Assim como no modelo de Tani, a modulação do comportamento da 
rede que implementa o módulo direto é feita pela modificação dos seus biases que são gerados pela atividade do mapa de esquemas. O mapa de esquemas é um mapa bidimensional onde cada elemento representa um esquema. O sistema organiza topograficamente o mapa de esquemas de forma que elementos vizinhos representam comportamentos similares e, consequentemente, possam ser usados para atingir resultados similares. Por último, há o módulo reconhecedor de esquemas. Este módulo é implementado por uma outra RNN e é responsável por mapear as observações sensórias previstas para a própria experiência com o objetivo de controlar a configuração de ativação dos esquemas que melhor descrevam as observações.

É importante notar que o modelo proposto por Gläser implementa um único nível (camada) de esquemas fazendo apenas referência à forma como podería-se implementar uma hierarquia de esquemas.

\subsection{Sobre os outros modelos baseados em esquemas}

Nesta seção destacaremos algumas questões que julgamos pertinentes aos modelos baseados em esquemas quando vistos sob o ponto de vista do DCAA e que a nosso ver devem ser consideradas quando da proposição de tais modelos.

\subsubsection{Natureza da informação do aparato sensório-motor}

A natureza dos sinais veiculados pelos sensores e atuadores dos esquemas é de fundamental importância para o enquadramento do modelo às premissas do CSN.

Nos modelos de esquema estudados, cada abordagem utiliza naturezas distintas para os sinais sensório-motores. Enquanto nos modelos baseados em itens o item é o elemento básico da informação comunicada, nos modelos baseados em TDI são utilizados sinais representados por variáveis reais.

Logo à primeira vista, podemos perceber que os modelos baseados em itens atri- 
buem explicitamente uma semântica a cada sensor e atuador do esquema. Por exemplo, um sensor é associado a um item que indica InFrontOfDoor. Este item implica em se ter um mecanismo externo ao esquema que conheça o conceito de porta, de estar em frente a algo e também que seja capaz de identificar portas quando as vir. O problema de possuir este mecanismo sofisticado, porém implícito, apesar de ser um empecílho para o CSN, não é o mais grave. O problema real está em que o esquema não possui acesso aos pormenores que formam o conceito estabelecido pelo item. O esquema não tem acesso às partes que constituem o conceito e, portanto, passa a ser incapaz de reutilizá-las para compôr outros possíveis conceitos.

Com relação ao aspecto da natureza dos sensores e atuadores, os modelos baseados em TDI apresentam uma opção mais condizente com o CSN, pois os sinais associados ao aparato sensório-motor são tidos genericamente como variáveis reais. Porém, aspectos como a exigência de continuidade topológica do espaço sensório ou motor formado pela agrupamento dos sensores também deve ser considerada para a adequação do modelo ao CSN. Neste trabalho não nos aprofundaremos na análise deste ponto. Limitaremo-nos aqui a apenas ressaltar a importância desta questão.

\subsubsection{Conexão do esquema ao aparato sensório-motor do agente}

Os esquemas são estruturas cognitivas que interagem com outras estruturas cognitivas ou com o meio externo através dos sensores e atuadores do agente. De ambas as formas, o esquema percebe o meio externo a si apenas pelas interações que realiza através de seus sensores e atuadores. Assim, a definição da dinâmica acerca da conectividade dos sensores e atuadores é de fundamental importância para o modelo de esquemas, visto que o esquema só é capaz de organizar as situações que fazem sentido dentro do espaço delimitado por seu aparato sensório-motor.

A dinâmica de conectividade dos sensores e atuadores do esquema diz respeito às regras adotadas para a definição de suas conexões ao meio externo. Nos modelos TDI 
estudados, o aparato sensório-motor do esquema coincide com o aparato do agente, ou seja, os esquemas estão conectados a todos os sensores e atuadores do agente. Já nos modelos baseados em ítens os sensores e atuadores dos esquemas são gerados pela dinâmica do próprio sistema e são acrescidos conforme as necessidades.

A abordagem que utiliza todo o aparato sensório-motor do agente refletido no aparato do esquema, apesar de cômoda, nitidamente não é escalável para agentes com um grande número de sensores e atuadores. A abordagem de crescimento dinâmico das conexões entre o aparato do esquema e o do agente parece resolver o problema, pois teríamos o aparato do esquema ajustando-se conforme as necessidades de expansão dos sistemas sensório-motores sendo organizados pelo esquema. Porém, esta expansão é possível apenas porque há independência semântica entre os distintos sensores e atuadores, como acontece nos modelos baseados em ítens, pois caso contrário, não teríamos critérios para escolher quais sensores ou atuadores adicionar.

Quando da introdução do conceito de esquema, na Seção 2.1.2, já antecipamos a possibilidade de que o aparato sensório-motor do esquema seria dado por um subconjunto do aparato sensório-motor do agente. Na Seção 3.2 veremos como esta opção é adotada pelo modelo proposto. A fixação das conexões do aparato do esquema permite sua estruturação em um espaço estável de forma que as dinâmicas sensório-motoras que se encontrem dentro deste espaço possam ser organizadas. Também, resolve-se o problema de escalabilidade do número de sensores e atuadores do agente, visto que o aparato do esquema pode estar restrito a um subconjunto destes. Porém, um novo problema surge: “como lidar com as dinâmicas sensório-motora que não se restrinjam aos espaços abarcados pelos aparatos sensório-motores dos esquemas do sistema?". Contudo, se prestarmos atenção ao fato de que o aparato do agente também não percebe todo o ambiente que o cerca, veremos que estamos apenas antecipando o problema. Ou seja, mesmo que os aparatos dos esquemas estejam completamente conectados ao aparato do agente, o problema de como organizar as dinâmicas não contidas no apa- 
rato do agente e, consequentemente do esquema, mantém-se. Vê-se, desta forma, a necessidade de estabelecer um mecanismo capaz de organizar as dinâmicas que não se atenham ao espaço abarcado pelos esquemas. Na Seção 3.3 veremos como o mecanismo de coordenação entre os esquemas apresenta uma solução para este problema.

\subsubsection{Representação das relações sensório-motoras}

Em um sistema baseado em esquemas, o esquema não somente é a unidade básica do sistema, mas também é a única estrutura utilizada na construção do sistema. Sendo assim, a representação de todo o conhecimento do sistema estará nos esquemas e em suas relações. Assim, a questão da capacidade e natureza do que pode ser representado por um único esquema é chave na compreensão das capacidades e limitações do sistema como um todo.

Uma característica constante em todos os modelos de esquema estudados (Seção 2.2) é a utilização do paradigma funcional para a representação da organização das relações sensório-motoras pelos esquemas. Neste paradigma, as ações são tidas como funções das sensações.

Nos modelos baseados em TDI, o uso do paradigma funcional é explícito, como demonstram (2.2) e (2.3). Já nos modelos baseados em itens, a utilização das ações como funções das sensações está implícita, mas pode ser notada pelo fato de que os esquemas são gerados com uma única ação a ele associada, como visto na Seção 2.2.1. Em relação à escolha da ação a ser aplicada, percebe-se que o esquema, quando ativado, opera como uma função constante, $f$, que tem por domínio o contexto do esquema, $C$, e que sempre leva à ação, $a$, associada ao esquema: $f: C \mapsto\{a\}$.

A utilização do paradigma funcional como base para a representação das relações sensório-motoras apreendidas pelos esquemas, quando adotado o paradigma do DCAA, mostra-se insuficiente para tratar de situações onde há opções distintas de atuação, dadas as mesmas situações sensórias (MUñOZ; NETTO, 2012). Também, o caráter 
determinístico da escolha da ação a ser implementada, imposto por tal paradigma, impede a utilização do esquema como elemento de representação de todas as possíveis formas de interação sensório-motoras, restringindo a representação das possíveis atuações perante as sensações percebidas.

Uma outra abordagem para a apreensão das relações sensório-motoras pelos esquemas, proposta em (MUñOZ; NETTO, 2012), é a da utilização de domínios sensóriomotores. Nesta abordagem, armazena-se um conjunto que represente os pontos sensórios e motores interessantes ao esquema, ao invés de armazenar uma função que represente suas relações.

Enquanto a abordagem funcional deixa a cargo do esquema a decisão de qual ação deve ser tomada, na abordagem por domínio esta decisão pode ser postergada a estruturas maiores, mas restringindo as decisões aos conjuntos que satisfaçam as necessidades do esquema. Por este aspecto, a abordagem por domínio mostra-se mais completa à representação das relações sensório-motoras. Na Seção 3.1.1 veremos como a abordagem por domínio é inserida no modelo proposto neste trabalho.

\subsubsection{Alcance espaço-temporal}

Seguindo o paradigma do DCAA, o sistema de esquemas é iniciado sem conhecimento algum acerca das relações causais impostas pelo ambiente externo aos seus sensores e atuadores. O esquema é a estrutura cognitiva básica responsável por estabelecer estas relações causais elementares. A expansão das relações causais elementares tanto no espaço quanto no tempo é um dos pontos-chave para o desenvolvimento do sistema.

Por sua natureza, o esquema define a maior resolução de causa e efeito que o sistema é capaz de perceber. Quando o esquema se restringe a esta causalidade ínfima podemos dizer que ele está fazendo o papel de um átomo de causalidade. 
Dito de outra forma, o átomo define a unidade de causalidade percebida pelo sistema e, por isso, não é tido como estrutura cognitiva. O esquema, por outro lado, composto por átomos de causalidade, é visto como a unidade cognitiva do sistema.

Quanto menor a granularidade espaço-temporal que o esquema consiga captar, mais determinística é a relação causal percebida através de seus sensores e atuadores ${ }^{12}$

O treinamento dos esquemas é facilitado quando as relações causais que ele deve apreender são determinísticas e lineares, o que pode ser assumido para relações causais curtas nos sentidos espacial e temporal. Porém, conforme ampliamos o alcance tanto espacial quanto temporal das relações causais, mais difícil se torna para uma única unidade cognitiva apreendê-las.

A capacidade de apreensão da causalidade para relações espaço-temporais mais distantes é alcançada pelo encadeamento dos esquemas gerando uma rede (grafo) de esquemas. Assim, as bifurcações e reencontros dos caminhos observados podem ser refletidos pelos grafos de esquemas criados internamente pelo sistema. Porém, apesar da ampliação da capacidade de apreensão para causalidades não-lineares, os grafos de esquemas ainda não são capazes de transpor a barreira da percepção imediata. Os grafos ainda estão restritos à percepção sensória imediata e por ela são regidos.

A ampliação do alcance espaço-temporal das relações causais cujos elementos estão sempre presentes nas percepções sensoriais diretas do agente para aquelas que dependem de elementos que em dado momento podem não ser percebidos exige a utilização de mecanismos mais sofisticados.

\footnotetext{
12 Podemos aqui fazer um paralelo à aproximação matemática de uma função não linear por segmentos lineares.
} 


\section{MODELO TEÓRICO PROPOSTO}

Este capítulo é dedicado à exposição do modelo teórico do sistema de esquemas proposto. A implementação computacional do modelo se encontra no Capítulo 4.

O modelo proposto segue o paradigma do DCAA sendo concebido para ser utilizado como o sistema cognitivo de um agente computacional a ser inserido em algum ambiente não conhecido de antemão pelo projetista do sistema. A interação do agente com seu meio externo é tida como a base para a construção de suas estruturas cognitivas. Neste aspecto, um dos desafios do sistema cognitivo é o de encontrar as coerências do meio no qual foi inserido que possam lhe ser útil, de alguma forma. Ou, de outra maneira, o sistema é concebido tendo como mecanismo intrínsico a organização das relações sensório-motoras encontradas pelas interações com o meio.

A Seção 3.1 descreve o átomo de causalidade, conceito utilizado para representar a unidade atômica do sistema quanto à organização das relações sensório-motoras de menor granularidade espaço-temporal que o sistema pode conceber, ou seja, os átomos representam a causalidade ínfima e são utilizados como estruturas básicas para compor o esquema.

A seguir, na Seção 3.2 o modelo de esquema cognitivo é apresentado. O esquema proposto é composto por átomos causais que compartilham os mesmos sensores e atuadores. O esquema se estrutura como um grafo causal capaz de lidar com causalidades não-lineares, mas que ainda se restringem à percepção imediata. Outra limitação do esquema proposto diz respeito ao alcance espacial, visto que assume-se que seus sen- 
sores e atuadores são subconjuntos dos sensores e atuadores do agente.

Apesar do foco do trabalho estar no esquema, o modelo teórico foi pensado um pouco além deste. As Seções 3.3, 3.4 e 3.5 que estendem o modelo teórico seguem na direção da extrapolação da percepção sensório-motora imediata caminhando para a aquisição autônoma da noção de objeto e se preocupam, respectivamente com: a unificação do espaço sensório-motor de diferentes esquemas; com a hierarquização dos esquemas; e com suas capacidades de generalização. Esta parte da pesquisa que extrapola o esquema é importante principalmente para contextualizar e definir as características do modelo de esquema proposto quando pensado como parte de um sistema mais amplo.

\section{1 Átomo de causalidade}

O átomo de causalidade é a estrutura básica do sistema, ou seja, todo o sistema cognitivo é construído o tendo como base. Em especial, o átomo é a estrutura fundamental para a construção do esquema que representa a unidade cognitiva do sistema. A principal característica do átomo de causalidade é que sua estrutura é rígida e bem definida, assim como o papel que ela desempenha perante o sistema.

A estrutura do átomo de causalidade segue o modelo de esquema proposto por Drescher com a diferença de que sua responsabilidade temporal de previsão é sempre a do menor instante de tempo concebido pelo sistema. Um outro ponto importante é que a sedimentação do conhecimento apreendido pelo átomo é representado utilizando a abordagem por domínio sensório-motor que será apresentada na Seção 3.1.1 ao invés da abordagem funcional utilizada pelos modelos de esquema estudados, já apresentados na Seção 2.3.3.

O átomo de causalidade tem a função de apreender as relações causais tidas por ele como imediatas. Ou seja, ele é a ponte entre a aplicação de uma ação à situação 
sensória corrente e próxima situação sensória percebida, não se importando com as possíveis modificações que possam ter ocorrido, mas não percebidas, nesse ínterim. Visto que há uma ligação entre o ponto sensório corrente e o ponto sensório futuro considerando o menor intervalo de tempo possível, sua previsão pode ser considerada linear e infinitesimal sob o ponto de vista das capacidades do sistema. Também, por sua simplicidade estrutural, que será vista mais adiante, o átomo restringe-se à apreensão de mudanças determinísticas.

No modelo proposto a essência do esquema está no átomo de causalidade, representado por $Q$, e que expressa a seguinte relação:

$$
Q_{S} \stackrel{Q_{A}}{\rightarrow} Q_{O}
$$

onde: $Q_{S} \subseteq S$ é o contexto sensório do átomo; $Q_{A} \subseteq A$, seu contexto motor; e $Q_{O} \subseteq S$, seu objetivo sensório. Note que a diferença entre a relação aqui proposta e a apresentada em (2.1) é que ao invés de restringir o esquema a uma única ação estamos permitindo o uso de um conjunto de ações que podem ser aplicadas para atingir o resultado previsto pelo esquema. Outro ponto é que denominaremos de objetivo sensório o que no modelo de Drescher é denominado de resultado.

A relação expressa em (3.1) indica que dada uma sensação $s_{t} \in Q_{S}$, se uma ação $a_{t} \in Q_{A}$ for aplicada aos atuadores do esquema ao qual o átomo pertence, então $s_{t+1} \in$ $Q_{O}$.

A seguir definiremos a estrutura do átomo de causalidade e logo após mostraremos como ela pode ser utilizada pelo sistema.

\subsubsection{Representação por domínio sensório-motor}

Ao invés de utilizarmos a abordagem funcional para armazenar a representação da relação entre sensações e ações, adotaremos a abordagem por domínio sensóriomotor. Nesta abordagem, não é a relação entre as sensações e as ações o que importa, 
mas sim quais pares de sensações e ações (situações sensório-motoras) são capazes de produzir os resultados considerados pertinentes. Assim, todas as situações sensóriomotoras que levam à obtenção de situações sensórias contidas no objetivo do átomo são incluídas no conjunto que representa o contexto sensório-motor do átomo.

No modelo proposto, a estrutura do átomo de causalidade é dada por um conjunto de situações sensório-motoras denominado contexto sensório-motor representado por $Q \subseteq S \times A$. Note que o conceito de átomo de causalidade, sua estrutura e seu contexto sensório-motor estão sendo representados por $Q$.

Dadas a sensação $s_{t} \in S$ e a ação $a_{t} \in A$ no instante de tempo $t \in \mathbb{N}$, o contexto sensório-motor do átomo é dado por ${ }^{1}$ :

$$
Q=\left\{\left[s_{t}, a_{t}\right] \in S \times A \mid \exists s_{t+1} \in Q_{O} \wedge s_{t} \stackrel{a_{t}}{\rightarrow} s_{t+1},\right\}
$$

onde: $S$ é o espaço sensório do esquema ao qual o átomo de causalidade pertence; $A$, o espaço motor; e $Q_{O} \subseteq S$, o objetivo sensório do átomo. A Figura 1 representa esta relação.

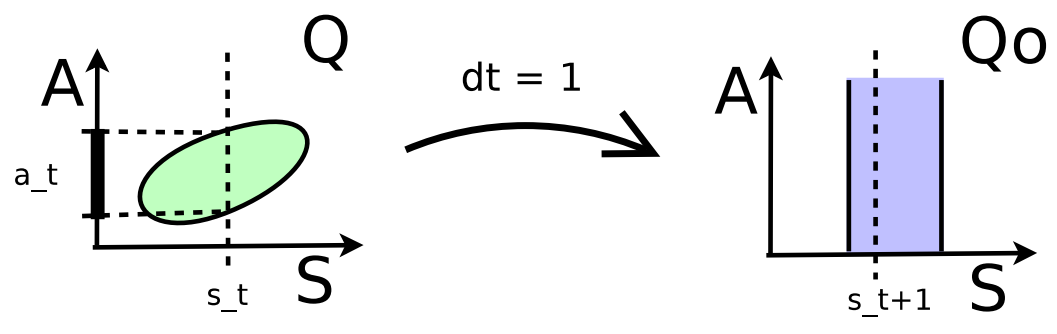

Figura 1: Representação gráfica do conjunto que representa o contexto sensório-motor de um átomo de causalidade e sua relação com seu objetivo sensório.

A seguir veremos como a estrutura do átomo de causalidade é utilizada para gerar suas funcionalidades.

\footnotetext{
${ }^{1}$ A notação $\left[a_{t}, s_{t}\right]$ representa a concatenação dos vetores $a_{t}$ e $s_{t}$.
} 


\subsubsection{Funcionalidade}

Como dito anteriormente, o átomo de causalidade armazena em seu contexto sensório-motor $Q$ o conjunto dos pares de sensações e ações (situações sensóriomotoras) que levam à obtenção de sensações pertencentes ao seu objetivo. Repare que $Q$ previlegia a representação e que, por isso, não fornece diretamente as ações que podem ser utilizadas pelo átomo (contexto motor) nem as sensações que o excitam (contexto sensório) e nem as sensações que o motivam (objetivo sensório). Nesta seção veremos como obtê-las.

Um ponto importante a ser ressaltado é que, diferentemente dos esquemas que se utilizam da abordagem funcional onde para cada sensação existe apenas uma única ação correspondente, na abordagem por domínio sensório-motor, para cada sensação há um conjunto de ações correspondentes.

O conjunto de ações sugeridas depende da sensação corrente. Dada a sensação $s_{t} \in S$, o conjunto de ações sugeridas pelo átomo $Q$ é obtido por:

$$
Q_{A}\left(s_{t}\right)=\left\{a_{t} \in A \mid\left[s_{t}, a_{t}\right] \in Q\right\} .
$$

Os átomos de causalidade são estruturas pensadas para funcionar de forma dependente do sistema no qual estão inseridos. Assim, o objetivo sensório dos átomos não é armazenado em suas próprias estruturas, mas nas estruturas das entidades às quais eles se associam. Note que a relação do átomo com a entidade que armazena seu objetivo é bastante modular. Ao átomo interessa saber se as situações sensório-motoras definidas por ele levam ou não ao objetivo, deixando a cargo de outras estruturas armazenar o que exatamente significa este objetivo. Veremos mais adiante, na Seção 3.2.3, que os átomos associam-se a outros átomos na composição do esquema, e que o contexto sensório-motor de um gera o objetivo sensório do outro.

O contexto sensório de um átomo, $Q_{S}$, é dado pela projeção de seu contexto 
sensório-motor no espaço sensório:

$$
Q_{S}=\operatorname{proj}_{S}(Q)
$$

Note que por (3.2), (3.3) e (3.4) temos que se uma sensação, $\bar{s}$, pertence ao contexto sensório do átomo, então o átomo é capaz de sugerir uma ação, $\bar{a}$, que leva a uma outra sensação, $s^{*}$, contida no objetivo do átomo, $Q_{O}$. Ou seja:

$$
\bar{s} \in Q_{S} \Rightarrow \exists \bar{a} \in Q_{A}(\bar{s}) \mid[\bar{s}, \bar{a}] \in Q \Rightarrow \exists s^{*} \in Q_{O} \wedge \bar{s} \stackrel{\bar{a}}{\rightarrow} s^{*}
$$

Esta relação entre as sensações do contexto sensório e o contexto motor do átomo embora óbvia é importante, pois expressa quando e como os átomos interagem com o meio externo ${ }^{2}$.

A seguir veremos como os átomos de causalidade modificam seus estados, utilizados pelo esquema para compôr sua estrutura.

\subsubsection{Estados}

Dependendo da sensação corrente $s_{t}$, os átomos de causalidade $Q$ podem estar em três diferentes estados:

Excitado: $Q$ é tido como excitado quando a situação $s_{t}$ pertence ao contexto sensório $Q_{S}$ de $Q:$

$$
s_{t} \in Q_{S}
$$

Ativado: $Q$ é tido como ativado quando a situação sensória $s_{t}$ e a situação motora $a_{t}$ formam a situação sensório-motora $x_{t}=\left[s_{t}, s_{t}\right]$ de forma que:

$$
x_{t}=\left[s_{t}, a_{t}\right] \in Q
$$

Inócuo: $Q$ é tido como inócuo se a situação $s_{t}$ não é contemplada por seu contexto

\footnotetext{
${ }^{2}$ Note também que por (3.2), se $\bar{s}=s_{t}$, então $s^{*}=s_{t+1}$.
} 
sensório:

$$
s_{t} \notin Q_{S}
$$

Note que se $Q$ está no estado excitado, por (3.5) tem-se que: $a$ ) ele pode ser ativado, pois por (3.3) $\exists a \in Q_{A}(s)$; e $b$ ) se $Q$ for ativado, então seu objetivo $Q_{O}$ será alcançado conforme a capacidade que $Q$ tenha de representar as relações que levam a $Q_{O}$.

\subsection{Esquema cognitivo}

O modelo de esquema proposto tem como principal consequência de sua organização estrutural a expansão do alcance das previsões espaço-temporal captadas pelos átomos de causalidade que o compõem. Enquanto o átomo de causalidade capta e armazena as observações sensório-motoras que podem ser representadas por relações

determinísticas tendo como base o menor intervalo temporal possibilitado pelo sistema, o esquema tem a função de expandir estas relações para captar e armazenar composições destas relações, porém ainda determinísticas.

Enquanto o átomo de causalidade é a unidade que representa as relações causais ínfimas, o esquema é a unidade cognitiva do sistema. A principal característica que nos permite chamar o esquema de unidade cognitiva é sua capacidade de armazenar e propôr planos de ação perante distintas situações sensórias, armazenando também as modificações sensórias esperadas quando da efetivação destes planos de ação.

No modelo proposto, o esquema é um grafo direcionado cujos nós são átomos de causalidade e os arcos representam as relações causais entre eles. O esquema é uma estrutura que se constrói de forma autônoma com base em um objetivo sensório, um espaço sensório e um espaço motor dados a priori.

Todos os átomos de um esquema compartilham o mesmo espaço sensório-motor. Note que cada esquema utiliza apenas um subconjunto do espaço sensório-motor do 
agente. Seguindo (PIAGET, 1936), apenas em um momento posterior às organizações individuais dos esquemas, seus subespaços serão coordenados organizando o espaço sensório-motor do agente como um todo coeso. Note também que este mecanismo representa uma abordagem bottom-up de organização sensório-motora.

O crescimento do grafo sensório-motor que representa o esquema se dá pela inserção de átomos de causalidade à estrutura pré-existente. Quando são inseridos, os átomos são encadeados a algum nó pré-existente. Os átomos também podem sofrer os processos de divisão e fusão. Estes processos permitem a formação e manutenção do grafo que representa o esquema mantendo-o alinhado com as relações causais determinadas pelos espaços sensório e motor do esquema.

Nesta seção, partiremos da definição de alguns conceitos básicos que nos permitirão expôr os mecanismos utilizados na construção do grafo. Analisaremos, então, como o modelo de esquema proposto é condizente com as premissas do DCAA mesmo tendo seu objetivo e espaços sensório e motor dados a priori. Por último, as características do esquema são analisadas tendo em vista a capacidade de extrapolação da organização das dinâmicas determinadas exclusivamente pelos espaços sensório e motor do esquema.

\subsubsection{Estrutura}

A estrutura computacional do esquema é dada por um grafo sensório-motor construído com base em um objetivo sensório $E^{*}$, um espaço sensório $S$ e um espaço motor A. Assim, definiremos a estrutura do esquema como:

$$
E=\left[S, A, E^{*}, \bar{Q}, \bar{R}\right]
$$

onde: $S$ é o espaço sensório do esquema; $A$ é o espaço motor do esquema; $E^{*} \subseteq S$ é o objetivo sensório do esquema; $\bar{Q}=\left\{Q^{i}\right\}_{i=1, \ldots, E_{N}}$ é o conjunto dos $E_{N}>0$ nós do grafo; $\bar{R}=\left\{R_{i j}\right\}_{i=1, . ., E_{N} ; j=0, . ., E_{N}}$ representa as relações entre os nós do grafo sendo que 
$R_{i j} \in\{0,1\}$ indica que $Q^{i}$ está associado a $Q^{j}$ quando $R_{i j}=1, j>0$, e $R_{i 0}$ representa as relações de $Q^{i}$ a $E^{*}$.

\subsubsection{Processo de desenvolvimento}

Nesta seção veremos como o grafo que representa o esquema se desenvolve. Os processos de encadeamento entre dois átomos, de treinamento, de divisão e de fusão são aqui utilizados, embora seus detalhamentos sejam feitos nas seções seguintes, juntamente com o procedimento de treinamento dos átomos.

O algoritmo da Figura 2 detalha o processo de desenvolvimento dos esquemas, onde: EncadeiaAtomo(a,b): encadea o átomo $b$ ao átomo $a$; Divisão(a): divide o átomo $a$, cujo contexto sensório-motor é desconexo, em átomos cujos contextos sensório-motores são conexos; e $\mathbf{F u s a ̃ o A t o m o ( a , b ) : ~ f u n d e ~ o ~ a ́ t o m o ~} b$ ao átomo $a$. Note que os procedimentos TreinaAtomos() (Figura 3) e ReestruturaGrafo() (Figura 4) referenciados no algoritmo da Figura 2 são detalhados separadamente, apenas por questões estéticas.

\subsubsection{Encadeamento}

Quando o esquema é criado, associa-se ao seu objetivo sensório $E^{*}$ o primeiro átomo de causalidade, $Q^{1}$. Esta relação é representada em $\bar{R}$ por $R_{10}=1$. A associação de $Q^{1}$ a $E^{*}$ implica que $Q^{1}$ terá $E^{*}$ como seu objetivo sensório, ou seja, $Q_{O}^{1}=E^{*}$. Após esta associação, $Q^{1}$ é treinado para que as situações sensório-motoras classificadas por seu contexto sensório-motor levem a sensações contidas em $E^{*}$, ou seja:

$$
Q_{S}^{1} \stackrel{Q_{A}^{1}}{\rightarrow} E^{*}
$$




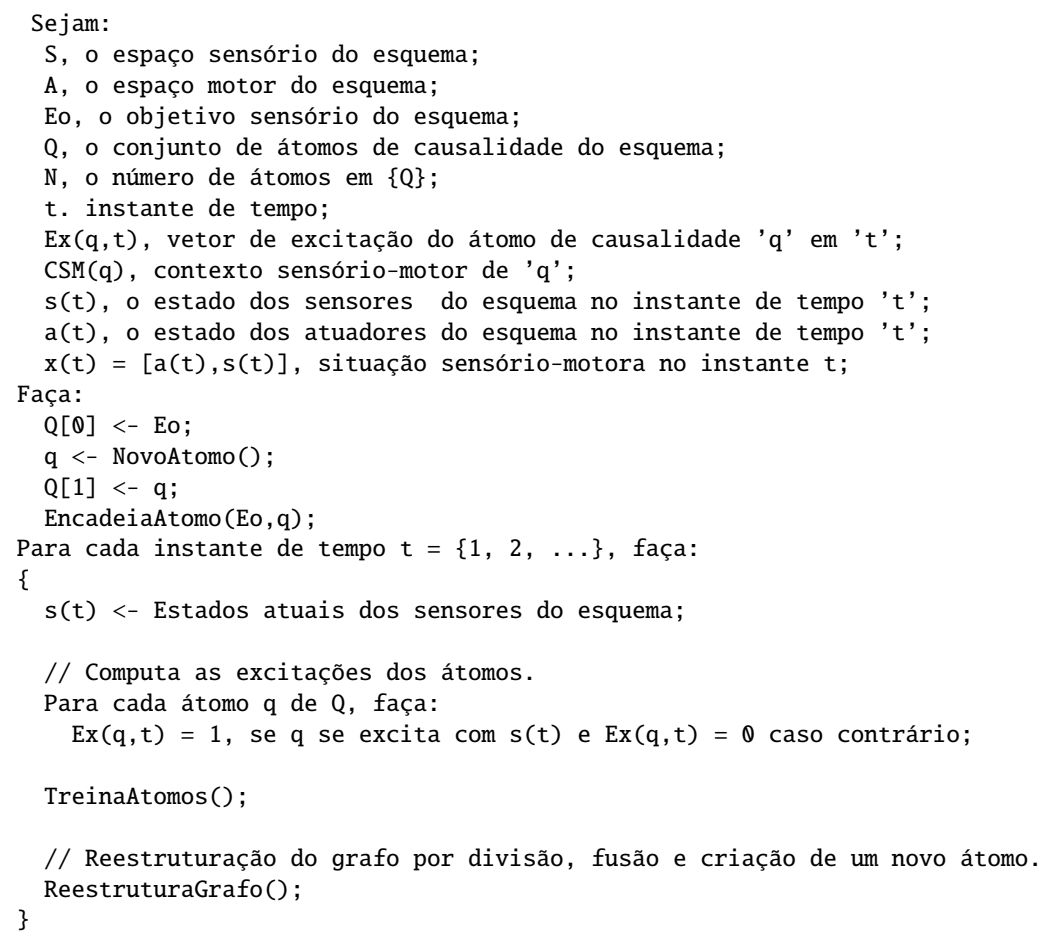

Figura 2: Algoritmo de desenvolvimento dos esquemas.

O processo de treinamento é definido com mais detalhes na próxima seção. Por hora, é importante notar que como $Q^{1}$ está conectado a $E^{*}$, temos que:

$$
s_{t} \in Q_{S}^{1} \Rightarrow \exists a \in Q_{A}^{1}\left(s_{t}\right) \mid s_{t} \stackrel{a}{\rightarrow} s_{t+1} \wedge s_{t+1} \in E^{*}
$$

Em poucas palavras, se a sensação corrente $\left(s_{t}\right)$ pertence ao contexto sensório do átomo $\left(Q_{S}^{1}\right)$, então há uma ação $(a)$ dada pelo contexto motor do átomo $\left(Q_{A}^{1}\left(s_{t}\right)\right)$ que leva a uma sensação contida no objetivo do esquema $\left(E^{*}\right)$. Seguindo a construção do esquema, após $Q^{1}$ atingir o estado treinado, um novo átomo $\left(Q^{2}\right)$ é a ele associado, implicando que o objetivo de $Q^{2}$ será dado pelo contexto sensório de $Q^{1}$, ou seja, faz-se $Q_{O}^{2}=Q_{S}^{1}$. Desta forma, temos o seguinte encadeamento:

$$
Q_{S}^{2} \stackrel{Q_{A}^{2}}{\rightarrow} Q_{S}^{1} \stackrel{Q_{A}^{1}}{\rightarrow} E^{*}
$$

A Tabela 2 ilustra os processos de encadeamento dos átomos. 


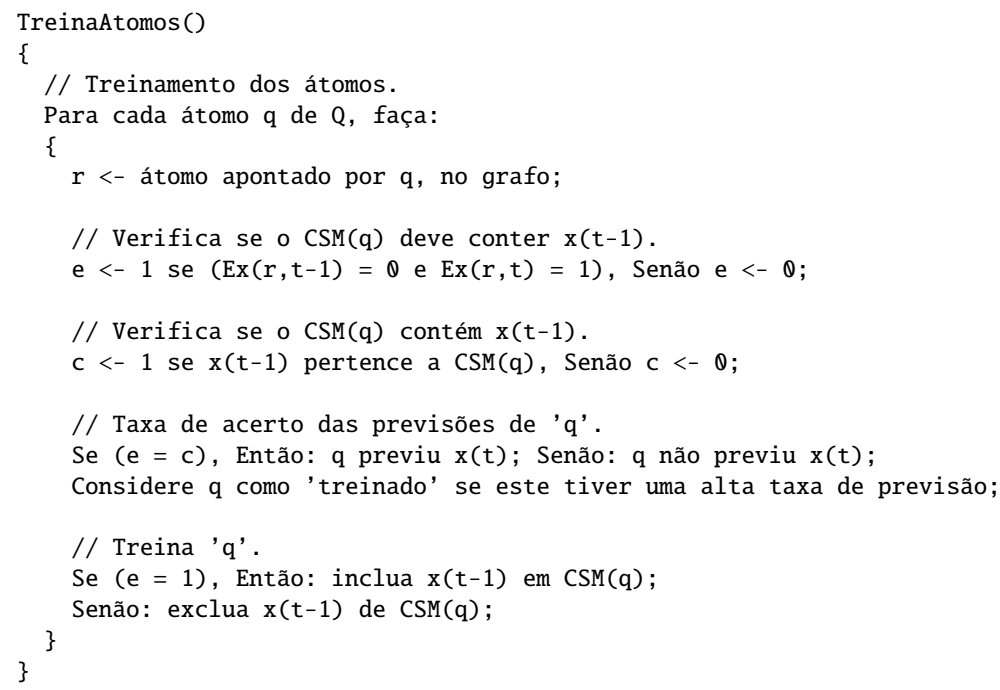

Figura 3: Algoritmo do procedimento de treinamento dos átomos. Veja as variáveis declaradas no algoritmo da Figura 2.

\begin{tabular}{|l|c|c|}
\hline Representação gráfica: & (0) & \\
\hline Conjuntos sensórios e motores: & $Q_{S}^{1} \stackrel{Q_{A}^{1}}{\rightarrow} E^{*}$ & $Q_{S}^{2} \stackrel{Q_{A}^{2}}{\rightarrow} Q_{S}^{1} \stackrel{Q_{A}^{1}}{\rightarrow} E^{*}$ \\
\hline Sensações e ações: & $s_{t} \stackrel{a_{t}}{\rightarrow} s_{t+1} \in E^{*}$ & $s_{t} \stackrel{a_{t}}{\rightarrow} s_{t+1} \stackrel{a_{t+1}}{\rightarrow} s_{t+2} \in E^{*}$ \\
\hline
\end{tabular}

Tabela 2: Encadeamento do átomo de causalidade $Q^{1}$ com o objetivo $E^{*}$ (coluna central), e o encadeamento com a inclusão de $Q^{2}$ associado a $Q^{1}$ (coluna da direita).

\subsubsection{Treinamento}

O treinamento do átomo de causalidade $Q^{i}$ é feito pela inclusão ou exclusão de uma situação sensório-motora ao contexto sensório-motor de $Q^{i}$. Perceba que a estrutura de $Q^{i}$ é dada por apenas uma classe que representa seu contexto sensório-motor (Seção 3.1.1). Por comodidade usaremos $Q^{i}: S \times A \mapsto\{0,1\}$ como função para nos referirmos ao contexto sensório-motor do átomo de causalidade sendo: 


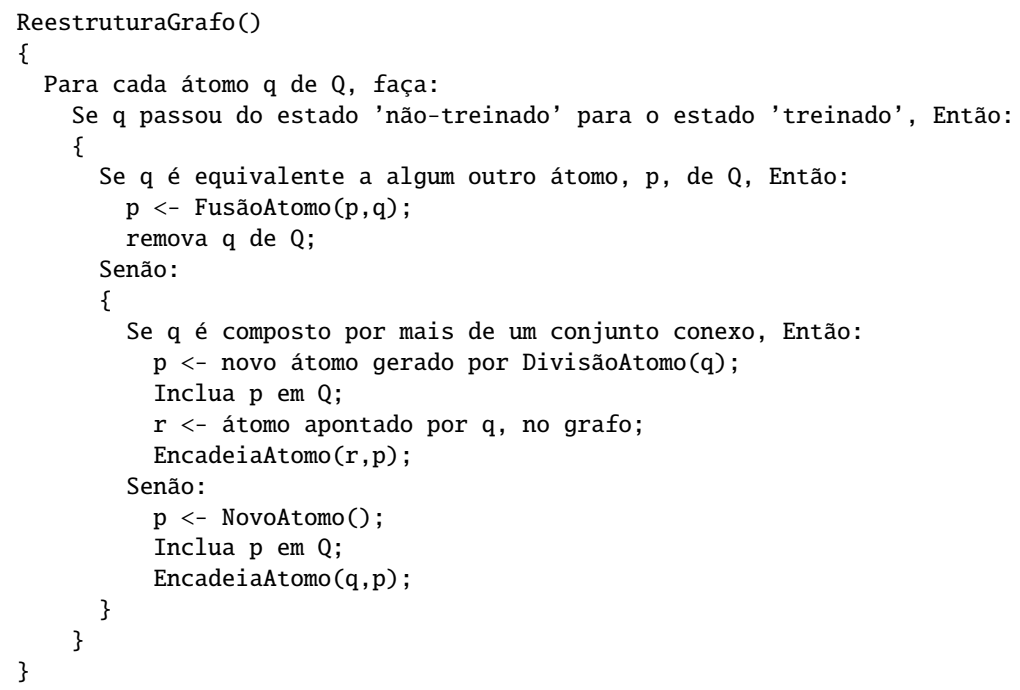

Figura 4: Algoritmo do procedimento de reestruturação do grafo. Veja as variáveis declaradas no algoritmo da Figura 2.

$$
Q^{i}([s, a])=1 \Leftrightarrow[s, a] \in Q^{i} .
$$

O treinamento de $Q^{i}$ é feito com base nas situações sensório-motoras do instante anterior ao corrente. Seja $x_{t}=\left[s_{t}, a_{t}\right] \in S \times A$ a situação sensório-motora no instante de tempo $t \in \mathbb{N}$, o treinamento de $Q^{i}$ é dado por:

$$
Q^{i}\left(x_{t} 1\right)= \begin{cases}1, & \operatorname{Se} \exists j \mid R_{i j}=1 \wedge s_{t 1} \notin Q_{S}^{j} \wedge s_{t} \in Q_{S}^{j} \\ 0, & \text { Caso contrário. }\end{cases}
$$

Em outras palavras, se a sensação corrente $s_{t}$ pertence ao contexto sensório de um átomo ao qual $Q^{i}$ está conectado e a sensação imediatamente anterior $s_{t}{ }_{1}$ não pertencia a ele, então a classe $Q^{i}$ é treinada para incluir a situação sensório-motora anterior, $x_{t}{ }_{1}$. Caso contrário, a classe é treinada para excluir $x_{t}{ }_{1}$ de $Q^{i 3}$.

Note que o processo de treinamento e a forma de encadeamento garantem que, se $Q^{i}$ está associado a $Q^{j}$, então o contexto sensório-motor de $Q^{i}$ armazenará todas as

\footnotetext{
${ }^{3}$ A forma como a classe é treinada depende de sua implementação computacional. Por exemplo, pode-se utilizar o treinamento por gradiente descendente se a classe for implementada por uma rede neural artificial.
} 
situações sensório-motoras que, quando utilizadas no instante de tempo $t$ levam a uma sensação capaz de chavear o estado do átomo $Q^{j}$ de não-excitado, no instante $t$, para excitado, no instante $t+1$.

Todos os átomos de causalidade que compõem o esquema são treinados a cada instante de tempo, incluindo ou excluindo as situações sensório-motoras conforme seus objetivos particulares são ou não atingidos. A partir de uma certa taxa de acertos o átomo pode ser considerado como treinado. A grande consequência da aquisição do status de treinado por um átomo é que a classe que representa seu contexto sensóriomotor passa a ser considerada como estável e confiável para que a estrutura do esquema possa ser construída tendo-o também como referência.

A forma exata com que um átomo de causalidade pode atingir o status de treinado depende da implementação, descrita no Capítulo 4. Porém, na descrição do modelo teórico este conceito será utilizado para disparar ações relativas à construção do grafo do esquema.

Vistas as bases para o encadeamento dos átomos de causalidade e a forma como eles são treinados, veremos a seguir o processo pelo qual um átomo pode gerar outros átomos.

\subsubsection{Divisão}

Apenas com o processo de encadeamento a estrutura do grafo ficaria restrita a uma lista de átomos de causalidade. Porém, em decorrência do algoritmo de treinamento a classe que representa o contexto sensório-motor do átomo pode acabar sendo representada por subconjuntos desconexos. Estes subconjuntos da classe são interpretados como categorias de situações sensório-motoras distintas com identidade sensóriomotora própria. Desta forma, os contextos sensório-motores $Q^{i}$ desconexos dos átomos associados a um átomo $Q^{j}$ e tidos como treinados são divididos em subconjuntos conexos $Q_{k}^{i}$ de forma que: $Q^{i}=\bigcup_{k}^{K}{ }^{1} Q_{k}^{i}$. Como consequência, ao invés de ter apenas um 
átomo $Q^{i}$ associado a $Q^{j}$ por $Q_{O}^{i}=Q_{S}^{j}$ tem-se agora $K$ átomos $\left\{Q^{i+k}\right\}_{k<K}$ associados a $Q^{j}$, todos tendo o mesmo contexto sensório como objetivo: $Q_{O}^{i+k}=Q_{S}^{j}, k=0, \ldots, K \quad 1$.
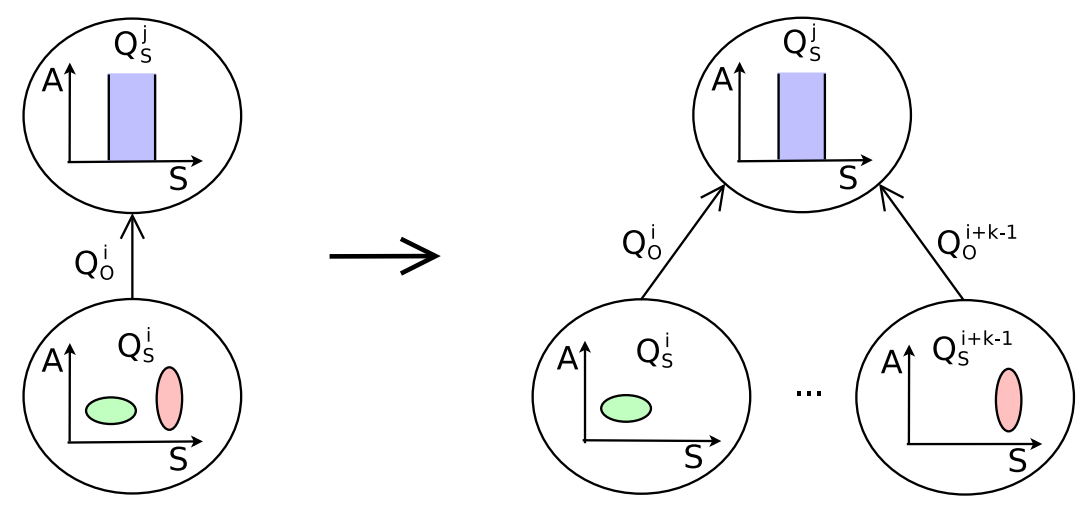

Figura 5: Ilustração do processo de divisão do átomo de causalidade $Q^{i}$ que após treinado representa uma classe composta por $K$ subconjuntos desconexos. Note que todos os $K$ novos átomos passam a se relacionar com o mesmo contexto sensório original, ou seja: $Q_{O}^{i+k}=Q_{S}^{j}, k=0, \ldots, K \quad 1$.

A Figura 5 representa o processo de divisão. Note que o processo de divisão permite que a estrutura do esquema que estava limitada a uma lista possa ser representada por uma árvore computacional.

O processo de modificação das estruturas computacionais que representam os contextos sensório-motores dos átomos e o status de treinado dos átomos resultantes $\left\{Q^{i+k}\right\}_{k<K}$ após o procedimento de divisão são considerados decisões de implementação sendo abordados no Capítulo 4.

A seguir veremos outro processo fundamental para a construção do grafo que representa o esquema, o processo de fusão dos átomos.

\subsubsection{Fusão}

Pelos procedimentos de encadeamento e de divisão, quando um átomo atinge o status de treinado um ou mais novos átomos podem ser gerados. Apenas com estes procedimentos, pode-se intuitivamente perceber que a estrutura do esquema cresceria indefinidamente. Este crescimento indefinido é estancado pelo mecanismo de fusão. 
O crescimento indefinido ocorre quando há ciclos no grafo que representa as relações causais. Um exemplo simples de ciclo pode ser percebido quando há relações causais reversas que serão utilizadas para ilustrar o procedimento de fusão.

Dado o contexto sensório $A$ que pode ser levado ao contexto sensório $B$ pelas ações $M_{A B}$, se existem ações $M_{B A}$ que levam as situações de $B$ de volta às situações expressas por $A$, dizemos que $A$ e $B$ possuem as relações reversas $M_{A B}$ e $M_{B A}$. A Figura 6 representa este cenário.

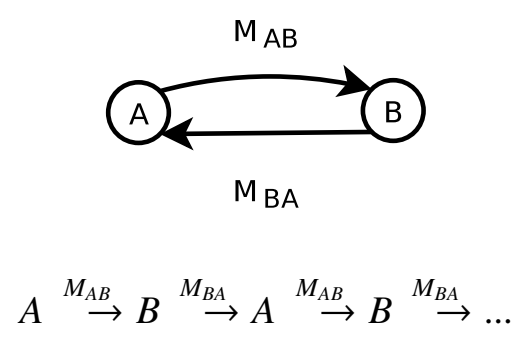

Figura 6: Representações gráfica e causal de situações onde há reversibilidade sensório-motora. As ações $M_{A B}$ levam as sensações de $A$ para sensações em $B$ e as ações $M_{B A}$ levam as sensações de $B$ para sensações em $A$. O ciclo $A \leftrightarrow B$ faz com que o grafo que representa o esquema cresça indefinidamente, como mostra o encadeamento.

O problema em questão é o da deteção dos contextos sensório-motores idênticos. Identificando-os, pode-se reestruturar o grafo de forma que ele represente corretamente os ciclos. A deteção da equivalência entre dois contextos sensório-motores é apresentada no Capítulo 4, pois depende da forma com que o esquema e os átomos são implementados. O seguinte enunciado resume o processo de fusão:

Quando os átomos $Q^{i}$ e $Q^{k} \operatorname{com} i<k$ são detetados como equivalentes $\left(Q_{S}^{i} \subseteq Q_{S}^{k} \wedge Q_{S}^{i} \supseteq Q_{S}^{k}\right)$ os átomos que têm $Q_{S}^{k}$ como objetivo passam a ter $Q_{S}^{i}$ como objetivo e $Q^{k}$ é removido do grafo.

Para exemplificar o procedimento de fusão, imagine que o esquema tem como objetivo fazer o agente se posicionar em cima de um objeto. O esquema possui 4 sensores que indicam a posição do objeto relativa ao corpo do agente. O esquema 
percebe se o objeto está à sua frente, ao lado direito, esquerdo, ou às suas costas, pelos estados dos sensores $\{f, d, e, c\}$, respectivamente. O agente que se utiliza do esquema possui o sensor $x$ que indica se o agente está ou não em cima do objeto.

O esquema pode comandar o agente virando-o à direita, à esquerda ou andando para frente, pelas ações $\{D, E, F\}$, respectivamente ${ }^{4}$. A Figura 7 ilustra o processo de fusão proposto.
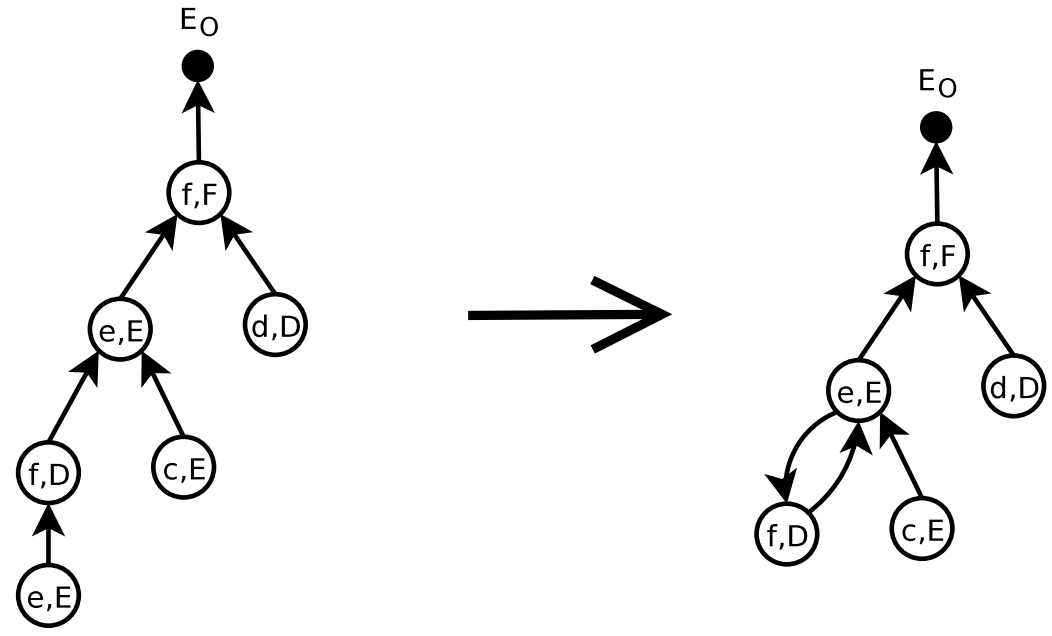

Figura 7: Ilustração do processo de fusão. No grafo à esquerda, os átomos com contexto sensório-motor $[e, E]$ foram detetados como sendo equivalentes. $\mathrm{O}$ grafo resultante é mostrado à direita. Note que o átomo $[e, E]$ mais recente (quarto nível) é eliminado e suas associações são transferidas ao átomo $[e, E]$ mais antigo (segundo nível).

No grafo da esquerda na Figura 7, se o objeto estiver na frente (contexto sensório $f$ ) do agente e o agente andar para frente (contexto motor $F$ ), então o objetivo do esquema é atingido. Isto é representado pelo contexto sensório-motor do primeiro átomo: $[f, F]$. Agora perceba que os contextos $e$ e $f$ possuem as relações reversas $E$ e D. Ou seja: $e \stackrel{E}{\rightarrow} f \stackrel{D}{\rightarrow} e \stackrel{E}{\rightarrow}$..., como ilustrado no grafo. A presença da relação reversa é detetada, no exemplo, pela equivalência dos dois átomos representados por $[e, E]$. O grafo à direita mostra o grafo resultante após o processo de fusão. Note que a aplicação da ação $E$ ao contexto sensório $e$, leva simultaneamente à ativação dos átomos $[f, F] \mathrm{e}$

\footnotetext{
${ }^{4}$ Note a semelhança com o modelo de ítens utilizado por Drescher. Porém, é importante deixar claro que este é um exemplo ilustrativo utilizado para o melhor entendimento do procedimento de fusão e que os átomos do modelo proposto não lidam com ítens, mas com sinais representados por conjuntos de números reais.
} 
$[f, D]$, pois seus contextos sensórios são idênticos.

Um ponto interessante a ressaltar é que o objetivo do esquema, $E^{*}$, é associado ao estado true do sensor $x$ do agente e que este sensor não precisa, necessariamente, fazer parte do contexto sensório do esquema, pois apenas o estado do objeto $E^{*}$ é utilizado pelo esquema.

\subsubsection{Sobre os objetivos}

O esquema é originado tendo um objetivo sensório dado a priori. Todos os átomos que compõem o grafo do esquema são gerados tendo o objetivo como motivo. O grafo resultante, construído em torno do objetivo, é composto por todas as situações sensório-motoras determinísticas que levam à obtenção de alguma sensação contida no objetivo original. Desta forma, o grafo parece ser resultante do objetivo que o originou. Porém, nossa visão é a de que o objetivo é apenas um pretexto para a elaboração de um grafo sensório-motor que representa as formas de interação do agente com o meio que também poderiam ter surgido mesmo que outro objetivo tivesse sido dado ${ }^{5}$. Ou seja, independentemente do objetivo inicial, o grafo sensório-motor que representa as relações determinísticas fundamentais e passíveis de serem organizadas pelo esquema acabarão sendo constituidas.

Assumindo que o objetivo dado a priori é apenas um pretexto para o engendramento das relações determinísticas a que o aparato sensório-motor do esquema presencia, temos que o compromisso com o DCAA mantém-se, mesmo sendo o objetivo do esquema dado a priori. Porém, é importante termos sempre em vista a natureza do objetivo do qual estamos falando. O objetivo é um subconjunto dos estados dos sensores do esquema, mesmo que estes sejam gerados por outros estados do agente que não tenham conexão alguma com o espaço sensório do esquema. Perceba que mesmo

\footnotetext{
${ }^{5}$ Desde que o objetivo dado pertença ao contexto sensório de algum átomo do grafo e haja algum caminho no grafo entre os átomos diretamente associados ao objetivo que forma o grafo e o átomo cujo contexto compreende o novo objetivo.
} 
que haja alguma semântica embutida na designação do objetivo, ela não se sustentará durante o processo de construção do grafo. Isto porque para o esquema, o objetivo em si é apenas um conjunto de sensações a serem alcançadas, um pretexto para organizar as relações sensório-motoras que podem levar à sua obtenção. Nestas condições se pode pensar, inclusive, em objetivos gerados de forma aleatória.

\subsubsection{Sobre o modelo de esquema}

O principal ganho do sistema com o uso do esquema proposto é o da ampliação espaço-temporal das predições sensório-motoras realizadas por um único átomo de causalidade. O grafo sensório-motor que representa o esquema permite ao sistema apreender relações causais não-lineares armazenadas em seus nós e nas associações entre eles.

A ampliação espacial apreendida pelo esquema pode ser vista pelo contexto sensório ao qual ele se aplica. Contexto este formado pela união dos contextos sensórios dos átomos de causalidade que compõem o grafo do esquema. A ampliação temporal pode ser percebida pelos caminhos formados pelos encadeamentos dos átomos do grafo.

Apesar de ampliar o alcance espaço-temporal, o esquema possui algumas limitações. As limitações do modelo proposto ocorrem principalmente pelo fato do esquema não perceber todas as variáveis do ambiente no qual está inserido. Lembremos que não é exigido que os sensores e atuadores do esquema estejam conectados a todos os sensores e atuadores do agente. Também, não é exigido que os sensores do agente sejam capaz de captar todos os possíveis estados do ambiente no qual o agente está inserido. Assim, mesmo que o ambiente seja regrado por relações determinísticas, o fato do esquema perceber apenas um subconjunto dos possíveis estados faz com que o mundo se apresente para ele como sendo não-determinístico.

O não-determinismo experienciado pelo esquema se reflete na construção do grafo, impedindo que alguns átomos atinjam o estado treinado. Isto porque os átomos são 
incapazes de apreender relações não-determinísticas. Como o grafo cresce pela adição de átomos associados aos átomos que passam para o estado treinado (Seção 3.2.2), o grafo tem seu crescimento podado. Assim, as fronteiras entre as relações determinísticas e as não-determinísticas são refletidas nas fronteiras de crescimento do grafo.

A apreensão das relações não-determinísticas resultantes do fato dos sensores e atuadores do esquema não se corresponderem a todos os sensores e atuadores do agente é tratada pelo mecanismo de coordenação dos esquemas, apresentado na Seção 3.3. Já a apreensão das relações não-determinísticas advindas do fato do agente não ser capaz de perceber simultaneamente todo o ambiente (visão parcial) é o foco principal deste trabalho e é tratado pelo desenvolvimento da noção de objeto. Note que nos modelos de esquemas estudados, este segundo tipo de apreensão é tratado pela utilização do conceito de item sintético.

\subsection{Coordenação entre esquemas}

A unidade do modelo de esquema proposto (grafo sensório-motor) é o átomo de causalidade. Os átomos são agrupados em rede para formar os esquemas. Estes representam as unidades cognitivas básicas na composição do sistema cognitivo de agentes computacionais. Nesta seção veremos como os esquemas são coordenados para formarem uma rede que representa o primeiro nível da hierarquia de esquemas.

Antes de vermos como se dá a coordenação entre os esquemas, vamos situar o problema a que a coordenação se presta utilizando como exemplo um modelo simplificado e ilustrativo do desenvolvimento da coordenação entre a visão e a preensão.

Como exemplo usaremos um agente que possui um esquema responsável pelo controle da mão ${ }^{6}\left(E^{M}\right)$ e outro responsável pelo controle da visão $\left(E^{V}\right)$. O esquema $E^{M}$ possui como sensores o posicionamento e as sensações táteis da mão, e como atuadores

\footnotetext{
${ }^{6}$ Apesar de usarmos o termo mão, deve-se pensar na composição braço, ante-braço e mão.
} 
a movimentação dos músculos da mão. $\mathrm{O}$ esquema $E^{V}$ possui como sensores o campo visual e o posicionamento dos olhos e cabeça, e como atuadores a movimentação dos olhos e da cabeça. Note que no exemplo não há sensores ou atuadores comuns aos dois esquemas. Também, consideraremos que ambos os esquemas já foram treinados. Ou seja, o esquema $E^{M}$ já sabe como pegar um objeto a partir do momento em que a mão o toca. Da mesma forma, $E^{V}$ já sabe como focar nos objetos que estejam dentro do campo de visão.

O problema da coordenação visão-preensão é o de encontrar as relações causais que permitam ao sistema ver o que está segurando (mesmo que o objeto ainda esteja fora do campo visual) e segurar o que está vendo (mesmo que a mão ainda não esteja tocando o objeto). Nitidamente, há a utilização do domínio sensório utilizado por um esquema para a ativação do outro esquemas. Pretende-se averiguar como estas utilizações cruzadas entre os domínios de esquemas distintos podem computacionalmente ser alcançadas e se, efetivamente, o mecanismo proposto é suficiente para embutir no agente as conquistas relativas à coordenação dos esquemas.

Com relação à noção de objeto, a coordenação dos esquemas deverá fornecer a capacidade de caracterização dos objetos, dando-lhes uma identidade única. O objeto é definido, também, pelos seus vários aspectos particulares como: cor, peso, barulho que faz ao ser jogado ou batido, forma, etc. A reunião destes aspectos em ações únicas deve ser possível com a coordenação de esquemas.

\subsection{Hierarquia de esquemas}

A hierarquização dos esquemas se dá pela criação de camadas superiores de esquemas conectadas às camadas inferiores por seus sensores e atuadores. Um esquema de nível superior percebe os estados (ex: excitação, ativação) dos esquemas inferiores por seus sensores e influencia seus comportamentos (ex: ativação) pela modificação 
dos seus atuadores.

A hierarquização, segundo Piaget, é a fonte do aumento da abstração dos conceitos. Por exemplo: ao invés de preocupar-se com os detalhes sensório-motores necessários para apanhar um objeto (esquema primário), o esquema secundário pode preocupar-se com o que fazer assumindo que já se sabe como pegar o objeto. As distintas formas de como se pode pegar os objetos pressupõem planejamentos sensóriomotores distintos que não interessam ao esquema secudário. Este pode, então, ater-se apenas à representação do conceito mais genérico de pegar objetos. Da mesma forma, a hierarquização de esquemas permite, também, a criação de categorias, porém ainda em um mundo restrito à forma sensório-motora de organização cognitiva..

\subsection{Esquemas móveis}

Piaget usa o conceito de esquemas móveis para designar esquemas que podem ser aplicados não somente a outros esquemas, mas a configurações de esquemas. Os esquemas móveis são evoluções das estruturas hierárquicas rígidas e permitem a recombinação dinâmica de seus conteúdos. Os esquemas secundários destacam-se do seu conteúdo habitual para se aplicarem a um número crescente de objetos: de esquemas particulares com um conteúdo específico ou singular, tornam-se esquemas genéricos com um conteúdo múltiplo. Segundo Piaget, “... a coordenação dos esquemas secundários e, consequentemente, as suas dissociações e reagrupamentos dão origem a um sistema de esquema móveis cujo funcionamento é muito comparável ao dos conceitos ou dos juízos característicos da inteligência verbal ou reflectidora.” (PIAGET, 1936, pg 253).

Os esquemas móveis, em relação à noção de objeto, representam a separação final entre a simples percepção dos sinais sensórios e a consolidação de entidades espaçotemporalmente constantes extraídos da semântica por trás dos sinais sensoriais. 
Na prática, a criação dos esquemas móveis será estudada a partir dos padrões de organização dos esquemas e seus átomos de causalidade que deverão surgir conforme estes são treinados com as atividades do agente. Para um exemplo, imagine que o agente pegue o objeto $A$ e o leve até a frente de sua visão. Agora imagine que o agente pegue o objeto $B$ e também o leve à frente de sua visão. Com a repetição destes exercícios, tem-se que alguns esquemas serão utilizados por ambos os processos, pois são comuns. Porém, outros esquemas serão bastante distintos, como os de reconhecimento do objeto $A$ e os de reconhecimento do objeto $B$. Assim também, serão distintos os esquemas para segurar os dois objetos. Porém, a organização destes esquemas possuirá características comuns. Estas formas de organização podem ser utilizadas para treinar esquemas móveis que futuramente podem ser aplicados a ambas as situações. 


\section{IMPLEMENTAÇÃO COMPUTACIONAL}

A implementação computacional do modelo proposto quando pensada sob o paradigma do DCAA chama a atenção para o fato de que o modelo teórico define as estruturas do sistema, suas relações e as dinâmicas resultantes, porém os conceitos utilizados não são suficientes para expressar a natureza computacional do desenvolvimento autônomo a ser trilhado pelo sistema para alcançar a concepção que o modelo representa. Dito de outra forma, os conceitos utilizados pelo modelo teórico não esgotam os conceitos necessários para a adequação de sua implementação computacional quando pensada sob o paradigma do DCAA. Tendo esta questão em mente, este capítulo foi organizado de forma a refletir sobre os principais conceitos de implementação abrindo mão da organização textual utilizada na exposição do modelo teórico.

A Seção 4.1 trata de situar o leitor quanto à transposição dos principais conceitos do modelo teórico para os conceitos utilizados para expressar a implementação computacional.

A Seção 4.2 apresenta a base computacional sobre a qual o átomo de causalidade se assenta: um classificador implementado por redes neurais artificiais alinhado com o paradigma do DCAA. A Seção 4.3 apresenta um mecanismo que estende o classificador para a decomposição da classe em subconjuntos convexos, implementando o procedimento de divisão descrito na Seção 3.2.5. Por último, a Seção 4.4 apresenta como a rede neural classificatória se organiza em um grafo sensório-motor que alinhase com o modelo teórico de esquema proposto. 


\subsection{Adequação do modelo ao DCAA}

No modelo proposto, o átomo de causalidade representa a relação sensório-motora causal associada ao menor intervalo de tempo que o sistema pode perceber. O esquema é o grafo resultante da organização de vários átomos.

A associação causal representada pelos átomos é adquirida pela classificação das situações sensório-motoras que, deterministicamente, levam às situações seguintes. Assim, o mecanismo computacional básico para a construção da identidade de cada átomo é o classificador a ele associado, conjuntamente com os exemplos de classe e não-classe utilizados para treiná-lo. A autonomia do desenvolvimento de cada átomo está, portanto, associada à não contaminação do classificador pelos conceitos do seu projetista, seja tanto pela definição de sua estrutura ou forma de operação, quanto das pressuposições acerca da natureza dos exemplos utilizados.

O processo de divisão, base para a transformação da estrutura do esquema de lista para árvore computacional, apesar de no modelo teórico estar intimamente relacionado ao contexto do esquema, relaciona-se diretamente à classe delineada pelo classificador. O pensamento de que o classificador pode fornecer subconjuntos da classe de seu interesse (divisão) que possam ser aproveitados, ou mesmo que estimulem os átomos a se reorganizarem compondo grafos permite pensar os átomos e o esquema como sendo decorrentes das dinâmicas dos classificadores, pensamento este que será desenvolvido na Seção 4.3.

Também, o pensar que a identidade de um esquema se dá principalmente pelo compartilhamento do espaço sensório-motor pelos átomos que o constitui, ressalta a importância das não-classes que definem o complemento do espaço sensório-motor e que será alvo para os novos classificadores. Ou seja, o complemento da classe definida por um classificador (sua não-classe) diz sobre a definição das classes dos outros classificadores que também compõem o esquema, pois estas são mutuamente excludentes. 
Aqui também se vê o esquema e os átomos sendo estimulados pela constituição da classe de cada classificador. Este aspecto ficará mais claro na Seção 4.4, quando da explanação do grafo sensório-motor que representa o esquema.

\subsection{Classificador para sistemas baseados em DCAA}

A estrutura computacional básica do modelo de esquema proposto é o átomo de causalidade cuja estrutura é dada principalmente por um classificador incumbido de encontrar a classe que representa o domínio sensório-motor do átomo. Porém, apesar de ter seu papel bem definido, outras características do mecanismo computacional que constitui o classificador são importantes ao pensá-lo como um componente que estará contribuindo para a formação de um sistema mais amplo regido pelo paradigma do DCAA.

Nesta seção nos ateremos apenas ao modelo computacional do classificador utilizado. Suas relações com o modelo teórico do átomo de causalidade e do esquema serão estabelecidas quando da exposição da implementação computacional destas estruturas mais amplas que o abarcam.

A principal característica do classificador sob o DCAA é a de que ele será criado, ajustado e utilizado por um sistema computacional constrastando com classificadores utilizados em outras aplicações onde um projetista humano pode se responsabilizar pela criação, ajuste e determinação do contexto no qual o classificador será utilizado. Ainda, assumindo que o processo de classificação é um dos componentes básicos para a constituição de processos cognitivos, deve-se assumir que o sistema computacional do qual o classificador participará pode ainda não ser complexo o suficiente para desempenhar papéis que se aproximem dos de um projetista humano. Consequentemente, o classificador deve ter o máximo de autonomia na constituição de sua própria estrutura e, também, o máximo de independência nas pressuposições sobre as carac- 
terísticas do seu entorno. Durante a pesquisa foram notados os três seguintes pontos acerca do entorno no qual o classificador sob este contexto pode estar inserido:

1. Cardinalidade do conjunto de amostras: as amostras da classe são percebidas como um stream de dados e não como conjuntos previamente conhecidos. Tal pressuposição é conhecida como amostragem ou treinamento online.

2. Representabilidade das amostras: em nenhum momento há como assumir que as amostras já percebidas bastam para representar toda a classe alvo.

3. Determinação autônoma dos parâmetros estruturais: a estrutura e os parâmetros que regem os processos do classificador não têm como depender de critérios externos ao seu funcionamento, como por exemplo, ajustes realizados em decorrência de observações do projetista.

A busca por um modelo computacional de classificador que estivesse condizente com os pontos percebidos resultou no desenvolvimento de um novo modelo de classificador. As motivações para tal desenvolvimento, com base nos pontos observados, assim como o modelo computacional resultante são expostos ao longo desta seção.

\subsubsection{Motivação}

O paradigma de Redes Neurais Artificiais (RNA) tem sido amplamente utilizado para a implementação de classificadores genéricos. Em particular, RNAs com arquitetura Feed-Forward utilizando apenas uma camada oculta (RNAFF-1) são provadas serem classificadores universais (KURKOVA, 1992). Porém, um dos problemas ao se utilizar RNAFF-1s como classificadores é o estabelecimento do número de elementos de sua camada oculta, pois este é fortemente dependente da classe que se quer encontrar e que, obviamente, não é conhecida de antemão.

Se por um lado o número de elementos da camada oculta deve ser suficiente para representar as particularidades da classe alvo, por outro, se um número demasiado de 
elementos for utilizado a capacidade de generalização do classificador é comprometida fazendo com que a classe resultante se restrinja a pontos próximos às amostras utilizadas, fenômeno este conhecido como over-fitting.

Quando o sistema computacional é pensado estritamente para realizar a tarefa de encontrar uma classe que generalize um conjunto preestabelecido de amostras, o projetista humano pode garantir que as amostras representem a classe buscada (conjuntos de treinamento e teste) e também pode averiguar o desempenho do classificador em um conjunto separado de amostras para validação. Neste processo, o projetista pode testar classificadores com camada oculta de diversos tamanhos ${ }^{1}$. Por outro lado, classificadores pensados para serem utilizados como ferramentas computacionais básicas para a constituição de sistemas computacionais mais amplos não devem depender de critérios externos para o estabelecimento do número de elementos de sua camada oculta.

Duas estratégias são utilizadas para a determinação dinâmica do número de elementos da camada oculta de classificadores RNAFF-1.

- Abordagem incremental. Nesta estratégia a camada oculta da rede é iniciada com poucos elementos. Novos elementos são adicionados até que seu desempenho seja tido como satisfatório. Como regra geral, o critério utilizado para criar um novo elemento, assim como o critério utilizado para definir a estrutura final da rede são baseados na performance do classificador em relação a um conjunto predefinido de amostras, o conjunto de teste. (FAHLMAN; LEBIERE, 1990), (FAHLMAN, 1990) e (LITTMANN; RITTER, 1992).

- Abordagem por poda. Nesta outra estratégia a rede é iniciada com um número superestimado de elementos na camada oculta. Apenas os elementos que se mostrem importantes no delineamento da classe são mantidos na rede.

Neste trabalho seguiremos a abordagem por poda. Segundo (REED, 1993) podemos

\footnotetext{
${ }^{1}$ Note que, mesmo que este processo seja automatizado ele continua exigindo a existência de conjuntos pré-definidos de amostras.
} 
pensar os algoritmos de poda sob três categorias conforme o critério utilizado para a redução do número de variáveis utilizadas pela RNA:

- Força bruta. Um ou mais elementos são retirados da camada oculta. Se o desempenho do classificador resultante for menor do que o da rede anterior os elementos são reinseridos, caso contrário a nova rede é mantida. O processo continua até que nenhum elemento possa ser removido sem diminuir o desempenho do classificador.

- Calculo da sensibilidade. A importância de cada elemento para a constituição da classe é estimada segundo alguma métrica. Elementos com importância abaixo de um certo limite são removidos. Os algoritmos nesta categoria variam principalmente na métrica utilizada para medir a importância dos elementos.

- Termo de penalização. Uma função de custo que depende dos parâmetros da rede a serem ajustados (pesos e biases) é adicionada à função de erro do classificador. Ao buscar minimizar o erro, o algoritmo de treinamento estará minimizando não só a desconformidade à classe mas também o custo da existência de cada parâmetro.

A abordagem de poda com termo de penalização para a determinação dinâmica e autônoma do número de elementos da camada oculta, por suas características, parece estar mais próxima aos três pontos notados acerca do entorno no qual o classificador pode estar inserido quando em conformidade com o DCAA. A seguir nos aprofundaremos um pouco mais nestes quesitos.

\subsubsection{Cardinalidade do conjunto de amostras}

A pressuposição de que o classificador deve ser construído estritamente com base em amostras da classe percebidas como um stream de dados limita os algoritmos que podem ser utilizados para reger as atividades do classificador. Isto porque não há um 
conjunto de amostras que possa ser utilizado para medir qualquer tipo de performance ou critério absoluto ou esperado. Como consequência, há duas fortes limitações que se impõem a estes algoritmos.

- A falta de medida absoluta da performance. Não há como depender de alguma métrica que estabeleça o quão distante o estado atual dos parâmetros do classificador está da solução final esperada; Uma das consequências desta limitação é a de que as fases de treinamento, teste e validação normalmente utilizadas não têm como serem distinguidas e, portanto, devem ser repensadas como partes de um único processo.

- A falta de medidas absolutas sobre a importância de um peso da rede. Medidas absolutas da importância de cada peso da rede são normalmente utilizadas por algoritmos de poda. As importâncias dos pesos são determinadas pela análise do conjunto de amostras. A dificuldade de estabelecer tais importâncias quando não se tem de antemão as amostras, aponta para uma abordagem distribuída competitiva. Nesta, os pesos da rede competem entre si por suas contribuições às regiões no domínio da classe, evitando a necessidade de estabelecer de antemção as importâncias dos pesos.

\subsubsection{Representabilidade das amostras}

As amostras de classe apresentadas ao classificador pelo agente dependem da situação na qual o agente se encontra no ambiente. Mesmo sendo o agente capaz de informar se a amostra atual fornecida ao classificador pertence ou não à sua classe alvo, ele é incapaz de garantir que as amostras já apresentadas possam constituir uma amostragem significativa do domínio da classe. Em outras palavras, o critério sobre a representabilidade do domínio da classe é externo ao próprio sistema e ao agente. Note que nos casos onde o classificador é treinado a partir de um conjunto predefinido de amostras, o projetista é o responsável por assegurar que as amostras utilizadas para o 
treinamento são capazes de representar a classe buscada.

Enquanto o agente permanecer em uma certa região do ambiente as amostras que chegarão ao classificador estão restritas às situações propiciadas por aquela região. Quando o agente muda para outra região as amostras que chegam ao classificador podem mapear uma outra região do domínio da classe que até então não havia sido explorada. Quanto tempo o agente ficará em uma região e quantas outras regiões ainda não foram visitadas e que refletem na amostragem para o classificador, e também quando estas novas regiões serão visitadas, o próprio agente não tem como saber, visto que ainda estamos considerando um sistema cognitivo simples. Consequentemente não há como o algoritmo de constituição do classificador, em nenhum momento, considerar que as amostras até então apresentadas são capazes de representar o domínio da classe de interesse.

Como consequência direta desta característica da amostragem, dentro do paradigma do DCAA o algoritmo do classificador deve ser capaz de manter as características das amostras já processadas, mas flexível o suficiente para incorporar características de novas regiões de seu domínio. Note que esta flexibilidade do classificador é desejável mesmo assumindo que o agente esteja inserido em ambientes determinísticos e que também não exclui a existência de ruídos nas amostras.

\subsubsection{Determinação autônoma dos parâmetros estruturais}

A terceira questão acerca do algoritmo utilizado por classificadores sob o DCAA se refere à capacidade de estabelecer seus próprios parâmetros.

Alguns parâmetros utilizados pelos algoritmos de classificação podem ser constantes durante toda a execução e, mais ainda, ter o mesmo valor para uma ampla gama de problemas (classes). Por outro lado, pode haver parâmetros cujos valores não podem ser os mesmos para a resolução de problemas distintos, ou ainda parâmetros que devem variar ao longo da execução do algoritmo na resolução do mesmo problema. 
Os parâmetros que não podem ser prefixados são considerados dinâmicos. Para os parâmetros dinâmicos, o algoritmo deve apresentar alguma forma de auto-regulação que permita atualizar seus valores de forma a não comprometer sua capacidade em encontrar a classe buscada.

Em classificadores sob o DCAA, o problema da representabilidade das amostras reflete em como o comportamento dos parâmetros dinâmicos é concebido. Como um exemplo, o tamanho do passo utilizado por algoritmos de treinamento com base no método de gradiente descendente pode ser tratado como um parâmetro dinâmico sendo decrementado a cada iteração. Esta abordagem faz com que no início o classificador se aproxime rapidamente a uma possível solução e que depois, com passos menores, refine sua aproximação à solução encontrada até estagnar em um ponto (minPasso = 0) ou ter sua mobilidade restrita (minPasso $>0$ ). Perceba que apesar do tamanho do passo ser controlado pelo próprio algoritmo, o classificador não será capaz de lidar com novas regiões do domínio da classe, se acaso estas se apresentarem.

\subsubsection{Algoritmos de poda}

Dentre as diferentes abordagens pesquisadas sobre as formas de estabelecimento dinâmico do número de elementos da camada oculta a abordagem de poda utilizando termos de penalização se destaca como sendo a mais próxima ao paradigma do DCAA. Isto porque, no modelo de poda a camada oculta pode ser iniciada com um número sobre-estimado de elementos que competirão entre si para representar regiões distintas do domínio do classificador. Ao mesmo tempo, a utilização de termos de penalização pode ser concebida de forma a incentivar a manutenção dos elementos que primeiro se estabeleçam em regiões ainda não mapeadas, liberando os demais elementos para buscarem a estabilidade em outras regiões. 


\subsubsection{Modelo computacional}

O desafio enfrentado pelo modelo computacional de um classificador baseado em RNAFF-1 e que esteja alinhado com o paradigma do DCAA não se restringe à utilização de um algoritmo capaz de encontrar um número adequado de elementos para a camada oculta. A dificuldade para com a conformidade ao DCAA está principalmente na limitação dos recursos utilizados pelo algoritmo e das pressuposições acerca dos contextos nos quais estará inserido.

\subsubsection{Estrutura}

A estrutura computacional do classificador proposto é dada por uma rede neural artificial feed-forward com uma única camada oculta (RNAFF-1). Por motivos didáticos utilizaremos um classificador com apenas uma saída notando que a generalização para mais de uma saída (classe) pode ser facilmente realizada. A Figura 8 mostra a estrutura da rede utilizada.

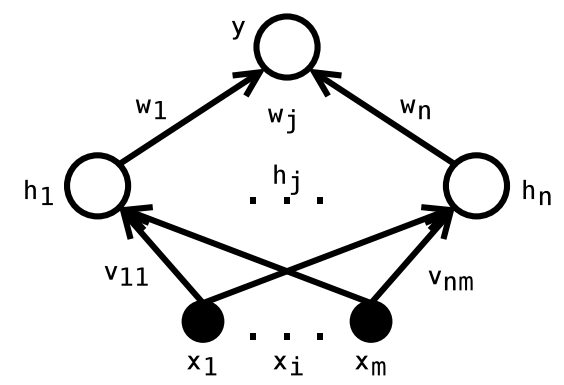

Figura 8: Rede neural feed-forward com uma única camada oculta que implementa o classificador.

Seja o domínio de entrada dado por $D \subseteq[1,+1]^{m} \subset \mathbb{R}^{m}$, as amostras da classe são dadas por $\left[\mathbf{x}_{\mathbf{t}}, e_{t}\right]$, onde $e_{t} \in\{1,+1\}$ representa a classificação esperada para a entrada $\mathbf{x}_{t} \in D$ no tempo $t=1,2, \ldots$. A saída do classificador $y(\mathbf{x})$ é calculada por:

$$
\begin{aligned}
& y(\mathbf{x})=f\left(b+\mathbf{w}^{T} \mathbf{h}(\mathbf{x})\right) ; \\
& h_{j}(\mathbf{x})=f\left(a_{j}+\mathbf{V}_{\mathbf{j}}{ }^{T} \mathbf{x}\right) ; \quad j=1, . ., n
\end{aligned}
$$


onde:

- $y: \mathbb{R}^{m} \mapsto(1,+1) \subset \mathbb{R}$ : saída do classificador;

- $f: \mathbb{R} \mapsto(1,+1)$ : função de ativação dos elementos da rede, $f()=.\tanh ($.$) ;$

- $b \in \mathbb{R}:$ bias da saída.

- $\mathbf{w} \in \mathbb{R}^{n}:$ pesos das conexões entre a camada oculta e a saída;

- $\mathbf{h}: \mathbb{R}^{m} \mapsto(1,+1)^{n}$ : saídas da camada oculta;

- $\mathbf{a} \in \mathbb{R}^{n}$ : bias da camada oculta;

- $V \in \mathbb{R}^{m \times n}:$ pesos das conexões entre a camada de entrada e a oculta sendo que os vetores coluna $\mathbf{V}_{\mathbf{j}} \in \mathbf{R}^{m}$ representam os pesos das conexões da entrada ao j-ésimo elemento da camada oculta;

- $\mathbf{x} \in D$ : entradas do classificador.

\subsubsection{Dinâmica das iterações}

A estrutura da rede é iniciada com um grande número de elementos na camada oculta, $M$. As variáveis da rede, seus pesos $(V, \mathbf{w})$ e seus biases $(\mathbf{a}, b)$ são iniciados aleatoriamente.

Como aqui nos interessa o algoritmo utilizado para encontrar o número de elementos da camada oculta e não o algoritmo de treinamento do classificador, a atualização das variáveis da rede será dividida em dois momentos: treinamento e poda. Para isto representaremos o estado das variáveis no instante de tempo $t$ por $U(t)=$ $[V(t), w(t), a(t), b(t)] \in \mathbb{R}^{P}$, onde $P=n \cdot m+2 n+1$. Também, representaremos os estados destas variáveis após o treinamento por $\bar{U}(t) \in \mathbb{R}^{P}$, dado por:

$$
\bar{U}(t)=[\bar{V}(t), \overline{\mathbf{w}}(t), \overline{\mathbf{a}}(t), \bar{b}(t)]=T\left(U(t), \mathbf{x}_{t}, e_{t}\right)
$$


onde $T: \mathbb{R}^{P} \mapsto \mathbb{R}^{P}$ representa a aplicação do algoritmo de treinamento. Note que $\bar{V}(t), \overline{\mathbf{w}}(t), \overline{\mathbf{a}}(t)$ e $\bar{b}(t)$ referem-se aos estados das respectivas variáveis, após o treinamento. É importante frisar que por sua simplicidade, o algoritmo backpropagation com gradiente descendente utilizando um valor constante para o passo de atualização será adotado como o algoritmo de treinamento $T$ durante este trabalho.

Em resumo, a cada iteração os estados das variáveis $U(t)$ são utilizados pelo algoritmo de treinamento $T$ para encontrar os estados treinados $\bar{U}(t)$. Em seguida, ainda na mesma iteração, o algoritmo de poda é aplicado a $\bar{U}(t)$ para encontrar os estados no próximo instante $U(t+1)$, o que será visto na próxima seção. É importante notar que o procedimento de iteração nunca cessa, mesmo após o classificador estar condizente com seus objetivos. Esta característica permite que, apesar de se conformar às amostras correntes da classe, o classificador possa se readaptar a novas situações.

\subsubsection{Otimização da estrutura}

Nesta seção veremos como os estados das variáveis da rede após o treinamento $\bar{U}(t)$ são utilizados pelo algoritmo de poda para encontrar os próximos estados $U(t+1)$.

Seguindo o modelo de poda por termos-de-penalização, uma função de custo é associada a cada componente de $\bar{U}(t)=[\bar{V}(t), \overline{\mathbf{w}}(t), \overline{\mathbf{a}}(t), \bar{b}(t)]$. O algoritmo de poda modifica os valores destas variáveis buscando minimizar a soma de seus custos, atualizandoos na direção do gradiente descendente. A função que expressa o valor desta atualização será chamada de função de penalização. Assim, a penalização é tida como proporcional ao gradiente da função de custo. No modelo proposto, nenhum custo é associado aos biases da rede: $\overline{\mathbf{a}}(t)$ e $\bar{b}(t)$. Apenas os pesos $V$ e w têm custos associados.

Sendo a função de penalização dos pesos $V$ dada por $p_{v}: \mathbb{R}^{N \times M} \mapsto \mathbb{R}^{N \times M}$ e a função de penalização dos pesos $\mathbf{w}$ dada por $p_{w}: \mathbb{R}^{M} \mapsto \mathbb{R}^{M}$, o valor das variáveis da 
rede no próximo instante de tempo $U(t+1)$ é calculado por:

$$
\begin{aligned}
U(t+1) & =[V(t+1), \mathbf{w}(t+1), \overline{\mathbf{a}}(t), \bar{b}(t)] \\
V(t+1) & =\bar{V}(t)+p_{v}(\bar{V}(t)) \\
\mathbf{w}(t+1) & =\overline{\mathbf{w}}(t)+p_{w}(\overline{\mathbf{w}}(t))
\end{aligned}
$$

Atualização dos pesos da camada de entrada. A função de penalização $p_{v}$ aplicada a $\bar{V}$ é gerada a partir da função de custo $c_{v}: \mathbb{R}^{m \times n} \mapsto \mathbb{R}$ proposta por Chauvin (CHAUVIN, 1989):

$$
\begin{aligned}
& c_{v}(\bar{V})=\sum_{i}^{n} \sum_{j}^{m} \bar{V}_{i j}^{2} ; \\
& p_{v}(\bar{V})=\frac{v}{2} \nabla c_{v}(\bar{V})={ }_{v} \bar{V} ;
\end{aligned}
$$

onde ${ }_{v} \in[0,1) \subset \mathbb{R}$ é o coeficiente de penalização dos pesos $V$. Note que $p_{v}$ é construída para minimizar o custo indicado por $c_{v}$ e que por (4.3) e (4.6) a atualização de $V$ pelo algoritmo de poda é dada por:

$$
V(t+1)=(1 \quad v) \bar{V}(t)
$$

Atualização dos pesos da camada oculta. Assim como ocorre com a função de penalização $p_{v}$, a função de penalização $p_{w}$ aplicada aos pesos $\mathbf{w}$ tem o intuito de minimizar o custo a eles associado, dado pela função $c_{w}: \mathbb{R}^{n} \mapsto \mathbb{R}$ definida como:

$$
\begin{aligned}
c_{w}(\bar{w}) & =\sum_{j}^{n} \bar{c}_{w}\left(\bar{w}_{j}\right) \\
\bar{c}_{w}\left(\bar{w}_{j}\right) & \left.\left.=\frac{w}{2 \pi} \quad 1 \quad \cos \frac{2 \pi \bar{w}_{j}}{\tau}\right)\right)
\end{aligned}
$$

onde:

- $\bar{c}_{w}: \mathbb{R} \mapsto \mathbb{R}$ : função de custo associada a cada peso $w_{j}$;

- $0 \leq{ }_{w} \in \mathbb{R}$ : amplitude do fator de penalização; 
- $0<\tau \in \mathbb{R}$ : período do fator de penalização.

É importante ressaltar que a utilização de (4.8) para o cálculo do custo dos pesos de saída da rede é fruto das pesquisas realizadas durante o desenvolvimento desta tese.

A função de penalização $p_{w}$ é dada por:

$$
p_{w}(\bar{w})=\nabla c_{w}(\bar{w})
$$

Assim, por (4.4), (4.8) e (4.10) a atualização dos pesos da saída w contando com a influência do algoritmo de poda é dada por:

$$
\left.w_{j}(t+1)=\bar{w}_{j}(t) \quad \frac{w}{\tau} \sin \frac{2 \pi \bar{w}_{j}(t)}{\tau}\right) ; \quad j=1, . ., n .
$$

Comportamento dos pesos da camada oculta. Um ponto importante a ser ressaltado em relação ao comportamento gerado pela aplicação do algoritmo de poda diz respeito aos pontos de atração introduzidos pelas funções de custo associadas aos pesos da rede.

Note que a função de custo $c_{v}$ definida em (4.5) utilizada para $V$ introduz um único atrator localizado na origem (zero) fazendo com que o algoritmo de poda tenha o efeito de minimizar o módulo dos pesos de $V$, ao mesmo tempo em que o algoritmo de treinamento ajusta seus valores para solucionar o problema de classificação.

Já o efeito do algoritmo de poda sobre os pesos $\mathbf{w}$ ao utilizar a função de custo $c_{w}$ definida em (4.8) é um pouco mais complexo. Isto porque $c_{w}$ introduz infinitos pontos de atração, $a_{k} \in \mathbb{R}$, incluindo a origem (zero). Cada atrator gera uma bacia de atração $B_{k}$. Tem-se então:

$$
\begin{aligned}
& a_{k}=k \tau ; \\
& B_{k}=\left\{x \in \mathbb{R} \mid \tau\left(\begin{array}{ll}
k & 1 / 2)<x<\tau(k+1 / 2)\} . \quad \forall k \in \mathbb{Z}
\end{array}\right.\right.
\end{aligned}
$$

Como consequência, se $w_{j} \in B_{k}$ então a penalização (4.11) adiciona uma força que 
direciona $w_{j}$ para $a_{k}$. Note que os atratores $a_{k}$ são controlados pelo período da penalização $\tau$ e que a amplitude da penalização ${ }_{w}$ controla a intensidade da atração aplicada.

Na iniciação da rede os pesos da camada oculta são iniciados com valores aleatórios, porém todos com valores absolutos menores do que $\tau / 4$ de forma que pertençam à bacia $B_{0}$. A cada instante o algoritmo de treinamento aumenta o módulo destes pesos conforme a importância que tenham na adequação da rede à classe buscada. Então o algoritmo de penalização é aplicado levando cada peso $w_{j}$ em direção ao atrator associado à bacia na qual está inserido. Como todos os pesos são iniciado na bacia $B_{0}$ apenas os pesos com uma certa relevância serão capazes de transpor $B_{0}$ e alcançar uma de suas bacias vizinhas $B_{1}$ ou $B_{+1}$ passando a ser atraído, ou empurrado, em direção ao seu novo atrator $a_{1}$ ou $a_{+1}$, respectivamente.

Para ilustrar o comportamento dos pesos w, digamos que os elementos da camada oculta $h_{r}$ e $h_{s}$ estejam mapeando regiões sobrepostas do domínio da classe, sendo $w_{r}$ e $w_{s}$ os pesos que os conectam à saída, respectivamente. Agora imagine que $w_{r}$ ainda se encontra na bacia $B_{0}\left(\tau / 2<w_{r}<+\tau / 2\right)$ enquanto $w_{s}$ acaba de alcançar a bacia $B_{+1}$ $\left(+\tau / 2<w_{s}<\tau\right)$. Note que, como $w_{s}$ acaba de alcançar $B_{+1}$ ainda não houve tempo para chegar ao atrator $a_{+1}=\tau$. Nesta situação, o algoritmo de poda modifica $w_{r}$ em direção a $a_{0}=0$ diminuindo sua magnitude $\left|w_{r}\right|$. Ao mesmo tempo $w_{s}$ é modificado em direção ao seu novo atrator $a_{+1}=\tau$ aumentando sua magnitude $\left|w_{s}\right|$. Assim, quando $h_{r}$ e $w_{s}$ estiverem competindo pela mesma região segundo o algoritmo de treinamento, o algoritmo de poda previlegiará $h_{s}$ em detrimento de $h_{r}$. Como consequência, o algoritmo de poda atua no sentido de evitar competições dos elementos da camada oculta pelas mesmas regiões do domínio da classe permitindo que os elementos se dirijam a regiões ainda não mapeadas ou não mais participem $\left(\left|w_{j}\right| \rightarrow 0\right)$ quando toda a classe tiver sido mapeada. 
Poda dos elementos da camada oculta. Ao longo do tempo os pesos w sob a influência do algoritmo de poda tendem a se estabilizar em algum atrator $a_{k}$ da função de custo $c_{w}$. Seguindo o paradigma do DCAA, os processos de treinamento, classificação e poda ocorrem simultaneamente e em todas iterações. Da mesma forma que toda amostra gera uma saída que indica a opinião do classificador em relação à sua pertinência à classe (classificação), toda amostra também é utilizada para treinar o classificador (treinamento). Também, a poda é tida como um processo contínuo.

Em última instância, o procedimento de poda aplicado à camada oculta se resume a identificar os elementos que pouco ou nada contribuem à constituição da classe e que, portanto, podem ser removidos da estrutura da rede. No modelo proposto um elemento é considerado supérfluo quando o peso $w_{j}$ a ele associado se encontra na bacia $B_{0}$.

\subsubsection{Sobre a autonomia dos parâmetros}

No modelo computacional proposto para o desempenho da função de classificação necessária ao átomo de causalidade, apesar de deixar em aberto o algoritmo de treinamento do classificador, foi assumido que sua estrutura é dada por uma RNAFF com apenas uma camada oculta. Apenas com base nesta estrutura, um algoritmo de poda foi proposto para que o estabelecimento do número de elementos da camada oculta da rede pudesse ser encontrado de forma autônoma alinhando o classificador ao paradigma do DCAA. Porém, pode-se notar que o algoritmo de poda proposto se utiliza de três parâmetros: o coeficiente de penalização ${ }_{v}$ utilizado pela função de custo $c_{v}$, o período $\tau$ e a amplitude ${ }_{w}$ do fator de penalização utilizados pelo custo $c_{w}$.

À primeira vista estamos trocando a incumbência de designar o parâmetro que determina o número de elementos da camada oculta pela de designar os parâmetros ${ }_{v}, \tau$ e ${ }_{w}$. No entanto, diferentemente do número de elementos da camada oculta, a determinação destes novos parâmetros se encaixa sob o paradigma do DCAA.

Experimentos internos mostraram que o parâmetro ${ }_{v}$, em acordo com o proposto 
por Chauvin (CHAUVIN, 1989), pode ser tido como constante. Neste trabalho, valores da ordem de grandeza de $10{ }^{5}$ foram utilizados. Assim como ${ }_{v}$, o parâmetro $\tau$ que determina o período da função de custo $c_{w}$ e, consequentemente os atratores dos pesos w pôde ser fixado em valores no intervalo $[0.5,2.0]$ para grande parte dos problemas testados. O valor utilizado para $\tau$, no geral, não compromete a capacidade do classificador em alcançar estruturas satisfatórias, mas influencia no número de iterações necessárias para tal.

Diferentemente de ${ }_{v}$ e $\tau$, para que o classifidor alcance estruturas satisfatórias, o valor do parâmetro $\quad{ }_{w}$ que define a amplitude do fator de penalização deve variar consideravelmente conforme características da classe buscada e da estrutura da rede utilizada. Assim, um mecanismo para a determinação dinâmica de ${ }_{w}$ baseado exclusivamente no comportamento do classificador foi concebido.

A amplitude será representada pela função ${ }_{w}: \mathbb{N} \mapsto(0,1]$ para evidenciar sua dinamicidade em relação ao tempo: ${ }_{w}(t)$. A amplitude é iniciada com um valor alto, por exemplo ${ }_{w}(0)=1$. Lembrando que os pesos $w_{j}$ são iniciados dentro da bacia de atração $B_{0}$, a amplitude é decrementada enquanto todos os pesos $w_{j}$ estiverem em $B_{0} \mathrm{e}$ é mantida constante caso contrário. Este critério é utilizado para trazer a amplitude a um valor ou magnitude que esteja condizente (balanceado) com o algoritmo de treinamento. A quantidade utilizada para decrementar o valor da amplitude é proporcional à diferença entre esta e o custo gerado pelo peso de maior magnitude.

Sejam $w_{M}=\max _{j}\left\{\left|w_{j}\right|\right\}$ o peso de maior magnitude e $\bar{c}_{w}\left(w_{M}\right)$ o custo a ele associado, dado por (4.9), a atualização da amplitude é realizada por:

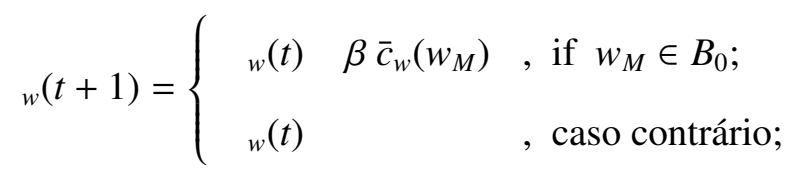

onde $0<\beta \in \mathbb{R}$ é o fator de decréscimo da amplitude. Note que novamente trocamos um parâmetro por outro, mas ao contrário de ${ }_{w}$, o novo parâmetro $\beta$ pode ser tido 
como uma constante na ordem da grandeza de $10{ }^{4}$ para os casos testados.

\subsubsection{Considerações sobre o classificador}

Nesta seção ressaltaremos alguns pontos interessantes acerca do classificador e do mecanismo de poda utilizado para a determinação dinâmica de sua estrutura tendo em vista o paradigma do DCAA.

- Apesar de estarmos utilizando o conceito de poda, como os elementos associados a pesos $w_{j} \in B_{0}$ são tidos como supérfluos e como todos os pesos w são iniciados em $B_{0}$ a poda da rede inicial resulta em uma rede sem elementos na camada oculta. Assim, também se pode interpretar que a constituição da rede se dá por um mecanismo incremental e não de poda, visto que novos elementos são tidos como importantes (adicionados) conforme saem da bacia $B_{0}$.

- Outro ponto é que não se está pensando na determinação dinâmica dos elementos da camada oculta como uma forma de diminuir o esforço computacional exigido no treinamento ou uso da rede, mas como uma forma de encontrar um número adequado de elementos que permitam à rede representar a classe evitando tanto o problema de incapacidade de representação advindo do uso de poucos elementos, quanto o problema de over-fitting advindo do uso de muitos elementos.

- Um terceiro ponto é o de que os elementos ocultos supérfluos na constituição de uma classe (uma saída da rede) são mantidos na estrutura da rede porque podem ser importantes para o caso de regiões do domínio ainda não amostradas se apresentarem em um tempo futuro. Também, os elementos tidos como supérfluos para uma classe podem ser usados na delineação de outras classes do mesmo domínio que inclusive podem ser apresentadas apenas em um tempo futuro. 


\subsection{Mecanismo de identificação de descontiguidades}

Além do mecanismo de classificação exposto na Seção 4.2, fundamental para a constituição dos átomos de causalidade, a construção do grafo sensório-motor proposto nesta tese necessita de um mecanismo que implemente o processo de divisão exposto na Seção 3.2.5. Este mecanismo de divisão se faz chave na construção do esquema pois é ele que permite o encadeamento dos átomos não restringir a estrutura resultante a uma lista. A divisão expande o encadeamento para uma estrutura de árvore computacional.

O principal papel do mecanismo de divisão pode ser visto como o de manter a simplicidade das classes que representam os átomos de causalidade, daí a utilização de dois ou mais subconjuntos com topologias mais simples para representar a classe ao invés de um único conjunto com topologia complexa. Seguindo nesta linha, o mecanismo aqui proposto encontra os subconjuntos contíguos que formam a classe. Estes subconjuntos serão então utilizados para quebrar a represenção da classe em partes mais simples, tendo a contiguidade como critério para o que se tem como sendo simples.

Nesta seção mostraremos como o mecanismo de divisão foi implementado. Este mecanismo tem como base o classificador proposto na Seção 4.2 e foi projetado para ser acoplado às conexões entre a camada oculta e a camada de saída da RNAFF-1 que implementa o classificador.

\subsubsection{Estrutura}

O mecanismo de deteção de descontiguidade está acoplado à RNA subjacente ao classificador e se baseia nas influências que as saídas dos elementos da camada oculta têm sobre o delineamento da classe descrita pelo classificador. Como o mecanismo foi projetado para explicitar as expressões dos elementos da camada oculta na formação dos blocos básicos que constituem a classe resultante suas entradas se atêm às conexões 
que ligam a camada oculta à camada de saída da rede como ilustra a Figura 9.

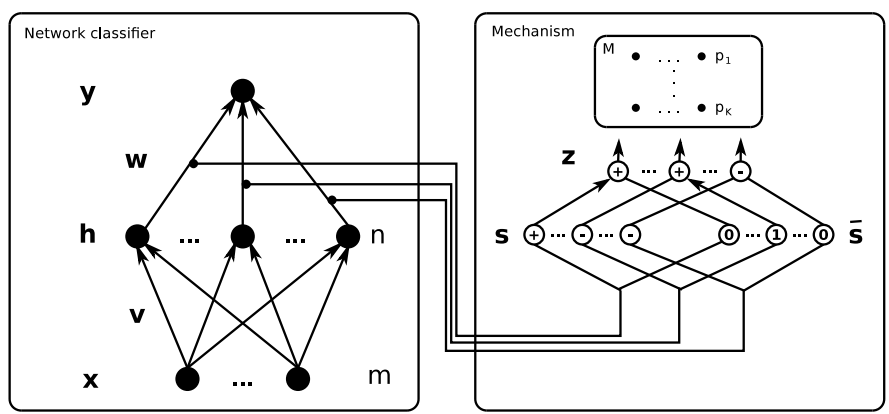

Figura 9: Acomplamento do mecanismo de identificação de descontiguidades à estrutura da RNA subjacente ao classificador. O mecanismo se utiliza das influências da camada oculta da rede para encontrar as métricas $\mathbf{s} \in\{1,+1\}^{n}$ e $\overline{\mathbf{s}} \in\{0,1\}^{n}$ utilizadas na geração das entradas $\mathbf{z} \in\{1,+1\}^{n}$ do mapa de características $M$ incumbido de representar as descontiguidades da classe associada.

Assim como o mecanismo de poda proposto na Seção 4.2 atua na estrutura da RNA utilizada pelo classificador, mas não depende do algoritmo utilizado para o treinamento da rede, o mecanismo de identificação das descontiguidades aqui proposto também independe do algoritmo de treinamento, ou mesmo do mecanismo de poda. Em conformidade com o mecanismo de poda (4.1), a seguinte notação será utilizada para expressar os estados da RNA do classificador subjacente:

$$
\begin{aligned}
y(\mathbf{x}) & =f(u(\mathbf{x})) ; \\
u(\mathbf{x}) & =b+\mathbf{w}^{T} \mathbf{h}(\mathbf{x}) ; \\
h_{j}(\mathbf{x}) & =f\left(a_{j}+\mathbf{V}_{\mathbf{j}}^{T} \mathbf{x}\right) ; \quad j=1, . ., n ;
\end{aligned}
$$

onde: $u: \mathbb{R}^{m} \mapsto \mathbb{R}$ expressa o valor que chega à saída do classificador. Note que de (4.1) foi acrescentada apenas a expressão para $u(\mathbf{x})$.

Aqui também se faz importante definir o conjunto dos pontos que representam a classe expressada pela RNA do classificador, dado por:

$$
C=\{\mathbf{x} \in D \mid y(\mathbf{x})>0\}
$$

O mapeamento das combinações das influências dos elementos da camada oculta 
à constituição da classe é representado pelo mapa $M=\left\{\mathbf{p}_{1}, \ldots, \mathbf{p}_{\mathbf{K}}\right\} \subset \mathbb{R}^{n}$. Note que se está associando um mapa a cada classe alvo do classificador. Cada elemento $\mathbf{p}_{\mathbf{k}}$ representa uma região no espaço das entradas do mapa. Seu significado ficará claro mais adiante quando da explanação das dinâmicas do mapa.

Cada mapa possui uma energia associada que é utlizada para determinar a plasticidade da estrutura do mapa de forma que tanto as inserções quanto as remoções de elementos são realizadas apenas em estados de baixa energia. O cálculo da energia $E_{M}: \mathbb{N} \mapsto[0,1] \subset \mathbb{R}$ do mapa $M$ é feito para que ela represente a frequência mais recente dos erros acometidos pelo classificador na previsão da classe, e é dado por:

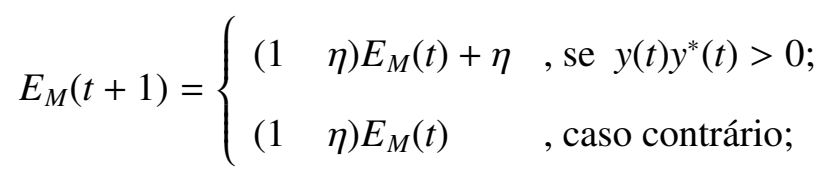

onde:

- $t \in \mathbb{N}$ : instante de tempo;

- $\eta \in(0,1)$ : taxa de modificação da energia do mapa;

- $y(t) \in \mathbb{R}$ : saída do classificador no instante $t$;

- $y^{*}(t) \in\{1,+1\}$ : valor da classe no instante $t$;

- $E_{M}(0)=1$.

Por (4.14) pode-se perceber que a energia do mapa se mantém alta enquanto o classificador não consegue mapear a classe, e diminui à medida em que o classificador aumenta sua performance.

\subsubsection{Entradas do mapa}

As entradas $\mathbf{z} \in \mathbb{R}^{n}$ utilizadas para o treinamento do mapa são construídas de forma a representar as influências positivas, $\mathbf{s}$, e as influências negativas, $\overline{\mathbf{s}}$, que a 
saída de cada elemento da camada oculta $h_{j}(\mathbf{x})$ da RNA tem na determinação da classe delineada pelo classificador.

As contribuições positivas $\mathbf{s} \in \mathbb{R}^{n}$ dos elementos da camada oculta $\mathbf{h}$ são dadas por:

$$
s_{j}=w_{j} h_{j} \quad ; j=1, \ldots, n .
$$

Note que quando $s_{j}>0, \mathrm{o} j$-ésimo elemento da camada oculta está aumentando o valor de $u(\mathbf{x})$ definido em (4.13), daí sua contribuição ser tida como positiva.

Note que se acaso a função $f$ de ativação dos elementos das saídas da rede fosse linear, as contribuições positivas seriam as únicas contribuições que os elementos ocultos teriam na formação da classe. Porém, como a função de ativação $f$ é não-linear e monotonicamente crescente, $f()=.\tanh ($.$) , os elementos ocultos h_{j}$ contribuem para a constituição da classe mesmo quando $s_{j} \leq 0$, o que nos leva à consideração das contribuições negativas $\overline{\mathbf{s}} \in\{0,1\}^{n}$, definidas por:

$$
\bar{s}_{j}= \begin{cases}1 & , \text { se } s_{j}>u(\mathbf{x}) \quad 1, \\ 0 & , \text { caso contrário, }\end{cases}
$$

onde $u(\mathbf{x})$ dado por (4.13) é o valor de entrada do elemento de saída da rede associado à classe alvo do mapa.

O elemento oculto $h_{j}$ exerce uma influência negativa $\bar{s}_{j}$ quando para alguma entrada $\mathbf{x}$ do classificador se tem $u(\mathbf{x})=b+\mathbf{w}^{T} \mathbf{h}(\mathbf{x})>0$, mas se hipoteticamente fizéssemos $h_{j}=1$, então teríamos $u(\mathbf{x}) \leq 0$. Em outras palavras, mesmo que o elemento oculto $h_{j}$ não contribua positivamente $\left(s_{j}=w_{j} h_{j}<0\right)$ para a inclusão da entrada $\mathbf{x}$ à classe, considera-se importante sua influência quando notado que $\mathbf{x}$ é excluída da classe quando $h_{j}$ assume seu menor valor $h_{j}=1$. Dito de outra forma, apesar da amostra $\mathbf{x}$ ser tida como pertencente à classe com $h_{j}$ contribuindo negativamente, $\mathbf{x}$ não seria tida como pertencente à classe para o caso de $h_{j}=1$. Nestas condições, mesmo que a contribuição de $h_{j}$ não seja positiva $\left(s_{j}<0\right)$ sua influência negativa $\bar{s}_{j}$ é 
tida como importante para a constituição da classe.

As entradas $\mathbf{z}$ do mapa, como ilustrado na Figura 9 são obtidas pela composição das contribuições positivas e negativas, e definidas por:

$$
z_{j}=\left\{\begin{aligned}
+1 & , \text { se }\left(s_{j}>0\right) \vee\left(\bar{s}_{j}=1 \wedge|\bar{s}|=1\right) ; \quad ; j=1, \ldots, n . \\
1 & , \text { caso contrário; }
\end{aligned}\right.
$$

Note que as contribuições negativas $\overline{\mathbf{s}}$ estão restritas a situações onde apenas um elemento da camada oculta manifesta uma contribuição negativa, expressado pela condição: $|\bar{s}|=1$.

\subsubsection{Atualização dos elementos.}

Os elementos do mapa são atualizados seguindo a abordagem winner-takes-all. A cada iteração é atualizado apenas o elemento mais próximo à entrada do mapa. Desta forma, dada a entrada $\mathbf{z} \in\{1,+1\}^{n}$ do mapa, encontra-se o elemento vencedor $\overline{\mathbf{p}} \in M$ mais próximo a $\mathbf{z}$ segundo a distância de Chebyshev²

$$
\|\overline{\mathbf{p}} \quad \mathbf{z}\|_{\infty}=\min _{1 \leq k \leq K}\left\{\left\|\mathbf{p}_{\mathbf{k}} \quad \mathbf{z}\right\|_{\infty}\right\}
$$

O elemento vencedor $\overline{\mathbf{p}}$ é então atualizado na direção da entrada $z$ segundo:

$$
\overline{\mathbf{p}}(t+1)=\left(\begin{array}{ll}
1 & \gamma
\end{array}\right) \overline{\mathbf{p}}(t)+\gamma \mathbf{z},
$$

onde $\gamma \in(0,1)$ é o coeficiente de atualização dos elementos de $M$.

\subsubsection{Modificação da estrutura}

O número de elementos que compõem o mapa é fortemente dependente da topologia da classe alvo do classificador, desconhecida a priori. Como não há como saber de antemão o número de elementos necessários para que o mapa se adeque à estrutura na qual a rede subjacente se estabilizará, mecanismos para criar e remover dinamicamente

\footnotetext{
${ }^{2}$ A distância de Chebyshev entre os pontos $\mathbf{a}, \mathbf{b} \in \mathbb{R}^{n}$ é definida por: $\|\mathbf{a} \quad \mathbf{b}\|_{\infty}=\max _{1 \leq j \leq n}\left\{\left|a_{j} \quad b_{j}\right|\right\}$.
} 
elementos do mapa se fazem necessários.

O mapa possui uma energia associada que regula os momentos nos quais os mecanismos de modificação dinâmica da estrutura do mapa são utilizados. Ou seja, a energia do mapa dita a plasticidade de sua estrutura. Novos elementos são inseridos ou elementos já existentes são removidos apenas quando a energia do mapa está abaixo do limite $L_{e} \in(0,1)$ :

$$
E_{M}(t)<L_{e}
$$

Note que por (4.14) a energia do mapa $E_{M}$ é proporcional à taxa dos erros mais recentes do classificador em delinear sua classe alvo. Assim, o parâmetro $L_{e}$ estipula o quão bem sucedido o classificador deve estar para que sua estrutura possa ser modificada. Este mecanismo evita a estabilização precoce dos elementos do mapa a estruturas passageiras da rede.

Após alguma modificação estrutural do mapa é preciso que haja um intervalo de tempo para que a nova composição formada pelos elementos preexistentes em conjunto com os novos elementos possam se reestruturar encontrando um novo equilíbrio, é preciso um tempo para a reequilibração. Para isso foi projetado o mecanismo de fadiga.

O mecanismo de fadiga é implementado pela elevação abrupta da energia do mapa a toda vez que novos elementos são inseridos ou elementos existentes são removidos. Dito de outra forma, a energia é aumentada toda vez que o número de elementos que compõem o mapa, representado por $|M(t)|$, é modificado. Tal mecanismo é estabelecido por:

$$
E_{M}(t+1)= \begin{cases}1 & , \text { se }|M(t+1)| \quad|M(t)| \\ E_{M}(t) & , \text { caso contrário. }\end{cases}
$$

Assim como o mapa, cada elemento que o compõe possui uma energia associada. A energia $E_{p}: \mathbb{N} \mapsto[0,1] \subset \mathbb{R}$ associada ao elemento $\mathbf{p} \in M$ reflete sua taxa mais 
recente de ativação e é definida por:

$$
E_{p}(t+1)=\left\{\begin{array}{lll}
(1 & ) E_{p}(t)+ & , \text { se } \mathbf{p} \text { é o vencedor } \\
(1 & ) E_{p}(t) & , \text { caso contrário. }
\end{array}\right.
$$

onde $E_{p}(0)=0.5$ e $\in(0,1)$ é o coeficiente de atualização das energias dos elementos.

A energia dos elementos do mapa desempenha papel fundamental nos critérios utilizados tanto na adição quanto na remoção dos elementos do mapa, apresentados a seguir. Também, note que os mapas são iniciados, em $t=0$, com um único elemento $M(0)=\left\{\mathbf{p}_{\mathbf{1}}\right\}$ e que a plasticidade de sua estrutura se deve a estes dois mecanismos.

\subsubsection{Adição de elementos.}

O mapa é iniciado com um único elemento que passa a ser atualizado com os valores de entrada $\mathbf{z}$ obtidos por (4.17). A atualização dos elementos $\mathbf{p}$ do mapa feita por (4.19) os leva a convergir para a média dos pontos de entrada que os influenciam, consequência da utilização da abordagem winner-takes-all, implementada por (4.18). A convergência dos elementos $\mathbf{p}$ é utilizada para perceber a diversidade das entradas $\mathbf{z}$ que o influenciam. Visto que $\mathbf{z} \in\{1,+1\}^{n}$, a distância de $\mathbf{p}$ ao domínio de entrada $\{1,+1\}^{n}$ é utilizada como métrica para se estabelecer o conceito de instabilidade de um elemento.

A existência de elementos instáveis indica a necessidade de expansão do mapa. O elemento $\mathbf{p} \in M$ é considerado instável quando converge para valores distintos de $\{1,+1\}^{n}$. Tal critério é regrado pelo limite de estabilidade $L_{s} \in(0,1)$ e estabelecido pela condição:

$$
\min _{1 \leq j \leq n}\left\{\left|p_{j}\right|\right\}<L_{s}
$$

Note que o critério de estabilidade aplicado a um elemento pressupõe sua convergência. Faz-se necessário, então, saber quando um elemento do mapa já convergiu, ou se ainda se encontra a caminho de alguma estabilização. Para isto é utilizado o 
conceito de maturidade.

O elemento $\mathbf{p} \in M$ é considerado maduro se sua energia $E_{P}$ está acima do limite de maturidade $L_{m} \in(0,1)$, ou seja, se:

$$
E_{p}(t)>L_{m}
$$

Um novo elemento é criado e inserido em $M$ se existe algum elemento $\mathbf{p} \in M$ maduro (4.24) e instável (4.23) quando a energia do mapa satisfaz a condição de plasticidade estabelecida por (4.20). Então, o novo elemento $\mathbf{q} \in \mathbb{R}^{n}$ é criado seguindo:

$$
q_{j}=\left\{\begin{array}{ll}
p_{j} & , \text { se }\left|p_{j}\right|<L_{s} ; \\
p_{j} & , \text { caso contrário. }
\end{array} \quad ; j=1, \ldots, n .\right.
$$

Note que q é gerado a partir do elemento instável $\mathbf{p}$ e que as coordenadas que caracterizam p como instável são colocadas em quadrantes opostos (negadas). Assim, q estará buscando representar justamente os espaços que tornam p instável. Observe também que após a criação do novo elemento, o mecanismo de fadiga (4.21) entra em ação permitindo que tanto q quanto $\mathbf{p}$ tenham tempo de atingir novos equilíbrios.

\subsubsection{Remoção de elementos.}

O elemento $\mathbf{p} \in M$ é removido do mapa quando considerado desnecessário à dinâmica do mapa. Tal situação é estabelecida quando a energia $E_{p}(t)$ está abaixo do limite de existência $L_{d} \in(0,1)$, condição dada por:

$$
E_{p}(t)<L_{d}
$$

Note que assim como ocorre na inserção de novos elementos, quando um elemento é removido do mapa sua energia $E_{M}$ é atualizada pelo mecanismo de fadiga (4.21) permitindo aos elementos restantes se reestruturarem antes de novas modificações da estrutura do mapa serem permitidas. 


\subsubsection{Identificação dos subconjuntos contíguos e convexos}

Cada mapa $M$ se utiliza das influências dos elementos da camada oculta da rede para criar, manter e remover os elementos que o formam. Relembrando que o papel do mapa é o de possibilitar a percepção dos subconjuntos contíguos que formam a classe a ele associada veremos agora como os elementos são capazes de representar os subconjuntos convexos da classe e como é possível identificar a descontiguidade destes subconjuntos que constituem a classe.

Cada elemento do mapa representa um subconjunto convexo que compõe a classe alvo. A determinação da contiguidade dos conjuntos convexos representados pelos elementos $\mathbf{p}, \mathbf{q} \in M$ é dada pela função $d: \mathbb{R}^{2 n} \mapsto\{0,1\}^{n}$, definida por:

$$
d_{j}(\mathbf{p}, \mathbf{q})=\left\{\begin{array}{ll}
1 & , \text { se } p_{j} . q_{j} \leq 0 ; \\
0 & , \text { caso contrário; }
\end{array} \quad ; j=1, \ldots, n .\right.
$$

A função $d$ é utilizada para expressar as diferenças entre dois elementos do mapa sendo a norma $\|d(\mathbf{p}, \mathbf{q})\|_{1}{ }^{3}$. utilizada para expressar a distância entre os dois elementos.

Perceba que cada elemento do mapa define um subconjunto convexo da classe ao armazenar quais elementos da camada oculta influenciam e quais não influenciam a classe. O subconjunto convexo $S_{p} \subset C$ da classe $C$ associado ao elemento $\mathbf{p} \in M$ é definido por:

$$
S_{p}=\left\{\mathbf{x} \in C \mid\|d(\mathbf{p}, \mathbf{z}(\mathbf{x}))\|_{1}=0\right\}
$$

Onde $z_{j}(\mathbf{x})$ dado por (4.17) é a influência do $j$-ésimo elemento oculto na constituição da classe $C$ quando a entrada $\mathbf{x}$ é apresentada à rede.

Da mesma forma que a norma $\|d(.)\|_{1}$ é utilizada para definir os subconjuntos convexos associados ao elementos, ela também é utilizada para encontrarmos a contiguidade entre os subconjuntos. Os subconjuntos convexos $S_{p}, S_{q} \subset C$ associados,

\footnotetext{
${ }^{3}$ A métrica de distância $L_{1}$ entre dois pontos $\mathbf{a}, \mathbf{b} \in \mathbb{R}^{n}$ é definida como: $\|\mathbf{a} \quad \mathbf{b}\|_{1}=\sum_{j=1}^{n}\left|a_{j} \quad b_{j}\right|$. Também: $\|\mathbf{a}\|_{1}=\sum_{j=1}^{n}\left|a_{j}\right|$.
} 
respectivamente, aos elementos $\mathbf{p}, \mathbf{q} \in M$ são tidos como contíguos se:

$$
\|d(\mathbf{p}, \mathbf{q})\|_{1} \leq 1
$$

Expandindo (4.29) tem-se que o conjunto formado pelos subconjuntos convexos $P \subseteq M$ é contíguo se:

$$
\|d(\mathbf{p}, \mathbf{q})\|_{1} \leq 1, \quad \forall \mathbf{p}, \mathbf{q} \in P .
$$

Da mesma forma, os conjuntos $P, Q \subset M$ formados por subconjuntos convexos são tidos como não contíguos se:

$$
\|d(\mathbf{p}, \mathbf{q})\|_{1}>1, \quad \forall \mathbf{p} \in P, \forall \mathbf{q} \in Q
$$

Perceba que o critério de descontiguidade (4.31) não é teoricamente rigoroso

Por (4.29), (4.30) e (4.31) pode-se determinar a qualquer instante os subconjuntos contíguos e os convexos que compõem a classe segundo a estrutura do mapa à classe associado.

\subsubsection{Sobre os parâmetros do mecanismo}

O mecanismo de identificação de descontiguidades proposto se utiliza de 7 parâmetros sendo que , $\eta$ e $\gamma$ desempenham papeis de coeficientes de atualização e $L_{e}, L_{s}$, $L_{m}$ e $L_{d}$ são utilizados como limiares que regulam o comportamento do mapa.

Note que apesar da necessidade de que o projetista determine os valores dos parâmetros parecer estar desconforme ao princípio do DCAA, na realidade estes parâmetros podem ter seus valores fixados para todos os experimentos realizados permitindo que sejam pensados mais como características intrínsicas do que como parâmetros. A seguir veremos com um pouco mais de detalhes os papéis dos 4 limiares utilizados.

$\boldsymbol{L}_{e}$ : limiar de energia do mapa que define sua plasticidade, ou seja, apenas mapas com energia inferior a este limite podem ter suas estruturas modificadas pela 
adição de novos elementos ou remoção de elementos supérfluos. Este limiar tem o papel de permitir que os elementos do mapa possam se estabilizar antes de modificações estruturais do mapa.

$\boldsymbol{L}_{s}:$ define quando um elemento do mapa é tratado como instável. Os elementos instáveis são aqueles influenciados por entradas $\mathbf{z}$ representando mais de um subconjunto convexo. Assim, este limite tem a função de indicar qual a tolerância da influência cruzada dos subconjuntos convexos antes de gerar novos elementos para tratarem parte destas influências. Valores baixos indicam pouca tolerância.

$\boldsymbol{L}_{\boldsymbol{m}}$ : é o limiar de maturidade dos elementos do mapa. Apenas elementos instáveis com energia superior a este limiar são utilizados para gerar novos elementos.

$\boldsymbol{L}_{d}$ : é o limiar de existência dos elementos do mapa. Elementos com energia abaixo deste limiar, ou seja, com baixíssimas taxas de ativação são considerados supérfluos e são removidos do mapa.

\subsubsection{Considerações sobre o mecanismo}

O mecanismo proposto é capaz de encontrar como os elementos da camada oculta de uma RNAFF-1 classificatória são combinados para expressar os conjuntos convexos e contíguos que formam a classe. O mecanismo foi concebido para se utilizar de amostras da classe em fluxo contínuo (on-line) e é capaz de se manter adaptado à estrutura da rede mesmo que esta esteja em constante modificação. Como consequência, o mecanismo pode ser utilizado por outros sistemas computacionais que sigam o paradigma do DCAA. Mesmo utilizando parâmetros regulatórios, o comportamento do mecanismo não é comprometido por seus valores que por isto não precisam ser modulados para cada tarefa.

O mecanismo possui 2 pontos fracos. Primeiro, o número de elementos de um mapa pode crescer até o limite $2^{n}$, onde $n$ é o número de elementos da camada oculta. 
Porém, a situação na qual os mapas apresentam muitos elementos, mais propícia a ocorrer quando as classes são côncavas, não parece ser muito comum. Em segundo lugar, como o mecanismo de remoção dos elementos utiliza como critério as frequências mais recentes de ativação, mesmo subconjuntos convexos com grandes regiões podem não ser encontrados se tiverem baixa frequência de amostragem.

\subsection{Grafo sensório-motor}

A implementação do esquema cognitivo segue o modelo teórico de construção do grafo sensório-motor (GSM) exposto na Seção 3.2. As decisões importantes, do ponto de vista da implementação se relacionam às operações referentes ao átomo de causalidade: encadeamento, treinamento, divisão e fusão.

Antes de adentrarmos na implementação do GSM, e até para facilitar seu entendimento, ressaltaremos os princípios de organização progressiva e de delegação da motivação utilizados na concepção das implementações computacionais desenvolvidas.

Primeiramente, note que na implementação do classificador da Seção 4.2, para o estabelecimento autônomo do número de elementos necessários à camada oculta, a estrutura da rede começa com um número superestimado de elementos sendo que no início nenhum deles é utilizado. Então, o algoritmo de poda passa a incluir os elementos da camada oculta que estejam associados a pesos $w_{j}$ que escapam da bacia de atração $B_{0}$, ou seja: $w_{j} \notin B_{0}$. Perceba que há uma organização progressiva dos componentes de uma estrutura previamente sobre-estimada. O princípio de organização progressiva também é utilizado para a constituição do GSM. Neste caso, a rede é iniciada também com um número sobre-estimado de elementos na camada de saída. Estes elementos são então progressivamente recrutados para desempenharem o papel dos nós do GSM conforme este se organiza. 
Em segundo lugar, o classificador utiliza o motivador externo $y^{*}(t)$ para a organização de sua estrutura para determinar quando a amostra $\mathbf{x}(t)$ pertence ou não à classe em questão. A estrutura que gera os valores de $y^{*}(t)$ é justamente o GSM, estabelecendo a relação de uso do classificador, pois gera a motivação que este utiliza para se organizar. Este princípio de delegação da motivação que estabelece a relação de uso entre duas estruturas também é utiliza pelo GSM. Porém, no caso do GSM o agente externo utilizado para a organização de sua estrutura é seu objetivo sensório, $E^{*}$, já descrito na Seção 3.2.1.

Nesta seção veremos como a estrutura inicial de uma RNAFF-1 com um número sobre-estimado de elementos nas camadas oculta e de saída é modificada para representar um GSM utilizando os elementos da camada de saída como nós do grafo por meio da organização progressiva, delegando a motivação para sua organização ao seu objetivo sensório.

Note que os dois princípios podem ser aplicados a outros mecanismos que usem o GSM pela geração do seu motivador externo $E^{*}$, aumentando a estrutura organizacional do sistema, mas que fogem ao escopo desta tese. Algumas indicações sobre tais possíveis mecanismos são apresentadas quando das considerações finais na Seção 6.1.

\subsubsection{Estrutura}

A estrutura básica do GSM é dada por uma rede RNAFF-1. Cada elemento de saída $y_{k}$ constitui um classificador, como exposto na Seção 4.2. Também, a cada conjunto de conexões que chegam aos elementos de saída $W_{k}$ é acoplado o mapa $M_{k}$ que implementa o mecanismo de identificação de descontiguidades descrito na Seção 4.3. A esta estrutura são acrescentados o objetivo do esquema $E^{*}$ e as conexões $R$ entre os elementos de saída que representam os arcos do GSM. A Figura 10 mostra a estrutura do GSM. Note que os classificadores compartilham os elementos da camada oculta. Outro ponto a ser notado é que as saídas y da RNA não estão diretamente associadas 


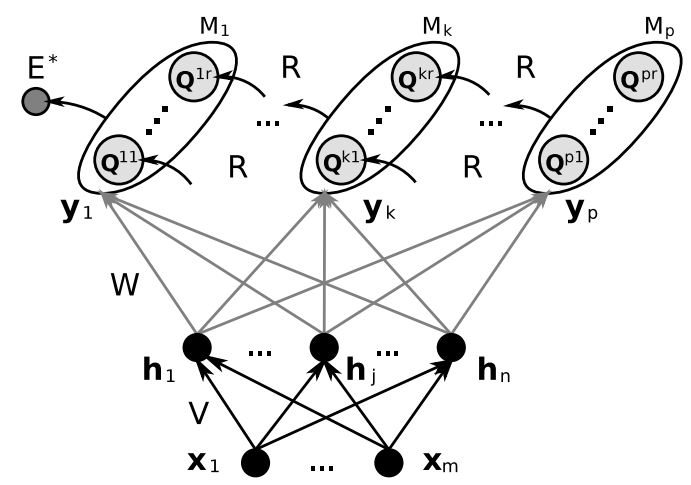

Figura 10: Estrutura do GSM que representa o esquema utilizando as saídas da RNAFF-1 do classificador para a constituição do grafo. $E^{*}$ indica o objetivo externo do esquema.

aos nós do grafo. Por motivos didáticos estas associações serão expostas apenas na Seção 4.4.2 quando trataremos do treinamento do grafo.

A estrutura do GSM é definida por:

$$
G=\left[D, E^{*}, R N A, Q, R\right]
$$

onde:

- $D \subset[1,+1]^{m}:$ domínio sensório motor de entrada, $D=S \times A$;

- $E^{*} \subset S$ : objetivo sensório do esquema, seu motivador externo;

- RNA: rede neural do tipo RNAFF-1 com $m$ entradas, $n$ elementos na camada oculta e $p$ elementos de saída;

- $Q$ : conjunto dos nós que compõem o grafo. A notação $Q^{k i}$ é utilizada para designar o $i$-ésimo nó gerado pela $k$-ésima saída da RNA, $y_{k}$, ou seja, o $i$-ésimo conjunto contíguo encontrado pelo $k$-ésimo mapa do mecanismo de desontiguidade. Também, $Q^{k}$ é utilizado para designar o conjunto de nós $\left\{Q^{k i}\right\}_{i}$ gerados por $y_{k}$, ou seja, sua classe.

- $R$ : conjunto dos arcos que compõem o grafo. A notação $R_{q}^{k i}$ é utilizada para designar o arco com origem na classe $Q^{q}$ e destino no nó $Q^{k i}$. 
Um outro ponto as ser notado é que, diferentemente das notações utilizadas nas Seções 4.2.3.1 e 4.3.1, está se utilizando $p$ saídas ao invés de apenas uma. Como consequência também são expandidos os pesos das conexões entre a camada oculta e a saída, antes representados pelo vetor $\mathbf{w}$ e agora representados pela matriz $W$. As saídas da RNA utilizada pelo GSM são calculadas de forma padrão às RNAFF-1, ou seja:

$$
\begin{aligned}
y_{k} & =f\left(u_{k}\right) ; \quad k=1, . ., p ; \\
\mathbf{u} & =\mathbf{b}+W^{T} \mathbf{h} ; \\
h_{j} & =f\left(a_{j}+\mathbf{V}_{\mathbf{j}}^{T} \mathbf{x}\right) ; \quad j=1, . ., n ;
\end{aligned}
$$

onde:

- $\mathbf{y} \in \mathbb{R}^{p}$ : saídas da rede, RNAFF-1.

- $f: \mathbb{R} \mapsto(1,+1)$ : função de ativação dos elementos da rede, $f()=.\tanh ($.$) ;$

- $u \in \mathbb{R}^{p}$ : influências dos elementos das camadas oculta que chegam aos elementos da camada de saída;

- $\mathbf{b} \in \mathbb{R}^{p}$ : bias dos elementos da camada de saída;

- $W \in \mathbb{R}^{n \times p}:$ pesos das conexões entre a camada oculta e a saída;

- $\mathbf{h} \in(1,+1)^{n}:$ saídas da camada oculta;

- $\mathbf{a} \in \mathbb{R}^{m}$ : bias dos elementos da camada oculta;

- $V \in \mathbb{R}^{m \times n}:$ pesos das conexões entre a camada de entrada e a oculta sendo que o vetor coluna $\mathbf{V}_{\mathbf{j}} \in \mathbf{R}^{m}$ representa os pesos das conexões da entrada ao $j$-ésimo elemento da camada oculta;

- $\mathbf{x} \in D$ : entradas do classificador.

Apenas para simplificar a notação retiramos a dependência da entrada $\mathbf{x}$ das funções $\mathbf{y}(\mathbf{x}), \mathbf{u}(\mathbf{x})$ e $\mathbf{h}(\mathbf{x})$, notando-as simplesmente pelas variáveis $\mathbf{y}, \mathbf{u}$ e $\mathbf{h}$, respectivamente. 
Formalmente, a relação entre as saídas da rede y e o conjunto $Q^{k} \subset D$ é definida por:

$$
Q^{k}=\bigcap_{i} Q^{k i}=\left\{\mathbf{x} \in D \mid y_{k}(\mathbf{x})>0\right\}
$$

\subsubsection{Treinamento}

O grafo GSM é iniciado com o objetivo sensório $E^{*}$ e com a estrutura de uma rede, RNAFF-1, com pesos e bias gerados aleatoriamente seguindo o critério de iniciação dos classificadores ${ }^{4}$, como exposto na Seção 4.2.3. Inicialmente $E^{*}$ é o único nó do grafo e, portanto, ainda não há arcos.

Veremos agora como o motivador externo $E^{*}$ é utilizado pelo mecanismo de treinamento, tanto na constituição das dinâmicas que modificam a estrutura do grafo, quanto no treinamento das estruturas estabelecidas.

\subsubsection{Dinâmicas da estrutura}

O primeiro arco do grafo é gerado associando a saída $y_{1}$ da rede ao seu objetivo $E^{*}$. Então, a estrutura do classificador relacionada a $y_{1}$ passa a ser treinada para conter as situações sensório-motoras $\mathbf{x}_{t 1}=\left[\mathbf{s}_{t}{ }_{1}, \mathbf{a}_{t}{ }_{1}\right] \in D \subset \mathbb{R}^{m}$ que percebem a ativação de $E_{t}^{*}$, ou seja, quando $\mathbf{s}_{t 1} \notin E_{t 1}^{*} \wedge \mathbf{s}_{t} \in E_{t}^{*}$.

Como consequência dos mecanismos de classificação, expostos na Seção 4.2, e dos mecanismos de identificação de descontiguidades expostos na Seção 4.3, os subconjuntos contíguos que formam a classe representada pela saída $y_{1}$ são identificados pelo mapa $M_{1}$ associado, e notados por $Q^{1}$. De forma geral, utilizaremos a notação $Q^{k i} \subset D$ para representar o contexto sensório-motor ${ }^{5}$ dos átomos de causalidade do esquema descritos na Seção 3.1.1 que são implementados pelo $i$-ésimo subconjunto

\footnotetext{
${ }^{4}$ Os pesos das conexões entre a camada oculta e a de saída são gerados na bacia de atração $B_{0}$ que contém a origem por: $\left|W_{j, k}\right|<\tau / 4 ; 0<j \leq n, 0<k \leq p$.

${ }^{5}$ Note que $D$ representa o espaço de entrada da rede que é o mesmo espaço de entrada do esquema $S \times A$.
} 
contíguo da classe delineada pela saída $y_{k}$ (veja a Figura 10).

Assim como $E^{*}$ é utilizado como o objetivo da classe associada a $y_{1}$, cada $Q^{k i}$ é utilizado para gerar o objetivo de uma nova classe implementada pelo recrutamento de alguma saída da rede $y_{q}$ que ainda não tenha sido utilizada pelo GSM. Note que enquanto $E^{*} \subset S$ onde $S$ é o espaço sensório do esquema, $Q^{k i} \subset S \times A$ onde $A$ é o espaço motor. Daí, o objetivo gerado por $Q^{k i}$ é obtido por sua projeção no espaço sensório $S$ e é representado por $Q_{S}^{k i}$. A associação da nova classe $y_{p}$ ao objetivo $Q_{S}^{k i}$ é estabelecida pela criação no grafo do arco $R_{q}^{k i}$ que tem como origem todos os subconjuntos contíguos que compõem a classe $y_{q}$, representados por $Q^{q}$, e como destino o subconjunto $Q^{k i}$, mostrado na Figura 10. Sendo o objetivo sensório de $Q^{q s}$ representado por $Q_{O}^{q}$, tem-se ${ }^{6}$ :

$$
\begin{aligned}
Q_{O}^{q} & =\left\{\begin{array}{l}
E^{*}, \text { se } q=1 ; \\
Q_{S}^{k i}, \text { se } \exists R_{q}^{k i}, 1<q \leq p ;
\end{array}\right. \\
Q_{S}^{k i} & =\operatorname{proj}_{S}\left(Q^{k i}\right)
\end{aligned}
$$

A inclusão da nova saída $y_{q}$ ao grafo faz com que também os pesos $W_{q}$ das conexões a ela associadas passem a fazer parte do sistema. Note que estas ligações estão associadas a todos os elementos da camada oculta, inclusive os que já estão participando na constituição de outras classes ${ }^{7}$. Desta forma, as partições do domínio de entrada $D$, já estabelecidas por estes elementos participantes podem ser reaproveitadas para a constituição da nova classe $y_{q}$ agilizando o processo de delineamento das classes conforme o grafo se organiza.

Um ponto importante é que para serem considerados neste processo de organização estrutural do GSM, tanto as classes como os subconjuntos contíguos detetados devem ser considerados estáveis, o que é realizado pelo próprio mecanismo de identi-

\footnotetext{
${ }^{6}$ Note que todos os $Q^{q s}, \forall s$ compartinham o mesmo objetivo sensório.

${ }^{7}$ Note apenas os elementos da camada oculta recrutados pelo mecanismo de poda da Seção 4.2.3 são utilizados na formação das classes.
} 
ficação das descontiguidades apresentado na Seção 4.3.

\subsubsection{Treinamento do grafo}

Nesta seção veremos como as variáveis do GSM são modificadas em direção à sua adequação aos comportamentos das entradas sensório-motoras $\mathbf{x}_{t}$ e do seu motivador externo, o objetivo $E_{t}^{*}$.

A estrutura da rede subjacente aos classificadores é treinada conforme descrito na Seção 4.2. Também, os mapas responsáveis pela deteção das descontiguidades são treinados conforme descrito na Seção 4.3, mapas estes responsáveis pela geração dos nós $Q$ e em segunda instância, $\operatorname{dos} \operatorname{arcos} R$ do grafo. Portanto, para estabelecer o treinamento do GSM é preciso definir quais são os motivadores externos a serem utilizados pelos classificadores, ou seja, quais são as amostras que representam as classes a serem buscadas pelos classificadores. Outro ponto importante está em como gerar estes motivadores, visto que eles têm o papel de representar as modificações temporais dos átomos de causalidade, ou seja, têm que engendrar a variação temporal inerente ao átomo para que este possa expressar a relação causa e efeito.

Motivadores externos. Na Seção 3.1, vimos que o átomo de causalidade armazena as situações sensório-motoras que geram sensações contidas em seu objetivo sensório no próximo instante de tempo, como ilustrado na Figura 1. Perceba que a definição das amostras utilizadas para treinar um classificador exige o conhecimento do estado futuro da ativação do seu objetivo. Tendo como premissa o determinismo das relações estabelecidas pelos átomos, ao invés de utilizar o estado futuro, que não se conhece, o estado presente do objetivo é utilizado em combinação com as entradas do instante anterior.

Os motivadores externos dos classificadores, suas classes alvo, serão representados por $\mathbf{e} \in \mathbb{R}^{p}$ de forma que os classificadores associados às saídas y são treinados no 
tempo $t$ com a amostra $\left\{\mathbf{x}_{t} 1, \mathbf{e}_{t}\right\}$. De forma genérica, cada motivador $e_{q}$ capta a variação positiva em um passo de tempo do estado do objetivo associado a $y_{q}$ e é calculado por:

$$
e_{q, t}=\left\{\begin{aligned}
+1 & , \text { se } \mathbf{s}_{t 1} \notin Q_{O, t 1}^{q} \wedge \mathbf{s}_{t} \in Q_{O, t}^{q} ; \quad ; q=1, \ldots, p . \\
1, \text { caso contrário; } &
\end{aligned}\right.
$$

Onde: $Q_{O}^{q}$ é o objetivo associado a $y_{q}$ dado por (4.34) e $\mathbf{s}_{t} \in S$ é tal que $\mathbf{x}_{t}=\left[\mathbf{s}_{t}, \mathbf{a}_{t}\right]$.

Note que segundo a definição dos estados feita na Seção 3.1.3, cada elemento de e indica o conjunto das situações sensório-motoras que faz com que o objetivo de $Q_{k}$ passe do estado não-excitado, em um instante de tempo, para o estado excitado no próximo instante se a $Q_{k}$ for ativado.

Fluxo gerador do treinamento. $\mathrm{O}$ fato da rede utilizada pelo GSM ser treinada pelas amostras $\left\{\mathbf{x}_{t} 1, \mathbf{e}_{t}\right\}$ deixa implícito que é preciso não só armazenar os valores das entradas da rede no instante anterior $\mathbf{x}_{t}{ }_{1}$ mas também os estados de seus fluxos $\mathbf{h}_{t}{ }_{1} \mathrm{e}$ $\mathbf{y}_{t}$ 1. Isto porque eles podem ser necessários ao algoritmo de treinamento ${ }^{8}$. Também, os estados anteriores dos contextos sensórios dos átomos que são utilizados como objetivos $Q_{O, t \quad 1}^{q}$ são utilizados para o cálculo dos motivadores $\mathbf{e}_{t}$. A Figura 11 ilustra o fluxo utilizado para possibilitar o treinamento da rede.

\subsubsection{Considerações sobre o grafo sensório-motor}

Nesta seção são feitas algumas considerações sobre a adequação da implementação do GSM ao modelo teórico do esquema apresentado no Capítulo 3. Em particular, apontaremos como se dão os processos de divisão, fusão, determinação de fronteiras e sugestão de ações.

\footnotetext{
${ }^{8}$ Como por exemplo o algoritmo backpropagation.
} 


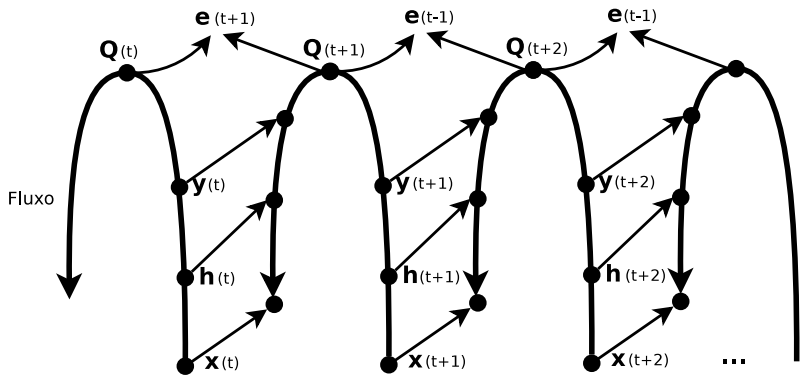

Figura 11: Fluxo gerador do treinamento do grafo sensório-motor. As setas que representam os fluxos em diferentes instantes de tempo, quando ascendentes representam o cálculo dos estados do grafo e quando descendentes representam a aplicação do algoritmo de treinamento. Note que os estados da rede utilizados no treinamento são os estados do instante imediatamente anterior ao atual. Também, o cálculo dos motivadores e são realizados a partir dos estados dos nós do grafo, $Q$, em dois instantes consecutivos de tempo. O objetivo do grafo $E^{*}$ foi omitido na figura.

\subsubsection{Divisão}

O processo de divisão é implementado pelo mecanismo de identificação de descontiguidades da Seção 4.3. Quando um novo subconjunto contíguo é detetado (Seção 4.3.5) e uma nova classe a ele é associada (Seção 4.4.2.1) está ocorrendo o processo de divisão. Note que a divisão se dá dentro de uma mesma classe pela deteção dos seus subconjuntos contíguos, o que é evidenciado pelo fato destes serem utilizados como objetivos para novas classes geradas.

\subsubsection{Fusão}

O processo de fusão entre dois átomos se dá pela deteção do uso dos mesmos elementos da camada oculta com pesos semelhantes por classes distintas.

A deteção da fusão entre duas classes é feita pela averiguação da semelhança entre elas. As classes $Q^{r}$ e $Q^{s}$ são consideradas semelhantes se $W_{r} \simeq W_{s}$, onde $W_{k}$ representa os pesos das conexões da camada oculta à saída $y_{k}$ que gera a classe $Q^{k}$.

Após detetada a semelhança entre as classes $Q^{r}$ e $Q^{s}$, cria-se no grafo o arco $R_{r}^{k i}$ tendo a classe $Q^{r}$ como origem e o subconjunto $Q^{k i}$ como destino se $r<s$ e $\exists R_{s}^{k i}$. Então, a classe $Q^{s}$ e sua saída associada $y_{s}$ são desconectadas do grafo removendo-se 
o $\operatorname{arco} R_{s}^{k i}$. Em outras palavras, o arco $R_{s}^{k i}$ é substituído pelo arco $R_{r}^{k i}$. Note que após a fusão a classe $Q^{r}$ mantém-se como origem de seu antigo arco e passa a também ser o nó de origem para o novo arco $R_{r}^{k i}$. Assim, a ativação da classe $Q^{r}$, dependendo da ação escolhida, pode resultar na ativação de dois subconjuntos distintos. Ou seja, é criada uma bifurcação no grafo.

É importante aqui ressaltar que o processo de fusão tem como principal objetivo evitar o crescimento indefinido do grafo e que, afora este fenômeno, a existência de classes semelhantes não afeta o comportamento do GSM, como exposto na Seção 3.2.6.

\subsubsection{Fronteiras}

O GSM apresentado, por assumir relações causais determinísticas conjuntamente com a suposição de que o espaço sensório-motor de entrada $D$ representa um subconjunto do ambiente externo ao esquema e não sua totalidade ${ }^{9}$, faz com que seja prevista a existência de fronteiras determinísticas. Ou seja, assume-se que certas classes não serão capazes de ser encontradas com base apenas no domínio de entrada, pois o alcance de seus objetivos sensórios $Q_{O}^{k}$ pode depender de estados externos, fora do domínio de entrada.

Na implementação apresentada, as fronteiras determinísticas não precisam ser tratadas de forma especial, pois apenas as classes consideradas estáveis fornecem objetivos para a criação de novas classes, como ressaltado no final da Seção 4.4.2.1.

\footnotetext{
${ }^{9} \mathrm{O}$ contexto do esquema em relação ao seu ambiente externo é a mesma de agentes imersos em ambientes POPDE (Partially Observable Partially Deterministic Environment).
} 


\section{EXPERIMENTOS E RESULTADOS}

Neste capítulo, são expostos os experimentos-chave utilizados para perceber o comportamento dos modelos computacionais propostos neste trabalho.

A Seção 5.1 mostra os principais experimentos realizados para a percepção do funcionamento do mecanismo proposto para a determinação dinâmica e autônoma do número de elementos da camada oculta da RNAFF-1 utilizada como estrutura para os classificadores que representam os contextos sensório-motores dos átomos de causalidade.

A Seção 5.2 mostra os experimentos associados ao processo dinâmico e autônomo utilizado para encontrar os subconjuntos contíguos que compõem as classes encontradas pelo classificador e que implementam o processo de divisão necessário à constituição do grafo sensório-motor.

A Seção 5.3 apresenta os experimentos realizados para a averiguação do funcionamento do grafo sensório-motor que implementa o modelo de esquema cognitivo proposto neste trabalho.

\subsection{Classificador para sistemas baseados em DCAA}

Nesta seção, são descritos dois experimentos que ilustram o comportamento do mecanismo de poda proposto para a determinação dinâmica do número de elementos da camada oculta do classificador detalhado na Seção 4.2. 
O primeiro experimento foi concebido com o propósito de auxiliar o desenvolvimento do modelo computacional proposto, validar seu comportamento perante um problema cujas soluções são conhecidas e também permitir a depuração do código na averiguação de sua conformidade com o modelo proposto. Assim, um problema simples de soluções conhecidas foi utilizado. Já o segundo experimento foi concebido para averiguar o comportamento do mecanismo ao lidar com domínios de maiores dimensões com o objetivo de testar a escalabilidade do domínio de entrada do classificador.

\subsubsection{Experimento 2D-Sphere}

Neste experimento, as amostras apresentadas ao classificador são baseadas em um círculo. Para isso, o domínio de entrada do classificador será dado por $D=[1,+1]^{2} \subset$ $\mathbb{R}^{2}$ e a classe alvo $C$ será dada pela seguinte esfera bi-dimensional centrada na origem:

$$
C=\{x \in D \mid\|x\| \leq \sqrt{2 / \pi}\} .
$$

Note que a área da esfera $C$ tem a metade da área do domínio $D$ de forma que metade dos pontos do domínio pertencem à classe e metade não.

Além do classificador com o mecanismo de poda ( $A A C D$-Class) um classificador idêntico, mas sem o mecanismo de poda (BPN-Class) será utilizado para ressaltar a influência da poda. Como classificador básico será utilizada uma RNAFF-1 treinada com o algoritmo de backpropagation com gradiente descendente e tamanho constante para o passo de treinamento. Ambos os classificadores são treinados com as mesmas amostras nos mesmos passos de treinamento, amostras estas geradas aleatoriamente com distribuição uniforme no domínio $D$.

A Tabela 3 mostra os resultados obtidos. Dois pontos podem ser notados:

1. Ambos classificadores alcançam erros aceitáveis e, apesar da acurácia do classificador $A A C D$-Class não ser tão boa quanto a do $B P N$-Class, o número final de 


\begin{tabular}{|c|c|c|c|c|c|c|c|c|c|}
\hline \multirow{2}{*}{ Exp } & \multirow{2}{*}{ \# exec } & \multirow{2}{*}{$\begin{array}{l}\text { \# init } \\
\text { oculto }\end{array}$} & \multirow{2}{*}{ Classif } & \multicolumn{2}{|c|}{ \# final oculto } & \multicolumn{2}{|c|}{ Erro } & \multicolumn{2}{|c|}{ Erro poda } \\
\hline & & & & Mean & StdDev & Mean & StdDev & Mean & StdDev \\
\hline \multirow{2}{*}{ Exp-1A } & \multirow{2}{*}{$1 \times 10^{6}$} & \multirow{2}{*}{6} & BPN & 6.00 & 0.0000 & 0.0260 & 0.0110 & - & - \\
\hline & & & AACD & 3.66 & 0.7902 & 0.0510 & 0.0600 & 0.0511 & 0.0599 \\
\hline \multirow{2}{*}{ Exp-1B } & \multirow{2}{*}{$2 \times 10^{6}$} & \multirow{2}{*}{20} & BPN & 20.00 & 0.0000 & 0.0094 & 0.0044 & - & - \\
\hline & & & AACD & 5.54 & 1.2524 & 0.0223 & 0.0120 & 0.0234 & 0.0158 \\
\hline \multirow{2}{*}{ Exp-1C } & \multirow{2}{*}{$2 \times 10^{6}$} & \multirow{2}{*}{100} & BPN & 100.00 & 0.0000 & 0.0067 & 0.0031 & - & - \\
\hline & & & AACD & 5.46 & 0.6696 & 0.0162 & 0.0063 & 0.0162 & 0.0063 \\
\hline
\end{tabular}

Tabela 3: Exp-1. Resultados para 50 execuções distintas tendo uma esfera bi-dimensional como classe alvo com os parâmetros: $k=2.0 ; s=0.002 ;{ }_{v}=5 \times 10^{6} ;{ }_{w}(0)=0.01$; $\beta=0.0001 ; \tau=1.2$.

elementos na camada oculta nunca excede 6 , mesmo quando a rede é iniciada com 100 elementos $(\operatorname{Exp}-1 C)^{1}$;

2. Os erros do classificador $A A C D$-Class com ou sem poda são praticamente os mesmos, permitindo concluir que os elementos ocultos removidos pela poda não estavam mais contribuindo para a constituição da classe.

O comportamento dos pesos $\mathbf{w}$ associados aos elementos da camada oculta desempenham papel central no mecanismo de poda proposto. Para uma melhor compreensão das dinâmicas dos pesos $w_{j}$ quando da aplicação do mecanismo de poda utilizaremos três formas de visualizar graficamente seus comportamentos. Na primeira, os valores de $\left|w_{j}(t)\right|$ são sobrepostos no mesmo gráfico para todos os elementos $j$ e para todas as 50 execuções. O gráfico resultante nos permite perceber se há caminhos seguidos pelos pesos e caso haja, quais são. Outra visualização diz respeito não mais à evolução dos valores dos pesos durante cada execução, mas aos valores que estes pesos assumem no final de cada execução, ou seja, um gráfico de $w_{j}(T) \times \operatorname{Exec}_{n}$, onde $T$ é número máximo de iterações de cada execução e $E_{x e c}$ é a $n$-ésima execução. Esta visualização permite percebermos se há ou não padrões nos valores alcançados pelos pesos quando da convergência dos classificadores. A terceira visualização utilizada é o histograma dos valores dos pesos no final de cada execução $w_{j}(T)$ que em conjunto com visualização anterior nos permite perceber a importância dos possíveis padrões encontrados naquela.

\footnotetext{
${ }^{1}$ Note que o baixo número de elementos encontrados pelo $A A C D$-Class está relacionado com sua baixa acurácia e que dependem dos parâmetros utilizados pelo algoritmo de poda.
} 
A seguir, os gráficos que representam as três formas de visualização das dinâmicas dos pesos w são apresentadas para cada um dos três experimentos da Tabela 3 juntamente com os gráficos dos erros de classificação com e sem o mecanismo de poda.

A Figura 12 mostra os gráficos utilizados para a percepção das dinâmicas dos pesos obtidas no experimento Exp-1A.

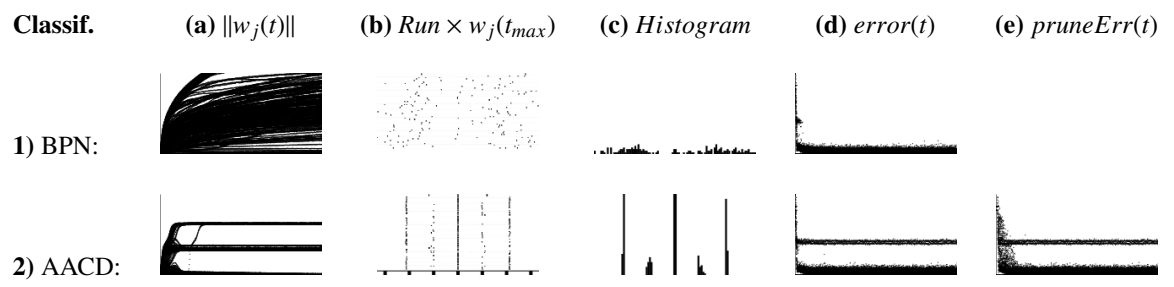

Figura 12: Exp-1A. Dinâmicas dos pesos da camada oculta $w_{j}$ e erros dos classificadores obtidos por 50 execuções distintas com $10^{6}$ iterações utilizando classificadores com 2 entradas e camada oculta iniciada com 6 elementos. São mostrados 4 gráficos para o classificador $B P N$ Class e 5 para o AACD-Class, pois o mecanismo de poda não é aplicado ao primeiro. Os gráficos 1a e 2a mostram a sobreposição dos valores de $\left|w_{j}\right|$ ao longo das iteração para todas as 50 execuções. Os gráficos $\mathbf{1 b}$ e $\mathbf{2 b}$ mostram os valores de $w_{j}$ (eixo $x$ ) ao final de cada execução (eixo $y$ ), o gráfico $\mathbf{2 b}$ também marca os valores dos atratores $a_{k}$ utilizados pelo mecanismo de poda. Os gráficos 1c e 2c mostram o histograma dos valores de $w_{j}$ utilizando 100 categorias uniformemente distribuídas no intervalo [ 4.0,+4.0]; $y$ varia entre 0 e 50. Os gráficos $1 \mathbf{d}$ e 2d mostram as sobreposições dos erros dos classificadores sem poda para as 50 execuções; o erro varia entre 0.0 e 0.6 . O gráfico 2 e mostra as sobreposições dos erros apresentados pelo classificador $A A C D$-Class não utilizando os elementos indicados pelo mecanismo de poda, ou seja, os elementos cujo peso associado $w_{j}$ pertenciam à bacia $B_{0}$; assim como em $\mathbf{2 d}$ o erro varia entre 0.0 e 0.6 .

Na Figura 12, pelos gráficos $(1 a),(1 b)$ e (1c) pode-se perceber que para o classificador $B P N$-Class os pesos $w_{j}$ se distribuem pelo intervalo notado. Também, percebe-se por $(1 b)$ e (1c) uma leve aglomeração em dois valores simétricos. Por outro lado, por $(2 a),(2 b)$ e $(2 c)$ pode-se notar que os pesos $w_{j}$ do classificador $A A C D$-Class convergem para seus atratores. Um outro ponto é que $A A C D$-Class não obteve um bom desempenho em todas as execuções, mas nas vezes em que o teve os erros são comparáveis aos de obtidos pelo $B P N$-Class. Por último, por $(2 d)$ e $(2 e)$ percebe-se que a aplicação da poda não modificou o desempenho do $A A C D$-Class, evidenciando que foram podados elementos que já não estavam participando da constituição da classe.

A Figura 13 mostra os gráficos utilizados para a percepção das dinâmicas dos pesos 
obtidas no experimento Exp-1B.

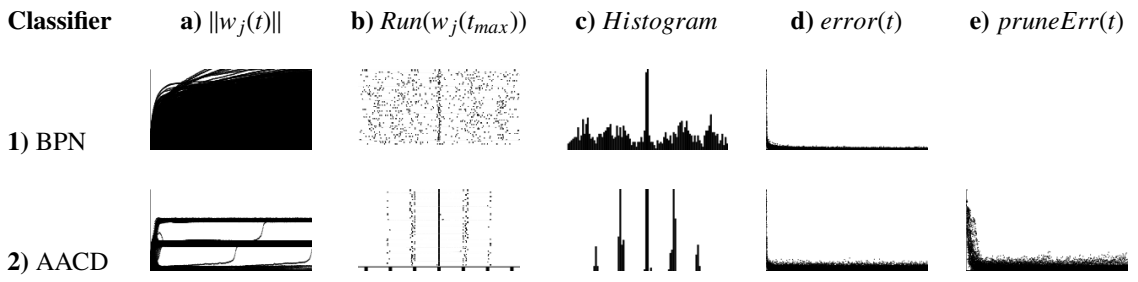

Figura 13: Exp-1B. Dinâmicas dos pesos da camada oculta $w_{j}$ e erros dos classificadores obtidos por 50 execuções distintas com $2 \times 10^{6}$ iterações utilizando classificadores com 2 entradas e camada oculta iniciada com $\mathbf{2 0}$ elementos.

Na Figura 13, pelos gráficos $(1 a),(1 b)$ e (1c) pode-se notar que os pesos do classificador $B P N$-Class tendem a se concentrarem em 5 regiões. Aos mesmo tempo, pelos gráficos $(2 a),(2 b)$ e $(2 c)$ pode-se perceber que os pesos de $A A C D$-Class mantém a convergência para seus atratores. Também, nota-se que os erros obtidos pela versão com poda do $A A C D$-Class se mantêm maiores do que os de sua versão sem poda, que por sua vez se mantêm maiores do que os obtidos pelo BPN-Class. Porém, é importante ressaltar que para este experimento Exp-1B, como mostra a Tabela 3, a versão com poda utiliza em média apenas 5.54 dos 20 elementos disponíveis na camada oculta e que todos estes 20 elementos são utilizados pelo BPN-Class.

A Figura 14 mostra os gráficos utilizados para a percepção das dinâmicas dos pesos obtidas no experimento Exp-1C.

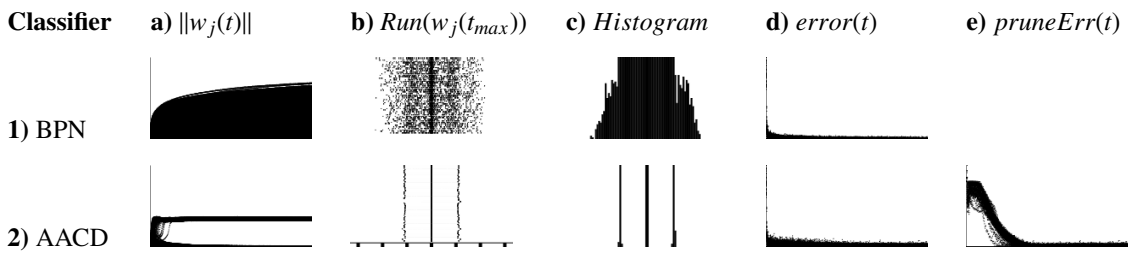

Figura 14: Exp-1C. Dinâmicas dos pesos da camada oculta $w_{j}$ e erros dos classificadores obtidos por 50 execuções distintas com $2 \times 10^{6}$ iterações utilizando classificadores com 2 entradas e camada oculta iniciada com 100 elementos.

Na Figura 14, pelo gráfico ( $1 b$ ) pode-se notar que os pesos do classificador $B P N$ Class tendem a se concentrarem em 3 regiões. Também, pelos gráficos $(2 a),(2 b)$ e 
(2c) nota-se que os pesos de $A A C D$-Class continuam a convergir para seus atratores, mas agora convergem para apenas 3 atratores. Neste experimento nota-se que os erros da versão com poda graficados em (2e) não convergem tão rapidamente quando o das outras versões, mas alcançam sempre valores comparáveis. Neste experimento Exp-1C é importante notar que a versão com poda está utilizando em média apenas 5.46 dos 100 elementos disponíveis na camada oculta.

\subsubsection{Experimento 10D-Sphere}

Este experimento tem como propósito averiguar o comportamento do classificador com o mecanismo de poda em domínios com dimensões maiores. Para se ter o experimento $2 D$-Sphere como parâmetro a classe alvo será mantida como uma esfera, porém agora 10-dimensional. Assim, o domínio de entrada será dado por $D_{10}=[1,+1]^{10} \subset \mathbb{R}^{10}$ com a classe alvo $C_{10}$ dada por:

$$
C_{10}=\left\{x \in D_{10} \mid\|x\| \leq r_{10}\right\},
$$

onde $r_{10}=1.6993$ será utilizado como o raio gerando uma esfera com um volume de aproximadamente 512.0. Note que apesar do volume da esfera representar metade do volume do domínio $\left(2^{10}=1024\right)$ a classe alvo $C_{10}$ representa aproximadamente apenas 0.35 do volume do domínio, isto porque a classe é a interseção entre o domínio e a hiper-esfera, (note que $r_{10}>1$ ). Para que os resultados sejam comparáveis ao experimento $2 D$-Sphere o código de amostragem da classe foi modificado para que a probabilidade de gerar pontos da classe e da não-classe fossem de 0.5 .

Assim como no experimento $2 D$-Sphere, três variações modificando apenas o número inicial de elementos da camada oculta foram realizados. Os resultados são mostrados na Tabela 4.

Nos três experimentos o mecanismo de poda resultou na manutenção de 12 a 15 elementos na camada oculta. O fato dos erros apresentados pela versão $A A C D$-Class 


\begin{tabular}{|c|c|c|c|c|c|c|c|c|}
\hline \multirow{2}{*}{ Exp } & \multirow{2}{*}{$\begin{array}{l}\text { \# init } \\
\text { oculto }\end{array}$} & \multirow{2}{*}{ Classif } & \multicolumn{2}{|c|}{ \# final oculto } & \multicolumn{2}{|c|}{ Erro } & \multicolumn{2}{|c|}{ Erro poda } \\
\hline & & & Mean & StdDev & Mean & StdDev & Mean & StdDev \\
\hline \multirow{2}{*}{ Exp-2A } & \multirow{2}{*}{20} & BPN & 20.00 & 0.0000 & 0.0627 & 0.0124 & - & - \\
\hline & & AACD & 13.28 & 1.0008 & 0.0973 & 0.0101 & 0.1040 & 0.0259 \\
\hline \multirow{2}{*}{ Exp-2B } & \multirow{2}{*}{100} & BPN & 100.00 & 0.0000 & 0.0284 & 0.0070 & - & - \\
\hline & & AACD & 13.76 & 0.9708 & 0.1021 & 0.0190 & 0.1039 & 0.0204 \\
\hline \multirow{2}{*}{ Exp-2C } & \multirow{2}{*}{200} & BPN & 200.00 & 0.0000 & 0.0369 & 0.0086 & - & - \\
\hline & & AACD & 14.16 & 1.0072 & 0.0984 & 0.0128 & 0.1000 & 0.0137 \\
\hline
\end{tabular}

Tabela 4: Exp-2. Resultados para 50 execuções distintas tendo uma hiper-esfera 10dimensional como classe alvo com os parâmetros: $k=2.0 ; s=0.002 ;{ }_{w}(0)=0.01$; $\beta=0.0001 ; \tau=1.2$. Para Exp-2A usou-se ${ }_{v}=5 \times 10^{6}$ e $T=4 \times 10^{6}$ iterações foram realizadas em cada execução. Para Exp-2B e Exp-2C usou-se $\quad v=2 \times 10^{5} \operatorname{com} T=5 \times 10^{6}$.

serem em torno de 3 vezes maiores do que os da versão $B P N$-Class tem em contrapartida a capacidade de manutenção do número de elementos utilizados, independentemente do número inicial de elementos.

A Figura 15 mostra os gráficos utilizados para a percepção das dinâmicas dos pesos obtidas no experimento Exp-2C.

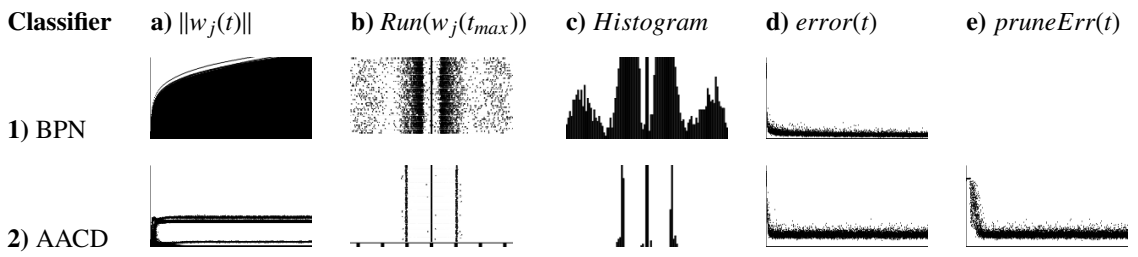

Figura 15: Exp-2C. Dinâmicas dos pesos da camada oculta $w_{j}$ e erros dos classificadores obtidos por 50 execuções distintas com $5 \times 10^{6}$ iterações utilizando classificadores com 10 entradas e camada oculta iniciada com 200 elementos.

Na Figura 15, pelos gráficos (1b) e (1c) pode-se notar que os pesos do classificador $B P N$-Class tendem a valores que geram um padrão. Também, nota-se pelos gráficos $(2 a),(2 b)$ e $(2 c)$ que os pesos de $A A C D$-Class continuam convergindo para seus atratores.

\subsection{Mecanismo de identificação de descontiguidades}

Nesta seção, mostraremos alguns experimentos realizados para exaltar o comportarmento do mecanismo proposto para a identificação de subconjuntos não contíguos 
e que também foram utilizado para testar e validar o mecanismo.

Os experimentos estão divididos em duas categorias principais. Primeiramente veremos 4 experimentos demonstrativos construídos para exercitar a capacidade do mapa em se manter coerente com a RNAFF-1 mesmo em situações de modificações abruptas de sua estrutura, e também para ressaltar a sensibilidade do mapa na separação de subconjuntos quase discontiguos (com região pequena estabelecendo a conexão). Em seguida é mostrado a aplicação do mecanismo em dois problemas de classificação utilizando dados empíricos obtidos do UCI Machine Learning Repository (LICHMAN, 2013).

\subsubsection{Experimentos demonstrativos}

Nesta categoria de experimentos são utilizados domínios em $\mathbb{R}^{2}$ para que seja possível visualizar graficamente as classes encontradas pelo classificador.

\subsubsection{Modificação da estrutura do classificador}

A capacidade do mecanismo em se manter coerente com a estrutura da rede subjacente ao classificador mesmo em situações de mudanças abruptas é aqui mostrada por dois experimentos.

Nestes experimentos a classe alvo utilizada para treinar os classificadores é trocada durante o treinamento.

No primeiro experimento uma esfera com centro $c=(0,0)$ e raio $r=0.6$ é utilizada como classe alvo para os primeiros 60.000 passos de tempo. Note que a classe alvo é utilizada para gerar as amostras que são utilizadas para treinar o classificador. Então, no passo 60.001 a classe alvo é abruptamente modicada para duas esferas centradas em $c_{1}=(+0.5,+0.4)$ e $c_{2}=(0.4,0.4)$ com raios $r_{1}=0.3$ e $r_{2}=0.3$. Para este experimento o classificador é implementado por um RNAFF-1 com 6 elementos na 
camada oculta utilizado uma implementação padrão do algoritmo backpropagation para seu treinamento. A Figura 16 mostra os resultados deste experimento.

(a1)

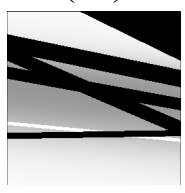

$t=t_{1}$ (a2)

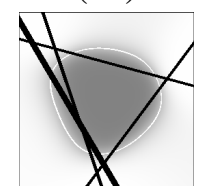

$t=t_{2}$ (a3)

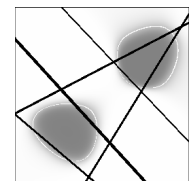

$t=t_{3}$ (a4)

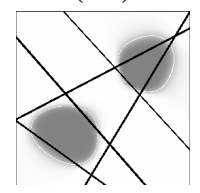

$t=t_{4}$ (b1)

Figura 16: Adaptação à modificação da estrutura da RNAFF-1 do classificador. As imagens (a) mostram as classificações do domínio de entrada alcançada pelo classificador nos instantes de tempo: $t_{1}=30,000, t_{2}=60,000, t_{3}=210,000, t_{4}=360,000$. As regiões escuras representam classificações positivas $(y(x)>0)$ e as claras, negativas $(y(x)<0)$. As regiões nas quais algum elemento da camada oculta da rede tem sua saída zerada $\left(h_{j}(x)=0\right)$ são pintadas em preto. Os gráficos das figuras (b) apresentam a evolução no tempo das seguintes métricas: (b1) erro do classificador, em [0,1]; (b2) energia do mapa, em [0,1]; (b3) menor energia dentre os elementos do mapa, em [0,1]; (b4) menor valor absoluto dentre todas as coordenadas dos elementos, em [0,1]; (b5) número de subconjuntos convexos encontrados, em [0,16]; (b6) número de subconjuntos contíguos detetados, em $[0,4]$. Todos os gráficos possuem 4 marcas no eixo $x$ sinalizando os instantes de tempo $t_{1}, t_{2}, t_{3}, t_{4}$. Note que (a2) mostra a classe delineada pelo classificador no momento imediatamente anterior à mudança da classe alvo de 1 para 2 esferas e que (a4) mostra o resultado da classificação para 2 esferas.

No segundo experimento as classes alvo utilizadas são o conjunto complementar das classes do primeiro experimento, com relação ao domínio de entrada $D=$ $[1,+1]^{2}$. O mesmo classificador do experimento anterior com 6 elementos na camada oculta é utilizado neste experimento. Os resultados são mostrados na Figura 17. Este segundo experimento foi concebido para averiguar o comportamento do mecanismo quando a classe alvo é composta por vários subconjuntos convexos formando um único conjunto contíguo. Note que ambas as classes são côncavas. Na Figura 17, perceba o crescimento do número de subconjuntos convexos em (b5) ao mesmo tempo em que (b6) mostra que há a manutenção da deteção de um único subconjunto contíguo mesmo depois da modificação da classe alvo em $t_{2}$. Perceba também a instabilidade da energia do mapa mostrada pelos pulsos em (b2). 


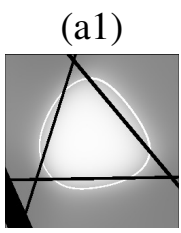

$t=t_{1}$

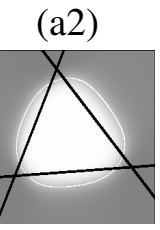

$t=t_{2}$ (a3)

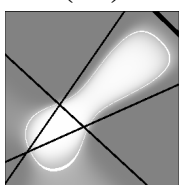

$t=t_{3}$ (a4)

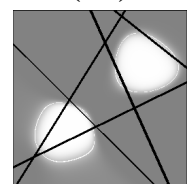

$t=t_{4}$ (b1)

(b6)
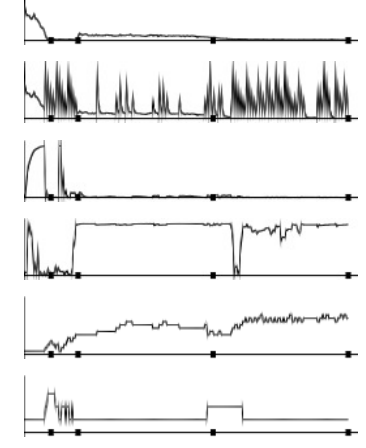

Figura 17: Experimento com mudança abrupta da classe alvo utilizando o complemento em $D=[1,+1]^{2}$ das classes utilizadas no primeiro experimento.

\subsubsection{Critérios para contiguidade}

Os próximos dois experimentos foram concebidos para ressaltar a influências dos parâmetros $L_{d}$ e $L_{s}$ em como o mecanismo considera a contiguidade entre os subconjuntos. Os subconjuntos podem ser conectados por regiões pequenas e pouco visitadas. O critério de quando considerar ou não estas regiões como conexões entre subconjuntos é estabelecido por estes parâmetros.

Os parâmetros $L_{s}$ e $L_{d}$ determinam o quão próximas duas regiões devem estar para serem consideradas contíguas. Para evidenciar a influência destes parâmetros, serão utilizados 2 experimentos idênticos utilizando a mesma classe alvo, sendo a única diferença entre eles, os valores estabelecidos para $L_{s}$ e $L_{d}$. No primeiro experimento da Figura 18, o mecanismo detetou que a classe é composta por dois subconjuntos contíguos, enquanto no segundo experimento da Figura 19 a classe foi tida como sendo composta por um único subconjunto contíguo. Ambos os experimentos utilizam um classificador com 2 elementos na camada oculta.

O experimento da Figura 18 utiliza um alto valor para $L_{s}$ permitindo pequenas regiões de interseção (baixa frequência de ativação) compartilharem o mesmo elemento do mapa com regiões vizinhas com maior frequência de ativação fazendo com que essa 


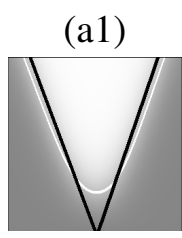

$t=t_{1}$

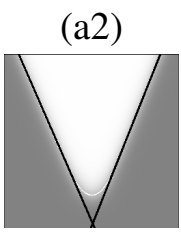

$t=t_{2}$

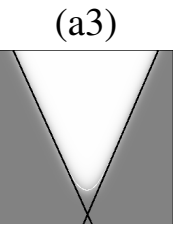

$t=t_{3}$

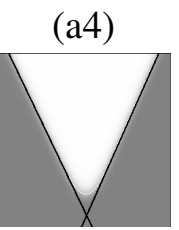

$t=t_{4}$ (b1)

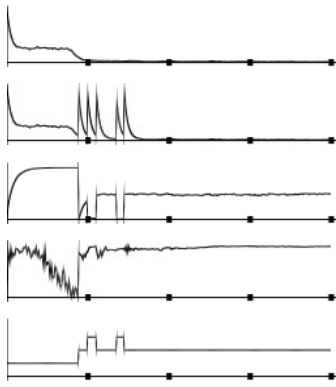

(b6)

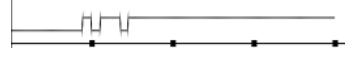

Figura 18: Uma classe contígua conectada por uma pequena região é tida pelo mecanismo como composta por dois subconjuntos contíguos ao se utilizar: $L_{d}=0.05$ (limite de menor energia dos elementos) e $L_{s}=0.1$ (limite de instabilidade dos elementos). Os tempo são marcados em: $t_{1}=2,5000 ; t_{2}=50,000 ; t_{3}=75,000 ; t_{4}=100,000$. Os gráficos (b5) e (b6) variam de 0 a 4 . Note que (b5) mostra apenas dois subconjuntos convexos. A pequena região conectando os dois subconjuntos não é capturada pelo mapa e, portanto, (b6) converge para 2 subconjuntos contíguos.

região não seja percebida como uma região separada. Também, um alto valor de $L_{d}$ faz com que apenas elementos com alta frequência de ativação sejam mantidos no mapa. Como resultado, raramente se cria elementos para regiões pequenas e também estes elementos são mais facilmente removidos do mapa.

\subsubsection{Experimentos com dados empíricos}

Esta seção mostra a performance do mecanismo proposto ao serem utilizados 2 conjuntos de dados conhecidos disponibilizados por UCI Machine Learning Repository (LICHMAN, 2013).

Um ponto importante a ser notado é que o conjunto de amostras é conhecido de antemão. Para adaptar a utilização destas amostras à forma de stream esperada pelo classificador proposto foi criado um mecanismo aleatório de reamostragem. O classificador passa então a ter acesso apenas à amostra corrente e não é utilizada nenhuma outra informação acerca do conjunto de amostras como um todo.

Todas as amostras são utilizadas para o treinamento, ou seja, não há separação 


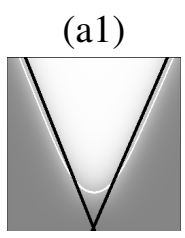

$t=t_{1}$

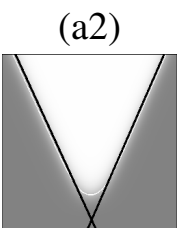

$t=t_{2}$

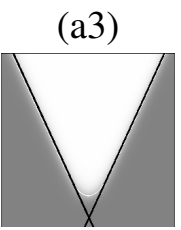

$t=t_{3}$

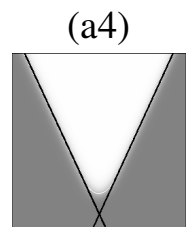

$t=t_{4}$ (b1)

(b3)

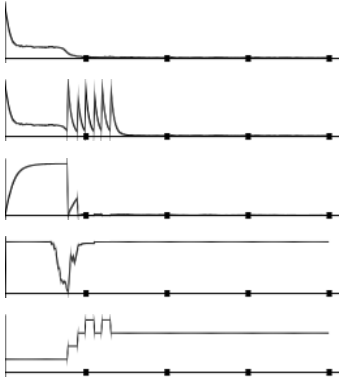

(b6)

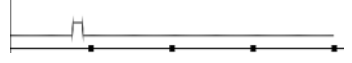

Figura 19: Uma classe contígua conectada por uma pequena região é tida pelo mecanismo como composta por apenas um subconjunto contíguo ao se utilizar: $L_{d}=0.001$ (limite de menor energia dos elementos) e $L_{s}=0.001$ (limite de instabilidade dos elementos). Note que (b5) mostra 3 subconjuntos convexos mostrando que a pequena região que conecta os dois subconjuntos é capturada e mantida no mapa. Como consequência (b6) converge para apenas um subconjunto contíguo.

em conjuntos de treino, teste e avaliação. Isto porque aqui não estamos interessados em encontrar métricas para inferir a capacidade do classificador em encontrar a classe alvo, mas sim com a capacidade do mecanismo em encontrar estruturas que reflitam as descontiguidades da classe.

Todas as variáveis de entrada (atributos) são normalizadas para a faixa $[1,+1]$ respeitando seus domínios originais específicos. Para cada experimento a média e o desvio padrão foram calculados sobre 10 execuções para todas as 6 métricas, Figura 16, utilizadas. Em todos os experimentos os parâmetros do mecanismo foram configurados com os valores: $L_{e}=0.15, L_{s}=0.2, L_{m}=0.5$ e $L_{d}=0.001$.

\subsubsection{Dados sobre câncer de mama}

Este conjunto de dados tem 683 amostras com 9 atributos (variáveis de entrada) e 2 classes de saída. A Tabela 5 mostra os resultados deste experimento. Note que a MapEnergy convergiu para o Error do classificador e apesar da existência de elementos instáveis $\left(\right.$ E.Value $\left.<L_{s}\right)$ a menor energia dos elemetos E.Energy está abaixo do limite de maturidade $L_{m}$. Este experimento mostra que a classe pode ser represen- 


\begin{tabular}{|c|c|c|c|c|c|c|c|c|c|c|c|c|}
\hline Class & \multicolumn{2}{|c|}{ Error } & \multicolumn{2}{|c|}{ MapEnergy } & \multicolumn{2}{c|}{ E.Energy } & \multicolumn{2}{c|}{ E.Value } & \multicolumn{2}{|c|}{ N.Convex } & \multicolumn{2}{c|}{ N.Contig } \\
\hline & $\mathrm{M}$ & $\mathrm{SD}$ & $\mathrm{M}$ & $\mathrm{SD}$ & $\mathrm{M}$ & $\mathrm{SD}$ & $\mathrm{M}$ & $\mathrm{SD}$ & $\mathrm{M}$ & $\mathrm{SD}$ & $\mathrm{M}$ & $\mathrm{SD}$ \\
\hline 0 & 0.02 & 0.00 & 0.02 & 0.01 & 0.47 & 0.26 & 0.7 & 0.3 & 4.1 & 1.3 & 1.0 & 0.0 \\
\hline
\end{tabular}

Tabela 5: Resultados do experimento com a base de dados BreastCancer utilizando uma RNAFF-1 com 5 elementos na camada oculta.

tada por apenas 4 subconjuntos convexos que formam um único conjunto contíguo que representa a classe.

\subsubsection{Dados sobre blocos em páginas}

Este conjunto de dados tem 5473 amostras com 10 atributos (variáveis de entrada) e 5 classes de saída. A Tabela 6 mostra os resultados para 5 experimentos, um para cada classe de saída. Pela Tabela 6 pode-se perceber que nos experimentos para as

\begin{tabular}{|c|c|c|c|c|c|c|c|c|c|c|c|c|}
\hline Class & \multicolumn{2}{|c|}{ Error } & \multicolumn{2}{c|}{ MapEnergy } & \multicolumn{2}{c|}{ E.Energy } & \multicolumn{2}{c|}{ E.Value } & \multicolumn{2}{c|}{ N.Convex } & \multicolumn{2}{c|}{ N.Contig } \\
\hline & $\mathrm{M}$ & $\mathrm{SD}$ & $\mathrm{M}$ & $\mathrm{SD}$ & $\mathrm{M}$ & $\mathrm{SD}$ & $\mathrm{M}$ & $\mathrm{SD}$ & $\mathrm{M}$ & $\mathrm{SD}$ & $\mathrm{M}$ & $\mathrm{SD}$ \\
\hline 0 & 0.05 & 0.01 & 0.14 & 0.25 & 0.03 & 0.04 & 0.5 & 0.3 & 8.3 & 1.7 & 1.0 & 0.0 \\
\hline 1 & 0.02 & 0.00 & 0.02 & 0.00 & 0.06 & 0.07 & 0.4 & 0.3 & 6.2 & 3.3 & 1.0 & 0.0 \\
\hline 2 & 0.00 & 0.00 & 0.00 & 0.00 & 0.25 & 0.03 & 0.1 & 0.1 & 1.0 & 0.0 & 1.0 & 0.0 \\
\hline 3 & 0.01 & 0.00 & 0.01 & 0.00 & 0.01 & 0.02 & 0.2 & 0.2 & 3.4 & 0.9 & 2.0 & 0.4 \\
\hline 4 & 0.02 & 0.00 & 0.02 & 0.00 & 0.07 & 0.14 & 0.2 & 0.2 & 4.8 & 2.1 & 1.7 & 0.5 \\
\hline
\end{tabular}

Tabela 6: Resultados dos experimentos para o conjunto de dados PageBlock.

classes 3 e 4 o número de subconjuntos contíguos encontrados foi, em média, 2.0 e 1.7 indicando que as classes encontradas pelo classificador podem ser representadas por 2 subconjuntos não contíguos no espaço de entrada.

\subsection{Experimento para o grafo sensório-motor}

A complexidade das estruturas geradas pelo desenvolvimento da rede neural que implementa o grafo proposto se apresenta como uma barreira, tanto para a averiguação da coerência do modelo com o comportamento que dele se espera, quanto para a validação do próprio código computacional. A principal dificuldade está na validação dos contextos sensório-motores representados pelos nós do grafo. Outra dificuldade está 
em perceber as influências que os elementos da camada oculta da rede neural têm na constituição dos contextos sensório-motores.

Por estes motivos, neste experimento, optou-se por utilizar um agente com um único sensor e um único atuador. Também, o agente possui um único esquema (grafo sensório-motor) conectado ao sensor e ao atuador do agente. Desta forma, os contextos sensório-motores encontrados pelo grafo podem ser visualizados como imagens bidimensionais.

A Figura 20 ilustra o ambiente no qual o agente está inserido. $\mathrm{O}$ agente possui um

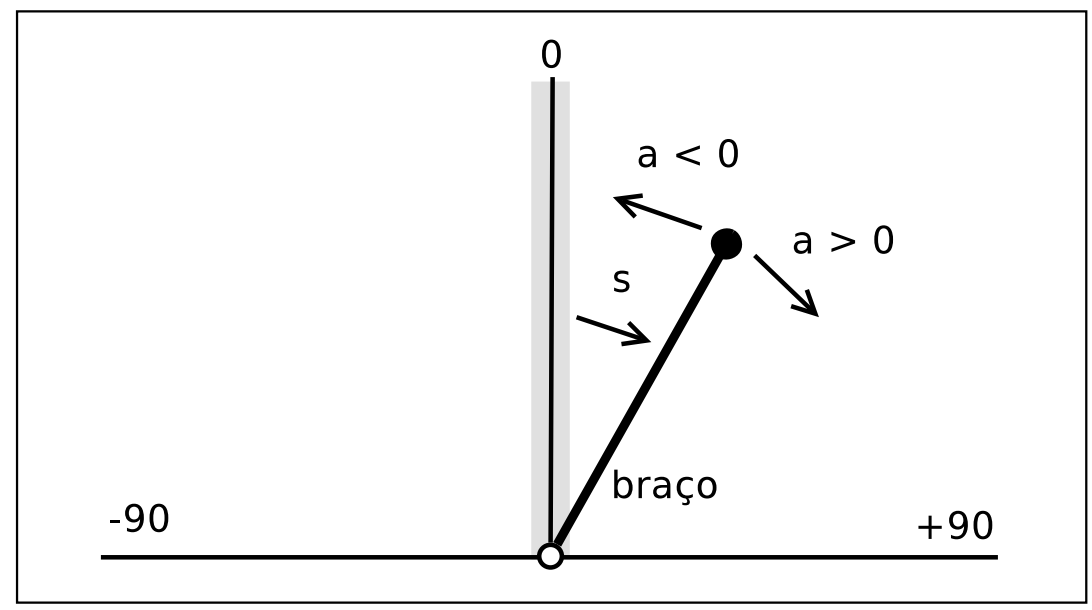

Figura 20: Ambiente utilizado no experimento. O agente possui um único braço que pode ser movido no sentido horário, com valores positivos do atuador $(a>0)$, ou no sentido antihorário, com valores negativos do atuador $(a<0)$. O sensor do agente indica a posição angular do braço em relação à vertical, normalizada para $[1,+1]$. O movimento angular do braço pode variar de $90 \mathrm{a}+90$ graus. A região em cinza indica o objetivo do agente.

único braço e sua percepção do ambiente se dá por um único sensor que lhe permite saber o ângulo que seu braço faz com a posição vertical. $\mathrm{O}$ atuador do agente modifica a posição angular do braço. O objetivo do único esquema do agente é o de posicionar o braço na posição vertical, ou seja, fazer com que seu sensor esteja próximo de zero.

A Figura 21 mostra a interface utilizada pela implementação do experimento. No canto superior esquerdo é visualizado o ambiente no qual o agente está inserido. Logo abaixo são visualizados os valores dos pesos das conexões entre a camada oculta e a 
de saída e a função de penalização utiliza pelo mecanismo de poda. A imagem inferior mostra a camada de saída da rede subjacente ao GSM com os elementos da camada oculta e da camada de saída da rede neural e também os pesos das conexçoes entre elas. No canto superior direito são mostrados os contextos sensório-motores do classificador associado ao objetivo do esquema (o primeiro elemento da saída da rede). A imagem da direita mostra o contexto gerado pela rede com a aplicação do mecanismo de poda e da esquerda, sem este mecanismo.

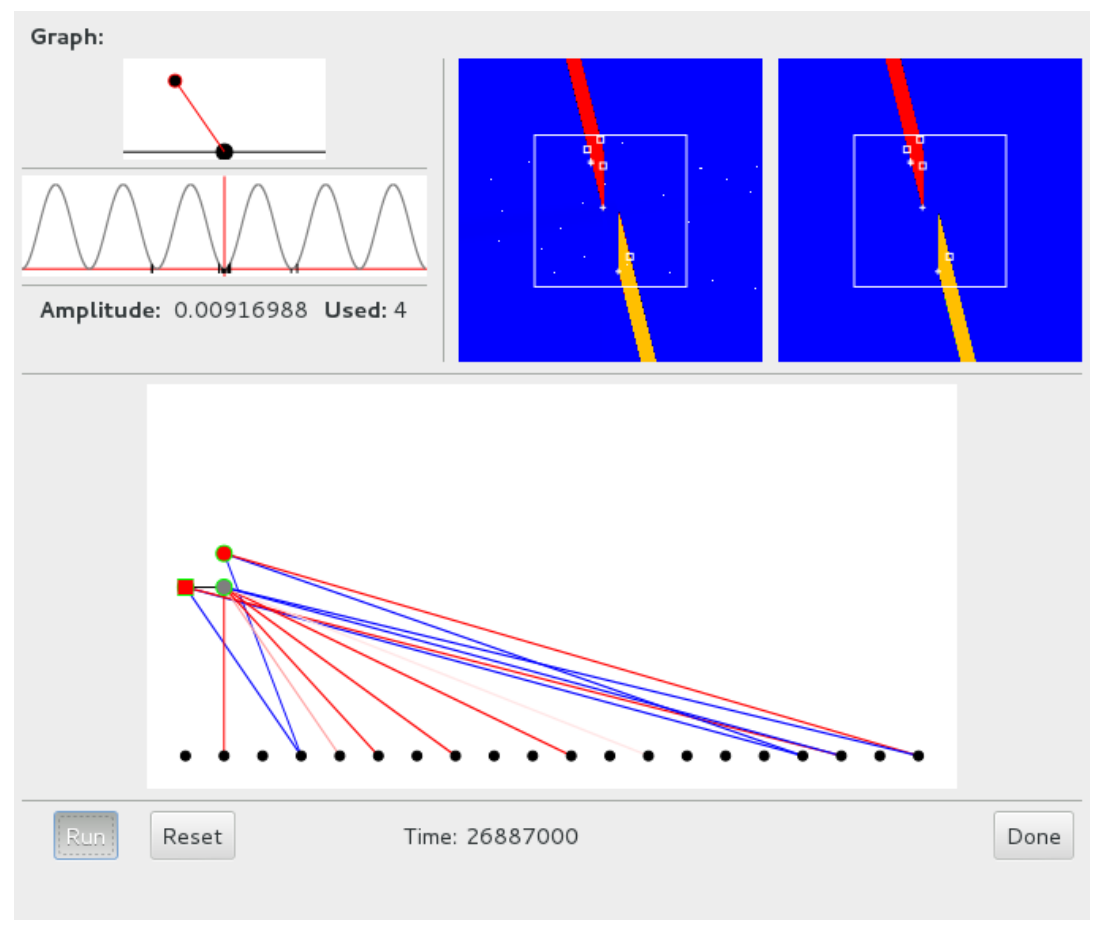

Figura 21: Interface do aplicativo utilizado para testar o GSM.

A Figura 22 mostra a camada oculta e a de saída da rede neural que implementa o grafo encontrado pelo experimento. A rede possui três elementos na camada oculta: $Q^{1}, Q^{2}, Q^{3}$, da esquerda para a direita. Cada $Q^{k}$ possui 2 subelementos, $Q^{k 1}$ e $Q^{k 2}$, que representam os nós do grafo. O elemento $Q^{1}$ indica o contexto sensório-motor que se conecta ao objetivo do esquema, não mostrado na figura. Note que os nós de $Q^{2}$ estão conectados a $Q^{11}$ e que os nós de $Q^{3}$ estão conectados a $Q^{12}$.

Para melhor entender o grafo, na Figura 23 são mostrados os conjuntos que for- 


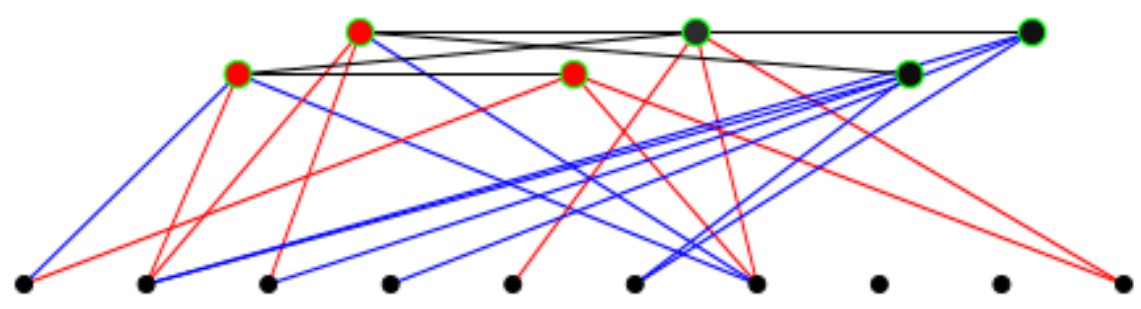

Figura 22: Grafo sensório-motor resultante. O objetivo não está sendo mostrado.

mam os contextos sensório-motores de seus nós, $Q^{k i}$. Os dois nós de $Q^{1}$ mostram quais situações sensório-motoras, $[s, a]$, levam à obtenção de sensações que pertencem ao objetivo do grafo no instante seguinte. Da mesma forma, $Q^{2}$ indica como se pode atingir sensações que pertençam ao contexto sensório ${ }^{2}$ de $Q^{11}$, e $Q^{3}$ indica como chegar a $Q^{12}$.

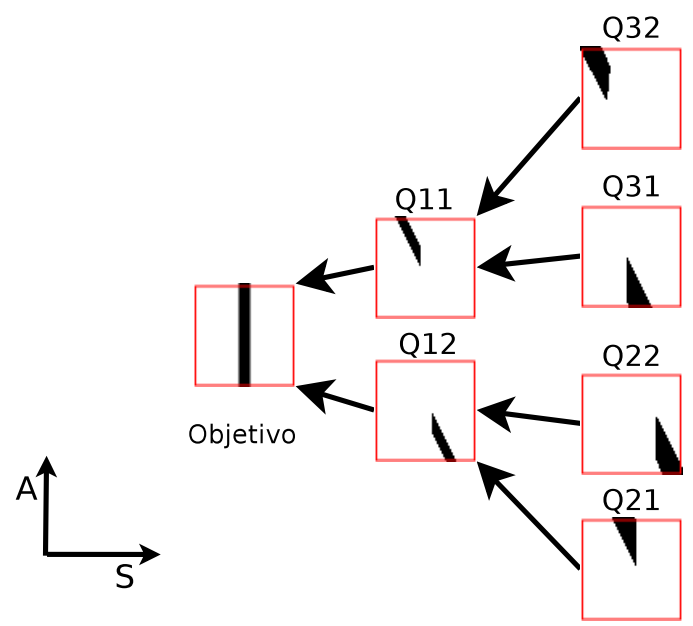

Figura 23: Grafo sensório-motor com a visualização dos contextos sensório-motores de seus átomos de causalidade.

Note que se a sensação corrente do agente pertencer ao contexto sensório de qualquer nó do grafo, este é capaz de prever os caminhos que podem ser utilizados para atingir o objetivo. Note também que a união dos contextos sensórios de todos os nós do grafo abrange todo o domínio sensório do agente. Como consequência, em todas as

\footnotetext{
${ }^{2} \mathrm{O}$ contexto sensório de $Q^{k} i$ é dado por sua projeção no espaço sensório $S$.
} 
situações o grafo mostra as sequências de ações que levam à obtenção do objetivo. 


\section{CONCLUSÕES E TRABALHOS FUTUROS}

Neste capítulo são apresesentadas as considerações acerca dos pontos desenvolvidos durante o presente trabalho e apontamentos que desde já vislumbramos para trabalhos que possam dar continuidade à pesquisa realizada.

\subsection{Conclusões}

A pesquisa realizada tem como resultado a proposição de um grafo sensório-motor que se organiza exclusivamente com base na observação das modificações dos estados sensórios e motores percebidos. O grafo resultante representa a expansão temporal das relações causais determinísticas entre os estados sensórios e os caminhos possíveis gerados pelos estados motores.

O grafo proposto representa os primeiros passos para o estudo do desenvolvimento artificial autônomo da noção de objeto. Como mostrado na Seção 3, o modelo teórico vislubrado durante a pesquisa possui 5 níveis de desenvolvimento até chegar no que Piaget chama de esquemas móveis. Durante a pesquisa foram apenas desenvolvidos os dois primeiros níveis chegando à proposta de um modelo computacional para o esquema cognitivo apontado por Piaget. Os outros 3 níveis, a coordenação entre esquemas, a hierarquia de esquemas e os esquemas móveis foram apenas vislumbrados para permitir conceber as características de possíveis ambientes computacionais que possam se utilizar do modelo proposto.

A seguir são pontuadas algumas considerações sobre a pesquisa realizada. 


\section{- Domínio sensório-motor.}

A pesquisa sobre o modelo teórico do átomo de causalidade possibilitou a percepção de uma nova abordagem para a forma de conceber a relação básica que guia os modelos computacionais de esquema.

Ao invés da abordagem funcional utilizada pelos modelos tidos como base para

esta pesquisa, representada por: $C \stackrel{a}{\rightarrow} R$; foi proposta uma nova abordagem por domínio sensório-motor: $Q_{S} \stackrel{Q_{A}}{\rightarrow} Q_{O}$.

Tal mudança de abordagem tem como consequência a libertação do modelo em fazer uma única associação entre sensações e ações, permitindo que para cada situação sensória não apenas uma única ação seja proposta, mas sim um conjunto de ações $\left(Q_{A}\right)$. Note que esta mudança permite a conciliação das sugestões motoras advindas de mecanismos independentes simplesmente pela interseção dos conjuntos de ações sugeridas.

A abordagem por domínio sensório-motor é apresentada em artigo publicado (MUñOZ; NETTO, 2012).

\section{- Desenvolvimento Cognitivo Artificial Autônomo.}

O uso da teoria de Piaget como inspiração para o desenvolvimento de sistemas computacionais em conjunto com a percepção da relevância do problema de fundamentação simbólica na área de sistemas cognitivos levou às soluções de conduta estabelecidas pelo compromisso com a semântica nula e o paradigma do desenvolvimento mental autônomo. Estas duas condutas, apesar de não se contradizerem, têm focos distintos.

Como um dos frutos deste trabalho, visto as dificuldades em seguir tais condutas, surgiu o conceito de Desenvolvimento Cognitivo Artificial Autônomo. Este conceito é respaldado nesses quatro pilares e deverá se desenvolver ainda mais pelas experiências a serem adquiridas durante as tentativas de projetar mecanis- 
mos computacionais mais complexos e abstratos que estejam na direção da busca pelo desenvolvimento autônomo da noção de objeto.

\section{- Do objetivado ao autônomo.}

Uma das questões sobre a aplicação do construtivismo ${ }^{1}$ na área de inteligência computacional parece ser o uso de objetivos. Os sistemas tidos como base para esta pesquisa tendem a evitar criar mecanismo que se valham de algum objetivo para o seu desenvolvimento.

A conciliação entre mecanismos objetivados e o desenvolvimento autônomo exigido pelo construtivismo foi encontrada pela concepção de utilização entre mecanismos. O trabalho realizado mostrou que os mecanismos objetivados podem se enquadrar sob o DCAA desde que seus objetivos sejam internos ou possam ser gerados por outros mecanismos que componham o sistema. O principal exemplo é a utilização dos classificadores pelo grafo sensório-motor (GSM). Apesar dos classificadores se organizarem para encontrar classes com base em critérios externos, ao serem utilizados pelo GSM, capaz de designar estes critérios, os classificadores passam a compor o sistema sem dependências externas a este. Note que o próprio GSM é objetivado, pois se organiza tendo como critério seu objetivo sensório. Este deve então ser designado por outros mecanismos do sistema.

\section{- Instrumentalização entre os mecanismos.}

A concepção de sistemas cognitivos passa da utilização de um único mecanismo que rege todo o sistema para o uso de mecanismos distintos com incumbências específicas. Assim, a autonomia do desenvolvimento do sistema como um todo levanta a questão de como o acoplamento entre os mecanismos que compõem o sistema é realizado. Pode-se pensar em um sistema com mecanismos acoplados desde o projeto computacional, ou em um sistema onde o próprio acoplamento

\footnotetext{
${ }^{1} \mathrm{O}$ construtivismo tem como base a teoria de Piaget.
} 
se dê durante seu desenvolvimento. A primeira premissa parece estar contrária ao desenvolvimento realmente autônomo do sistema. No trabalho realizado se optou pela segunda alternativa.

Durante a pesquisa, ao pensar em sistemas onde os mecanismos não são acoplados em seu projeto, mas sim durante seu desenvolvimento, as questões do $q u \hat{e}$ deveria ser acoplado e de como este acoplamento poderia se dar se fizeram presentes.

A solução encontrada sobre o quê acoplar foi a de acoplar desde o projeto as estruturas a serem utilizadas pelos mecanismos deixando suas organizações a cargo do desenvolvimento. Estas decisões se refletem no trabalho tanto nos mecanismos de classificação quanto no GSM. Ambos mecanismos têm como estrutura subjacente a mesma rede neural cuja estrutura é predeterminada. Note que, por projeto, os classificadores são iniciados com uma rede neural com um número sobre-estimado de elementos na camada oculta e os GSMs, com um número sobre-estimado na camada de saída. Note também que tanto os classificadores quanto os GSMs se desenvolvem pela organização destas estruturas alocando seus elementos conforme suas necessidades. Perceba ainda que os classificadores são recrutados pelos GSMs.

Já a solução encontrada a cerca do como acoplar os mecanismos levou à adoção de regras com relação à autonomia do estabelecimento dos parâmetros utilizados para ajustar os mecanismos às suas incumbências. Os parâmetros utilizados pelos mecanismos são mantidos constantes ou dinamicamente modificados por retorno das próprias dinâmicas do mecanismo.

\section{- Paralelismo das estruturas.}

Já pensando na complexidade e dimensão de um futuro sistema cognitivo que se utilize dos mecanismos propostos, um fator que se evidencia é o da escalabilidade do esforço computacional por eles exigido. Não só os mecanismos pro- 
postos têm como base uma estrutura neural artificial, mas também os algoritmos utilizados foram concebidos de forma a permitirem um alto grau de paralelização.

- Comportamentos simples e descentralizados.

Os modelos teóricos propostos e as implementações resultantes foram concebidos primando pela modularização dos mecanismos, com atenção especial sobre as formas necessárias e possíveis ao estabelecimento de suas relações e interações. Mesmo dentro dos próprios mecanismos se optou por comportamentos mais simples e descentralizados. Após a finalização do trabalho se pôde perceber as seguintes consequências geradas por esta opção:

- O algoritmo utilizado para a adaptação da estrutura da rede neural utilizada como substrato para os mecanismos propostos é tido como um comportamento à parte de todo sistema. O algoritmo de backpropagation foi utilizado como exemplo de possíveis forma de adaptação da estrutura neural à suas finalidades, mas qualquer outro algoritmo pode ser utilizado pelo sistema proposto.

- O mecanismo de energia utilizado se fêz necessário à formulação dos mecanismos propostos. Este comportamento associado à abstração de energia se mostrou fundamental para o estabelecimento das coordenações entre as unidades básicas que compõem os mecanismos se postando como um átomo comportamental.

- Complexidade dos experimentos.

A observação do comportamento dos mecanismos propostos se mostrou extremamente complexa. Os seguintes fatores corroboram para a natureza da complexidade do sistema: 
1. A complexidade e tamanho das próprias estruturas geradas pela autonomia que o sistema tem para se desenvolver;

2. A natureza interativa do sistema com seu entorno (ambiente externo) no qual está imerso;

3. As dimensões dos domínios sensoriais e motores necessários para a percepção de atividades com modificação do entorno suficiente à nossa percepção.

\subsection{Trabalhos futuros}

Nesta seção trataremos de alguns pontos considerados importantes que foram percebidos ao longo desta pesquisa, mas que por não estarem no foco do trabalho proposto serão apontados como trabalhos futuros.

- Busca pelo desenvolvimento autônomo da noção de objeto.

O trabalho apresentado representa o início de um projeto de pesquisa muito mais amplo. Conjecturas sobre um possível caminho a ser trilhado na busca pela noção de objeto foram apontados na Seção 3.

A organização das estruturas sensório-motoras realizada pelo mecanismo de esquema proposto estão restritas ao seu domínio sensório-motor. A dimensão deste domínio diz sobre a dificuldade que o mecanismo que implementa o esquema tem para se estabilizar. A escalabilidade referente à dimensão do domínio não é vista como tarefa dos mecanismo que constituem o esquema mas sim delegada ao mecanismo de coordenação entre esquemas. Este mecanismo visa a utilização das organizações locais realizadas pelos esquemas para abrangência de todo o domínio sensório-motor do agente.

Assim como a coordenação entre esquemas amplia a utilização dos esquemas no aspecto sensório-motor, a hieraquia de esquemas pode condensar a apropriação das relações já estabelecidas, consolidando o aparato sensório-motor. 
Outros conceitos pensados por Piaget como o das reações circulares primárias e reações circulares secundárias devem ser pensados tendo como base os mecanismos apresentados neste trabalho.

- Sugestão de ações.

Note que o grafo sensório-motor (GSM) proposto não é utilizado para gerar ações que modifiquem o meio. As ações realizadas pelo agente são geradas aleatoriamente e bastam para que o GSM proposto se organize.

A escolha das ações de um agente que se utilize do modelo proposto não são vistas como incumbência do GSM, mas de outro mecanismo mais amplo. O GSM tem o papel de possibilitar a consulta sobre o que pode ser feito para atingir um dado objetivo e não um papel ditatorial sobre o que deve ser efetuado.

\section{- A topologia do aparato sensório-motor.}

A topologia tanto dos sensores quanto dos atuadores do agente parece ter fundamental importância, principalmente quando se pensa em esquemas que estarão utilizando apenas subconjuntos destes espaços. Apesar da premissa de semântica nula, a forma de organizar o aparato sensório-motor sem compromisso semântico se apresenta como um assunto interessante para estudos futuros.

- A granularidade temporal.

Durante o trabalho, pode ser percebida a influência da granularidade temporal para a constituição das estruturas internas geradas pelo GSM. O mundo capaz de ser captado pelo sistema e que regrará as estruturas dos mecanismos está intrinsecamente associado ao menor tempo possível de ser percebido pelos átomos de causalidade. A relação entre os possíveis padrões de grafos cognitivos com tempos distintos de percepção causal merece ser mais detalhadamente estudado.

- A separação da representação espaço-temporal. 
O modelo proposto só foi possível a partir da concepção unificada dos domínios sensório e motor. Também, implicitamente, o domínio temporal foi fundido pela concepção do átomo de causalidade.

Apesar de fundamental para o estabelecimento das coerências entre o sistema e o ambiente que o circunda, o determinismo imposto pelo uso do átomo de causalidade é apenas semente para a organização das estruturas internas do GSM. Merecem especial atenção as possibilidades de utilização das estruturas internas dos GSMs para ressaltar aspectos cognitivos associados à organização das relações, do mundo externo, com relação aos conceitos de espaço, tempo e, principalmente, da noção de objeto. 


\section{REFERÊNCIAS}

CHAPUT, H.; KUIPERS, B.; MIIKKULAINEN, R. Constructivist learning: A neural implementation of the schema mechanism. In: Proceedings of the Workshop on SelfOrganizing Maps. Kitakyushu, Japan: WSOM03, 2003.

CHAUVIN, Y. A back-propagation algorithm with optimal use of hidden units. In: Advances in Neural Information Processing Systems 1. San Mateo, CA, USA: Morgan Kaufmann Publishers, 1989. p. 519-526. D. S. Touretzky, Ed.

DRESCHER, G. L. Made-Up Minds: A Constructivist Approach to Artificial Intelligence. Cambridge, MA, US: The MIT Press, 1991.

FAHLMAN, S. E. The recurrent cascade-correlation architecture. In: Advances In Neural Information Processing Systems 3. [S.1.]: Morgan Kaufmann Publishers Inc., 1990. p. 190-196.

FAHLMAN, S. E.; LEBIERE, C. The cascade-correlation learning architecture. In: Advances in Neural Information Processing Systems 2. [S.1.]: Morgan Kaufmann, 1990. p. 524-532.

GLäSER, C.; JOUBLIN, F.; GOERICK, C. Learning and use of sensorimotor schemata maps. In: IEEE 8th International Conference on Development and Learning. Shanghai, China: IEEE Computer Society, 2009.

HARNAD, S. The symbol grounding problem. In: Encyclopedia of Cognitive Science. London, UK: Nature Publishing Group/Macmillan, 2003.

HOLMES, M.; ISBELL, C. Schema learning: Experience-based construction of predictive action models. Advances in Neural Information Processing Systems, v. 17, 2005.

KANT, I. Crítica da Razão Pura. 5. ed. Lisboa, PT: Fundação Calouste Gulbenkian (2001), 1781. Tradução de Manuela Pinto dos Santos e Alexandre Fradique Morujão.

KURKOVA, V. Kolmogorov's theorem and multilayer neural networks. Neural Networks, v. 5, p. 501-506, 1992.

LICHMAN, M. UCI Machine Learning Repository. 2013. Disponível em: $<$ http://archive.ics.uci.edu/ml $>$.

LITTMANN, E.; RITTER, H. Cascade network architectures. In: in Proc. Intern. Joint Conference On Neural Networks. [S.1.: s.n.], 1992. p. 398-404. 
MUñOZ, M. E. S.; NETTO, M. L. Sensorimotor domain approach for artificial autonomous cognitive development. In: SBIA 2012, LNAI 7589. Curitiba, PR, BR: Springer-Verlag Berlin Heidelberg, 2012. p. 22-31.

PEROTTO, F. S.; BUISSON, J. C.; ALVARES, L. O. Constructivist anticipatory learning mechanism (CALM) - dealing with partially deterministic and partially observable environments. In: Proc. of the 7th Int. Conf. on Epigenetic Robotics: Modeling Cognitive Development in Robotic Systems. Lund University Cognitive Studies, 135: Lund: LUCS, 2007.

PIAGET, J. O Nascimento da Inteligência na Criança. Lisboa, PT: Publicações Dom Quixote (1986), 1936. 1937.

. A Construção do Real na Criança. 3. ed. Lisboa, PT: Editora Ática (1996),

. A Formação do Símbolo na Criança: imitação, jogo e sonho, imagem e representação. 3. ed. Rio de Janeiro, BR: Livros Técnicos e Científicos Editora (1990), 1964.

. O Desenvolvimento do Pensamento - Equilibração das Estruturas Cognitivas. 1. ed. Lisboa, PT: Publicações Dom Quixote (1977), 1977.

REED, R. Pruning algorithms - a survey. IEEE Trans Neural Netw, v. 4, n. 5, p. 740-747, 1993.

TADDEO, M.; FLORIDI, L. Solving the symbol grounding problem: A critical review of fifteen years of research. Journal of Experimental and Theoretical Artificial Intelligence, v. 17, p. 419-445, 2005.

TANI, J.; ITO, M.; SUGITA, Y. Self-organization of distributedly represented multiple behavior schemata in a mirror system: reviews of robot experiments using RNNPB. Neural Network, v. 17, p. 1273-1289, 2004.

TANIGUCHI, T.; SAWARAGI, T. Incremental acquisition of multiple nonlinear forward models based on di erentiation process of schema model. Neural Network, v. 21, n. 1, p. 13-27, 2008.

WAZLAWICK, R. Um Modelo Operatório para Construção de Conhecimento. Tese (Doutorado) - Universidade Federal de Santa Catarina, Florianópolis, SC, BR, 1993.

WENG, J.; MCCLELLAND, J. L.; PENTLAND, A. Autonomous mental development by robots and animals. Science, v. 291, n. 5504, p. 599-600, Fev 2006.

WILLIAMS, M. et al. A grounding framework. Autonomous Agents and Multi-Agent Systems, v. 19, n. 3, p. 272-296, Dez 2009.

WOLPERT, D.; KAWATO, M. Multiple paired forward and inverse models for motor control. Neural Network, v. 11, p. 1317-1329, 1998.

YAVUZ, A.; DAVENPORT, D. PAL: A constructivist model of cognitive activity. In: Proc. Int. Conf. on New Trends in Cognitive Science: Does Representation Need Reality? Viena, Austria: ASoCS, 1997. 